\title{
Cigarette Use Among High School Students — United States, 1991-2009
}

Understanding the trends in the prevalence of cigarette smoking among youths enables policy makers to target prevention resources more effectively. Every 2 years, CDC analyzes data from the national Youth Risk Behavior Survey (YRBS) to evaluate trends in cigarette use among high school students in the United States. This report updates a previous report (1) and describes results of CDC's 2010 analysis of YRBS data from 1991-2009 for three measures: ever smoked cigarettes, current cigarette use, and current frequent cigarette use. For ever smoked cigarettes, the prevalence did not change from 1991 (70.1\%) to 1999 (70.4\%), declined to $58.4 \%$ in 2003, and then declined more gradually, to $46.3 \%$ in 2009 . For current cigarette use, the prevalence increased from $27.5 \%$ in 1991 to $36.4 \%$ in 1997 , declined to $21.9 \%$ in 2003 , and then declined more gradually, to $19.5 \%$ in 2009 . For current frequent cigarette use, the prevalence increased from $12.7 \%$ in 1991 to $16.8 \%$ in 1999 , declined to $9.7 \%$ in 2003 , and then declined more gradually, to $7.3 \%$ in 2009 . For all three measures, rates began to decline in the late 1990s, but the rate of decline slowed during 2003-2009. To increase the rate of decline in cigarette use among high school students, reductions in advertising, promotions, and commercial availability of tobacco products should be combined with full implementation of communitywide, comprehensive tobacco control programs (2-5).

The biennial national YRBS, a component of CDC's Youth Risk Behavior Surveillance System, used independent, threestage cluster samples for the 1991-2009 surveys to obtain cross-sectional data representative of public and private school students in grades 9-12 in all 50 states and the District of Columbia.* For each survey, students completed anonymous, self-administered questionnaires that included identically worded questions about cigarette use. During 1991-2009, the number of participating schools ranged from 110 to 159 , and the number of participating students ranged from 10,904 to 16,410. School response rates ranged from $70 \%$ to $81 \%$, stu-

* Additional information available at http://www.cdc.gov/healthyyouth/yrbs/yrbs_ methods.htm. dent response rates ranged from $83 \%$ to $90 \%$, and the overall response rates ranged from $60 \%$ to $71 \%$.

For this analysis, ever smoked cigarettes was defined as ever trying cigarette smoking, even one or two puffs; current cigarette use was defined as smoking cigarettes on at least 1 day during the 30 days before the survey; and current frequent cigarette use was defined as smoking cigarettes on 20 or more days during the 30 days before the survey. Race/ethnicity data were analyzed only for non-Hispanic black, non-Hispanic white, and Hispanic students (who might be of any race); the numbers of students from other racial/ethnic groups were too small for meaningful analysis. Data were weighted to provide national estimates, and the statistical software used for all data analyses accounted for the complex sample design. Temporal changes were analyzed using logistic regression analyses, which controlled for sex, race/ethnicity, and grade and simultaneously assessed linear, quadratic, and cubic time effects $(\mathrm{p}<0.05) .^{\dagger}$

Significant linear, quadratic, and cubic effects were detected for all three measures (Table 1 and Figure 1). The percentage of students who ever smoked cigarettes did not change from

\footnotetext{
$\dagger^{\dagger}$ uadratic and cubic trends indicate a significant but nonlinear trend in the data over time (e.g., whereas a linear trend is depicted with a straight line, a quadratic trend is depicted with a curve with one bend and a cubic trend with a curve with two bends). Trends that include significant cubic or quadratic and linear components demonstrate nonlinear variation in addition to an overall increase or decrease over time.
}

\section{INSIDE}

802 Progress Toward Poliomyelitis Eradication - Nigeria, January 2009-June 2010

808 Vital Signs: Colorectal Cancer Screening Among Adults Aged 50-75 Years - United States, 2008

813 Vital Signs: Breast Cancer Screening Among Women Aged 50-74 Years — United States, 2008

817 Notes from the Field

818 Announcement

819 QuickStats

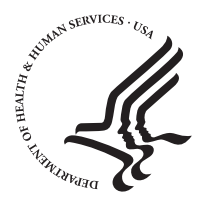

U.S. DEPARTMENT OF HEALTH AND HUMAN SERVICES Centers for Disease Control and Prevention www.cdc.gov/mmwr

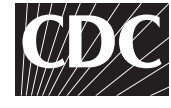


$1991(70.1 \%)$ to 1999 (70.4\%), declined to $58.4 \%$ in 2003 , and then declined more gradually to $46.3 \%$ in 2009. The percentage of students who reported current cigarette use increased from $27.5 \%$ in 1991 to $36.4 \%$ in 1997 , declined to $21.9 \%$ in 2003 , and declined more gradually to $19.5 \%$ in 2009 . The percentage of students who reported current frequent cigarette use increased from $12.7 \%$ in 1991 to $16.8 \%$ in 1999 , declined to $9.7 \%$ in 2003 , and then declined more gradually to $7.3 \%$ in 2009 .

For current cigarette use, trend analyses were conducted by sex, race/ethnicity, and grade in school (Figures 2 and 3). Significant linear, quadratic, and cubic effects similar to the overall analysis were observed for current cigarette use among female students overall, white female students, black students overall, black male students, 9th-grade students, and 10th-grade students (Table 2). Among male students overall, white students overall, white male students, Hispanic male students, and 11th-grade students, current cigarette use increased from 1991 to 1997, declined from 1997 to 2003, and then remained stable. Among Hispanic students overall and Hispanic female students, current cigarette use increased from 1991 to 1995 , declined from 1995 to 2003, and then remained stable. Among 12th-grade students, current cigarette use increased from 1991 to 1999 , declined from 1999 to 2003, and then remained stable. Among black female students, only linear and quadratic effects were observed, indicating that the prevalence of current cigarette use increased from 1991 to 1999 and then declined, with no slowing or leveling off.

\section{Reported by}

Office on Smoking and Health, Div of Adolescent and School Health, National Center for Chronic Disease Prevention and Health Promotion, CDC.

\section{Editorial Note}

The findings in this report show that for three measures of cigarette use (ever smoked cigarettes, current cigarette use, and current frequent cigarette use), rates among high school students began to decline in the late 1990s, but the rate of decline slowed during 2003-2009. These trends are consistent with trends for 30-day and daily cigarette use reported from the Monitoring the Future survey (an ongoing national study of the behaviors, attitudes, and values of 8th-, 10th- , and 12th-grade students), which also showed declines starting in the late 1990s but gradual declines most recently (G). As a result of the slow declines in youth smoking described in this report, the Healthy

The MMWR series of publications is published by the Office of Surveillance, Epidemiology, and Laboratory Services, Centers for Disease Control and Prevention (CDC), U.S. Department of Health and Human Services, Atlanta, GA 30333.

Suggested citation: Centers for Disease Control and Prevention. [Article title]. MMWR 2010;59:[inclusive page numbers].

\section{Centers for Disease Control and Prevention \\ Thomas R. Frieden, MD, MPH, Director \\ Harold W. Jaffe, MD, MA, Associate Director for Science \\ James W. Stephens, PhD, Office of the Associate Director for Science}

Stephen B. Thacker, MD, MSc, Deputy Director for Surveillance, Epidemiology, and Laboratory Services

MMWR Editorial and Production Staff

Frederic E. Shaw, MD, JD, Editor, MMWR Series

Christine G. Casey, MD, Deputy Editor, MMWR Series

Robert A. Gunn, MD, MPH, Associate Editor, MMWR Series

Teresa F. Rutledge, Managing Editor, MMWR Series

Douglas W. Weatherwax, Lead Technical Writer-Editor

Donald G. Meadows, MA, Jude C. Rutledge, Writer-Editors
Martha F. Boyd, Lead Visual Information Specialist Malbea A. LaPete, Stephen R. Spriggs, Terraye M. Starr Visual Information Specialists

Quang M. Doan, MBA, Phyllis H. King Information Technology Specialists

MMWR Editorial Board

William L. Roper, MD, MPH, Chapel Hill, NC, Chairman

Virginia A. Caine, MD, Indianapolis, IN

Jonathan E. Fielding, MD, MPH, MBA, Los Angeles, CA David W. Fleming, MD, Seattle, WA

William E. Halperin, MD, DrPH, MPH, Newark, NJ

King K. Holmes, MD, PhD, Seattle, WA

Deborah Holtzman, PhD, Atlanta, GA

John K. Iglehart, Bethesda, MD

Dennis G. Maki, MD, Madison, WI
Patricia Quinlisk, MD, MPH, Des Moines, IA

Patrick L. Remington, MD, MPH, Madison, WI

Barbara K. Rimer, DrPH, Chapel Hill, NC John V. Rullan, MD, MPH, San Juan, PR

William Schaffner, MD, Nashville, TN Anne Schuchat, MD, Atlanta, GA

Dixie E. Snider, MD, MPH, Atlanta, GA John W. Ward, MD, Atlanta, GA 
TABLE 1. Percentage of high school students who had ever smoked cigarettes, ${ }^{*}$ were current cigarette users, ${ }^{\dagger}$ and were current frequent cigarette users ${ }^{\S}$ - Youth Risk Behavior Survey, United States, 1991-2009ף

\begin{tabular}{|c|c|c|c|c|c|c|c|c|c|c|}
\hline & 1991 & 1993 & 1995 & 1997 & 1999 & 2001 & 2003 & 2005 & 2007 & 2009 \\
\hline Category & $\begin{array}{c}\% \\
\left(95 \% \mathrm{Cl}^{* *}\right)\end{array}$ & $\begin{array}{c}\% \\
(95 \% \mathrm{Cl})\end{array}$ & $\begin{array}{c}\% \\
(95 \% \mathrm{Cl})\end{array}$ & $\begin{array}{c}\% \\
(95 \% \mathrm{Cl})\end{array}$ & $\begin{array}{c}\% \\
(95 \% \mathrm{Cl})\end{array}$ & $\begin{array}{c}\% \\
(95 \% \mathrm{Cl})\end{array}$ & $\begin{array}{c}\% \\
(95 \% \mathrm{Cl})\end{array}$ & $\begin{array}{c}\% \\
(95 \% \mathrm{Cl})\end{array}$ & $\begin{array}{c}\% \\
(95 \% \mathrm{Cl})\end{array}$ & $\begin{array}{c}\% \\
(95 \% \mathrm{Cl})\end{array}$ \\
\hline Ever smoked cigarettes ${ }^{\dagger \dagger}$ & $\begin{array}{c}70.1 \\
(67.8-72.3)\end{array}$ & $\begin{array}{c}69.5 \\
(68.1-70.8)\end{array}$ & $\begin{array}{c}71.3 \\
(69.5-73.0)\end{array}$ & $\begin{array}{c}70.2 \\
(68.2-72.1)\end{array}$ & $\begin{array}{c}70.4 \\
(67.3-73.3)\end{array}$ & $\begin{array}{c}63.9 \\
(61.6-66.0)\end{array}$ & $\begin{array}{c}58.4 \\
(55.1-61.6)\end{array}$ & $\begin{array}{c}54.3 \\
(51.2-57.3)\end{array}$ & $\begin{array}{c}50.3 \\
(47.2-53.5)\end{array}$ & $\begin{array}{c}46.3 \\
(43.7-48.9)\end{array}$ \\
\hline Current cigarette use $^{t \dagger}$ & $\begin{array}{c}27.5 \\
(24.8-30.3)\end{array}$ & $\begin{array}{c}30.5 \\
(28.6-32.4)\end{array}$ & $\begin{array}{c}34.8 \\
(32.5-37.2)\end{array}$ & $\begin{array}{c}36.4 \\
(34.1-38.7)\end{array}$ & $\begin{array}{c}34.8 \\
(32.3-37.4)\end{array}$ & $\begin{array}{c}28.5 \\
(26.4-30.6)\end{array}$ & $\begin{array}{c}21.9 \\
(19.8-24.2)\end{array}$ & $\begin{array}{c}23.0 \\
(20.7-25.5)\end{array}$ & $\begin{array}{c}20.0 \\
(17.6-22.6)\end{array}$ & $\begin{array}{c}19.5 \\
(17.9-21.2)\end{array}$ \\
\hline Current frequent cigarette use ${ }^{\dagger \dagger}$ & $\begin{array}{c}12.7 \\
(10.6-15.3)\end{array}$ & $\begin{array}{c}13.8 \\
(12.1-15.5)\end{array}$ & $\begin{array}{c}16.1 \\
(13.6-19.1)\end{array}$ & $\begin{array}{c}16.7 \\
(14.8-18.7)\end{array}$ & $\begin{array}{c}16.8 \\
(14.3-19.6)\end{array}$ & $\begin{array}{c}13.8 \\
(12.3-15.5)\end{array}$ & $\begin{array}{c}9.7 \\
(8.3-11.3)\end{array}$ & $\begin{array}{c}9.4 \\
(7.9-11.0)\end{array}$ & $\begin{array}{c}8.1 \\
(6.7-9.8)\end{array}$ & $\begin{array}{c}7.3 \\
(6.4-8.3)\end{array}$ \\
\hline
\end{tabular}

* Ever tried cigarette smoking, even one or two puffs.

† Smoked cigarettes on at least 1 day during the 30 days before the survey.

$\S$ Smoked cigarettes on 20 or more days during the 30 days before the survey.

I Linear, quadratic, and cubic trend analyses were conducted using a logistic regression model controlling for sex, race/ethnicity, and grade.

** Confidence interval.

${ }^{+\dagger}$ Significant linear, quadratic, and cubic effects were detected $(p<0.05)$.

People 2010 national health objective to reduce the prevalence of current cigarette use among high school students to $\leq 16 \% \$$ has not been met.

The findings in this report also show that since 2003 the rate of decline in current cigarette use slowed or leveled off for all racial/ethnic and sex subgroups except black female students, for which no slowing or leveling off occurred in the rate of decline after 1999. Cigarette smoking rates reflect complex and interrelated individual, social, and environmental factors $(4,7)$. More detailed research is needed to explain why current cigarette use during 2003-2009 declined more slowly among some racial/ethnic and sex subgroups of high school students but remained stable among others.

The impact of tobacco advertising and promotion activities on youth smoking initiation has been documented previously (8). The increase in current cigarette use among high school students during the early to mid-1990s observed in this and other surveys might have resulted from expanded tobacco company promotional efforts, including discounted prices on cigarette brands most often smoked by adolescents, depictions of tobacco use in movies, distribution of nontobacco products with company symbols (e.g., hats and T-shirts), and sponsorship of music concerts and other youth-focused events ( 7 ). Reductions in advertising, promotions, and commercial availability of tobacco products should be combined with expanded counter-advertising mass media campaigns and implemented with other well-documented and effective strategies (e.g., higher prices for tobacco products through increases in excise taxes, tobacco-

$\$$ Additional information available at http://www.healthypeople.gov/ document/pdf/volume2/27tobacco.pdf.
FIGURE 1. Percentage of high school students who had ever smoked cigarettes,* were current cigarette users, ${ }^{\dagger}$ and were current frequent cigarette users ${ }^{\S}-$ Youth Risk Behavior Survey, United States, 1991-2009

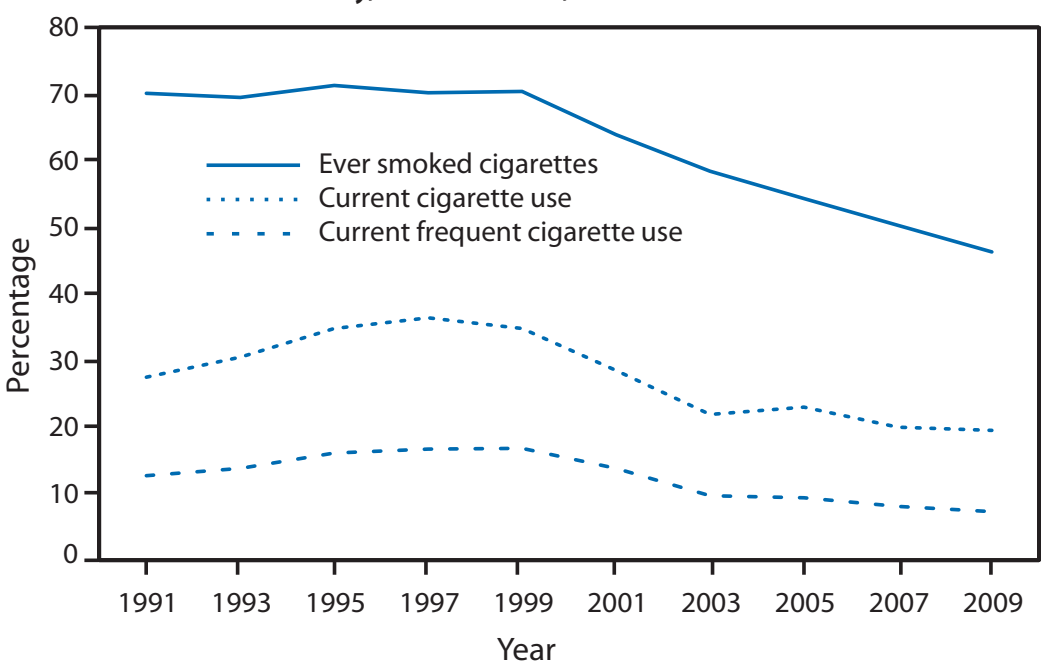

* Ever tried cigarette smoking, even one or two puffs.

† Smoked cigarettes on at least 1 day during the 30 days before the survey.

$\S$ Smoked cigarettes on 20 or more days during the 30 days before the survey.

free environments, programs that promote changes in social norms, and comprehensive communitywide and school-based tobacco-use prevention policies)(2-5).

The findings in this report are subject to at least two limitations. First, these data apply only to youths who attend school and, therefore, are not representative of all persons in this age group. Nationwide, in 2007, of persons aged 16-17 years, approximately 4\% were not enrolled in a high school program and had not completed high school (9). Second, the extent of underreporting or overreporting of cigarette use cannot be determined, although the survey questions demonstrate good test-retest reliability (10). 
FIGURE 2. Percentage of high school students who were current cigarette users, ${ }^{*}$ by sex and race/ethnicity - Youth Risk Behavior Survey, United States, 1991-2009

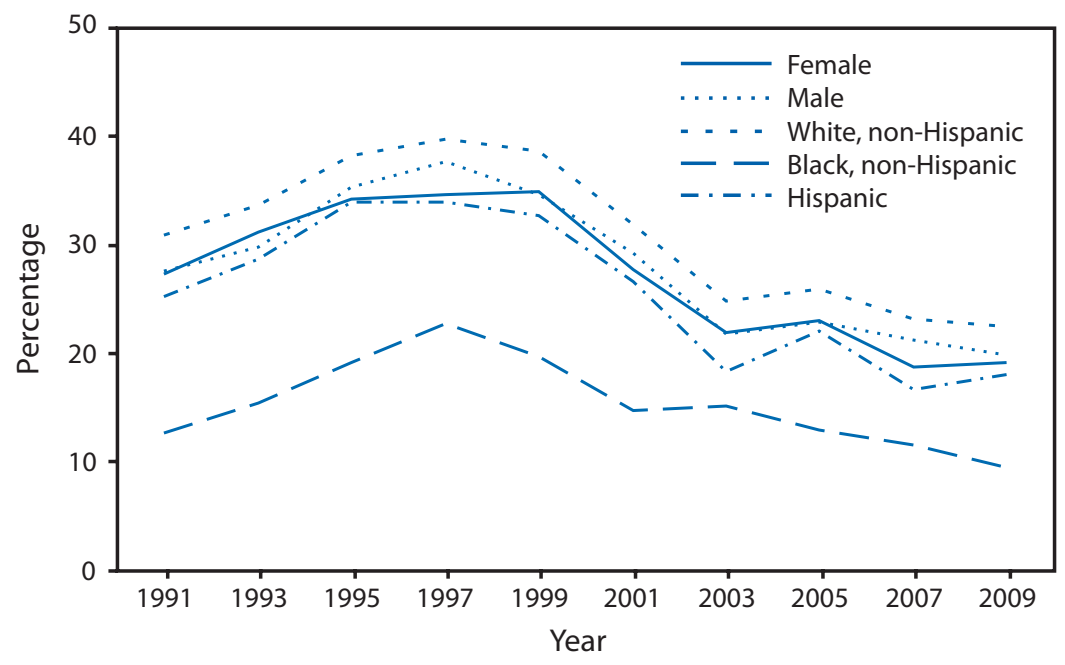

* Smoked cigarettes on at least 1 day during the 30 days before the survey.

FIGURE 3. Percentage of high school students who were current cigarette users,* by grade - Youth Risk Behavior Survey, United States, 1991-2009

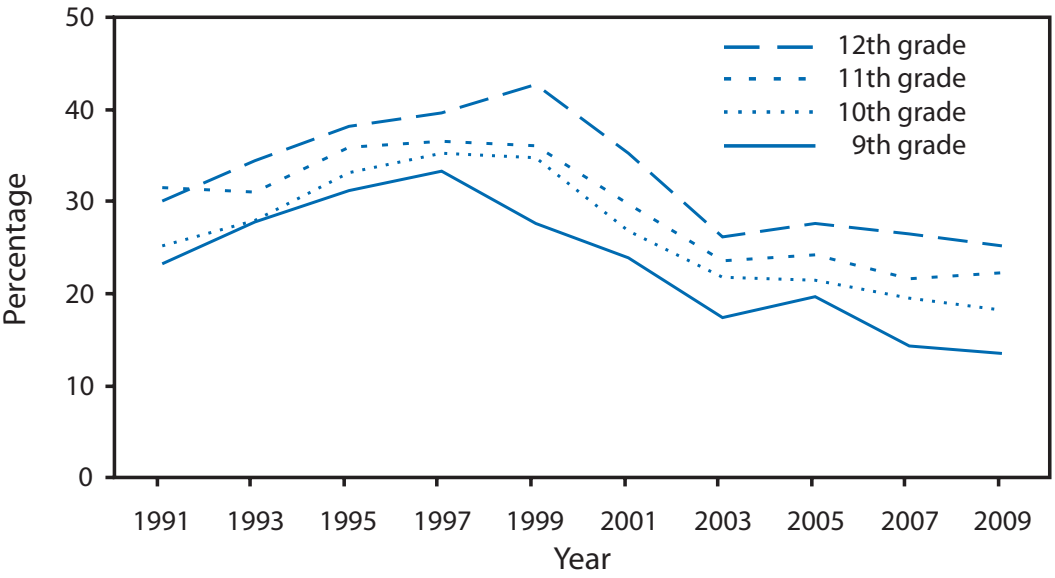

* Smoked cigarettes on at least 1 day during the 30 days before the survey.

\section{What is already known on this topic?}

National data show that the prevalence of cigarette use among youths began to decline in the late 1990s.

What is added by this report?

The findings in this report show that for three measures of cigarette use (ever smoked cigarettes, current cigarette use, and current frequent cigarette use), rates among high school students began to decline in the late 1990s, but the rate of decline slowed during 2003-2009.

What are the implications for public health practice? To reduce the adverse health consequences associated with tobacco use, the most effective evidencebased strategies to reduce initiation of tobacco use among youths should be implemented nationwide, including higher prices for tobacco products, tobacco-free environment policies, and counteradvertising mass media campaigns.

The Family Smoking Prevention and Tobacco Control Act (Tobacco Control Act), 9 enacted in 2009, provides new opportunities for broad scale reductions in tobacco use. This statute gives the Food and Drug Administration (FDA) additional authority to regulate the tobacco industry. The Act imposes specific marketing, labeling, and advertising requirements, and establishes restrictions on youth access and promotional practices that are particularly attractive to youth. The provisions of the Act offer opportunities for FDA to work as a partner in tobacco prevention and control (e.g., through collaborations with CDC and other federal and state agencies) (5). As suggested by the Institute of Medicine, the regulation of tobacco products is an important component of a comprehensive national tobacco prevention and control strategy that will complement and strengthen the impact of traditional, evidence-based interventions (4).

\footnotetext{
Family Smoking Prevention and Tobacco Control Act, Pub. L. No.111-31, 123 Stat 1776 (2009). Additional information available at http://www.gpo.gov/fdsys/pkg/PLAW-111 publ31/content-detail. html.
} 
TABLE 2. Percentage of high school students who were current cigarette users, ${ }^{*}$ by sex, race/ethnicity, and grade — Youth Risk Behavior Survey, United States, 1991-2009 ${ }^{\dagger}$

\begin{tabular}{|c|c|c|c|c|c|c|c|c|c|c|}
\hline Characteristic & $\frac{1991}{\%}$ & $\frac{1993}{\%}$ & $\begin{array}{c}1995 \\
\% \\
(95 \% \mathrm{CI})\end{array}$ & $\begin{array}{c}1997 \\
\% \\
(95 \% \mathrm{CI})\end{array}$ & $\begin{array}{c}1999 \\
\% \\
(95 \% \mathrm{Cl})\end{array}$ & $\begin{array}{c}2001 \\
\% \\
(95 \% \mathrm{Cl})\end{array}$ & $\begin{array}{c}2003 \\
\% \\
(95 \% \mathrm{Cl})\end{array}$ & $\begin{array}{c}2005 \\
\% \\
(95 \% \mathrm{Cl})\end{array}$ & 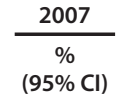 & $\begin{array}{c}2009 \\
\% \\
(95 \% \mathrm{Cl})\end{array}$ \\
\hline \multicolumn{11}{|l|}{ Sex } \\
\hline Female & $\begin{array}{c}27.3 \\
(23.9-31.0)\end{array}$ & $\begin{array}{c}31.2 \\
(29.1-33.4)\end{array}$ & $\begin{array}{c}34.3 \\
(31.0-37.7)\end{array}$ & $\begin{array}{c}34.7 \\
(31.8-37.6)\end{array}$ & $\begin{array}{c}34.9 \\
(32.3-37.7)\end{array}$ & $\begin{array}{c}27.7 \\
(25.6-30.0)\end{array}$ & $\begin{array}{c}21.9 \\
(19.2-24.9)\end{array}$ & $\begin{array}{c}23.0 \\
(20.4-25.8)\end{array}$ & $\begin{array}{c}18.7 \\
(16.5-21.1)\end{array}$ & $\begin{array}{c}19.1 \\
(17.2-21.0)\end{array}$ \\
\hline Male & $\begin{array}{c}27.6 \\
(24.6-30.9)\end{array}$ & $\begin{array}{c}29.8 \\
(27.4-32.3)\end{array}$ & $\begin{array}{c}35.4 \\
(32.9-37.9)\end{array}$ & $\begin{array}{c}37.7 \\
(35.0-40.6)\end{array}$ & $\begin{array}{c}34.7 \\
(31.8-37.7)\end{array}$ & $\begin{array}{c}29.2 \\
(26.7-32.0)\end{array}$ & $\begin{array}{c}21.8 \\
(19.8-24.1)\end{array}$ & $\begin{array}{c}22.9 \\
(20.7-25.3)\end{array}$ & $\begin{array}{c}21.3 \\
(18.3-24.6)\end{array}$ & $\begin{array}{c}19.8 \\
(17.8-21.9)\end{array}$ \\
\hline \multicolumn{11}{|l|}{ Race/Ethnicity** } \\
\hline White, non-Hispanic & $\begin{array}{c}30.9 \\
(27.6-34.5)\end{array}$ & $\begin{array}{c}33.7 \\
(31.4-36.0)\end{array}$ & $\begin{array}{c}38.3 \\
(35.6-41.1)\end{array}$ & $\begin{array}{c}39.7 \\
(37.3-42.2)\end{array}$ & $\begin{array}{c}38.6 \\
(35.5-41.9)\end{array}$ & $\begin{array}{c}31.9 \\
(29.6-34.4)\end{array}$ & $\begin{array}{c}24.9 \\
(22.4-27.5)\end{array}$ & $\begin{array}{c}25.9 \\
(22.9-29.2)\end{array}$ & $\begin{array}{c}23.2 \\
(20.4-26.2)\end{array}$ & $\begin{array}{c}22.5 \\
(20.0-25.2)\end{array}$ \\
\hline Female & $\begin{array}{c}31.7 \\
(27.1-36.7)\end{array}$ & $\begin{array}{c}35.3 \\
(32.6-38.0)\end{array}$ & $\begin{array}{c}39.8 \\
(36.3-43.5)\end{array}$ & $\begin{array}{c}39.9 \\
(36.6-43.2)\end{array}$ & $\begin{array}{c}39.1 \\
(35.4-42.9)\end{array}$ & $\begin{array}{c}31.2 \\
(28.7-33.7)\end{array}$ & $\begin{array}{c}26.6 \\
(23.0-30.5)\end{array}$ & $\begin{array}{c}27.0 \\
(23.4-31.0)\end{array}$ & $\begin{array}{c}22.5 \\
(19.6-25.7)\end{array}$ & $\begin{array}{c}22.8 \\
(20.3-25.5)\end{array}$ \\
\hline Maleף & $\begin{array}{c}30.2 \\
(26.5-34.3)\end{array}$ & $\begin{array}{c}32.2 \\
(29.4-35.0)\end{array}$ & $\begin{array}{c}37.0 \\
(33.7-40.5)\end{array}$ & $\begin{array}{c}39.6 \\
(35.8-43.5)\end{array}$ & $\begin{array}{c}38.2 \\
(34.6-41.8)\end{array}$ & $\begin{array}{c}32.7 \\
(29.7-35.9)\end{array}$ & $\begin{array}{c}23.3 \\
(20.7-26.0)\end{array}$ & $\begin{array}{c}24.9 \\
(22.2-27.7)\end{array}$ & $\begin{array}{c}23.8 \\
(20.2-27.8)\end{array}$ & $\begin{array}{c}22.3 \\
(18.9-26.0)\end{array}$ \\
\hline Black, non-Hispanic ${ }^{\Uparrow}$ & $\begin{array}{c}12.6 \\
(10.2-15.5)\end{array}$ & $\begin{array}{c}15.4 \\
(12.9-18.2)\end{array}$ & $\begin{array}{c}19.1 \\
(16.1-22.6)\end{array}$ & $\begin{array}{c}22.7 \\
(19.0-26.8)\end{array}$ & $\begin{array}{c}19.7 \\
(15.8-24.3)\end{array}$ & $\begin{array}{c}14.7 \\
(12.0-17.9)\end{array}$ & $\begin{array}{c}15.1 \\
(12.4-18.2)\end{array}$ & $\begin{array}{c}12.9 \\
(11.1-14.8)\end{array}$ & $\begin{array}{c}11.6 \\
(9.5-14.1)\end{array}$ & $\begin{array}{c}9.5 \\
(8.2-11.1)\end{array}$ \\
\hline Female $^{\dagger \dagger}$ & $\begin{array}{c}11.3 \\
(9.2-13.9)\end{array}$ & $\begin{array}{c}14.4 \\
(11.9-17.4)\end{array}$ & $\begin{array}{c}12.2 \\
(9.3-15.7)\end{array}$ & $\begin{array}{c}17.4 \\
(13.8-21.7)\end{array}$ & $\begin{array}{c}17.7 \\
(14.4-21.7)\end{array}$ & $\begin{array}{c}13.3 \\
(10.1-17.2)\end{array}$ & $\begin{array}{c}10.8 \\
(8.2-14.2)\end{array}$ & $\begin{array}{c}11.9 \\
(10.2-13.8)\end{array}$ & $\begin{array}{c}8.4 \\
(6.6-10.6)\end{array}$ & $\begin{array}{c}8.4 \\
(6.5-10.9)\end{array}$ \\
\hline Maleף & $\begin{array}{c}14.1 \\
(10.1-19.4)\end{array}$ & $\begin{array}{c}16.3 \\
(12.4-21.1)\end{array}$ & $\begin{array}{c}27.8 \\
(22.5-33.9)\end{array}$ & $\begin{array}{c}28.2 \\
(23.0-34.1)\end{array}$ & $\begin{array}{c}21.8 \\
(15.4-29.9)\end{array}$ & $\begin{array}{c}16.3 \\
(13.2-19.8)\end{array}$ & $\begin{array}{c}19.3 \\
(15.8-23.5)\end{array}$ & $\begin{array}{c}14.0 \\
(11.5-16.9)\end{array}$ & $\begin{array}{c}14.9 \\
(11.7-18.8)\end{array}$ & $\begin{array}{c}10.7 \\
(8.4-13.5)\end{array}$ \\
\hline Hispanic & $\begin{array}{c}25.3 \\
(22.5-28.2)\end{array}$ & $\begin{array}{c}28.7 \\
(25.8-31.8)\end{array}$ & $\begin{array}{c}34.0 \\
(28.7-39.6)\end{array}$ & $\begin{array}{c}34.0 \\
(31.3-36.9)\end{array}$ & $\begin{array}{c}32.7 \\
(29.0-36.6)\end{array}$ & $\begin{array}{c}26.6 \\
(22.4-31.2)\end{array}$ & $\begin{array}{c}18.4 \\
(16.1-20.9)\end{array}$ & $\begin{array}{c}22.0 \\
(18.7-25.8)\end{array}$ & $\begin{array}{c}16.7 \\
(13.5-20.4)\end{array}$ & $\begin{array}{c}18.0 \\
(16.0-20.2)\end{array}$ \\
\hline Female & $\begin{array}{c}22.9 \\
(19.2-27.1)\end{array}$ & $\begin{array}{c}27.3 \\
(23.5-31.5)\end{array}$ & $\begin{array}{c}32.9 \\
(27.4-39.0)\end{array}$ & $\begin{array}{c}32.3 \\
(28.6-36.2)\end{array}$ & $\begin{array}{c}31.5 \\
(26.8-36.5)\end{array}$ & $\begin{array}{c}26.0 \\
(22.3-30.0)\end{array}$ & $\begin{array}{c}17.7 \\
(15.6-19.9)\end{array}$ & $\begin{array}{c}19.2 \\
(16.4-22.5)\end{array}$ & $\begin{array}{c}14.6 \\
(11.3-18.8)\end{array}$ & $\begin{array}{c}16.7 \\
(14.4-19.2)\end{array}$ \\
\hline Maleף & $\begin{array}{c}27.8 \\
(24.3-31.8)\end{array}$ & $\begin{array}{c}30.2 \\
(26.7-33.8)\end{array}$ & $\begin{array}{c}34.9 \\
(26.6-44.3)\end{array}$ & $\begin{array}{c}35.5 \\
(31.9-39.2)\end{array}$ & $\begin{array}{c}34.0 \\
(29.7-38.7)\end{array}$ & $\begin{array}{c}27.2 \\
(20.6-35.0)\end{array}$ & $\begin{array}{c}19.1 \\
(15.8-23.0)\end{array}$ & $\begin{array}{c}24.8 \\
(20.0-30.4)\end{array}$ & $\begin{array}{c}18.7 \\
(15.0-23.2)\end{array}$ & $\begin{array}{c}19.4 \\
(16.7-22.5)\end{array}$ \\
\hline \multicolumn{11}{|l|}{ School grade } \\
\hline 9 th & $\begin{array}{c}23.2 \\
(19.5-27.4)\end{array}$ & $\begin{array}{c}27.8 \\
(25.4-30.3)\end{array}$ & $\begin{array}{c}31.2 \\
(29.5-32.9)\end{array}$ & $\begin{array}{c}33.4 \\
(28.4-38.9)\end{array}$ & $\begin{array}{c}27.6 \\
(24.0-31.6)\end{array}$ & $\begin{array}{c}23.9 \\
(21.1-27.0)\end{array}$ & $\begin{array}{c}17.4 \\
(15.0-20.1)\end{array}$ & $\begin{array}{c}19.7 \\
(17.5-22.1)\end{array}$ & $\begin{array}{c}14.3 \\
(11.9-17.1)\end{array}$ & $\begin{array}{c}13.5 \\
(12.0-15.3)\end{array}$ \\
\hline 10 th $^{9}$ & $\begin{array}{c}25.2 \\
(22.5-28.1)\end{array}$ & $\begin{array}{c}28.0 \\
(24.7-31.6)\end{array}$ & $\begin{array}{c}33.1 \\
(29.3-37.1)\end{array}$ & $\begin{array}{c}35.3 \\
(31.2-39.7)\end{array}$ & $\begin{array}{c}34.7 \\
(32.2-37.2)\end{array}$ & $\begin{array}{c}26.9 \\
(23.8-30.3)\end{array}$ & $\begin{array}{c}21.8 \\
(19.0-24.9)\end{array}$ & $\begin{array}{c}21.4 \\
(18.4-24.8)\end{array}$ & $\begin{array}{c}19.6 \\
(16.7-22.8)\end{array}$ & $\begin{array}{c}18.3 \\
(15.9-21.0)\end{array}$ \\
\hline 11 th & $\begin{array}{c}31.6 \\
(27.8-35.7)\end{array}$ & $\begin{array}{c}31.1 \\
(27.9-34.4)\end{array}$ & $\begin{array}{c}35.9 \\
(32.0-39.9)\end{array}$ & $\begin{array}{c}36.6 \\
(32.9-40.4)\end{array}$ & $\begin{array}{c}36.0 \\
(33.1-39.1)\end{array}$ & $\begin{array}{c}29.8 \\
(26.1-33.7)\end{array}$ & $\begin{array}{c}23.6 \\
(20.5-27.0)\end{array}$ & $\begin{array}{c}24.3 \\
(21.2-27.7)\end{array}$ & $\begin{array}{c}21.6 \\
(18.4-25.2)\end{array}$ & $\begin{array}{c}22.3 \\
(19.6-25.2)\end{array}$ \\
\hline $12 \mathrm{th}^{\pi}$ & $\begin{array}{c}30.1 \\
(25.7-34.8)\end{array}$ & $\begin{array}{c}34.5 \\
(30.7-38.5)\end{array}$ & $\begin{array}{c}38.2 \\
(34.6-41.9)\end{array}$ & $\begin{array}{c}39.6 \\
(34.7-44.6)\end{array}$ & $\begin{array}{c}42.8 \\
(37.2-48.5)\end{array}$ & $\begin{array}{c}35.2 \\
(31.1-39.5)\end{array}$ & $\begin{array}{c}26.2 \\
(23.4-29.3)\end{array}$ & $\begin{array}{c}27.6 \\
(24.0-31.5)\end{array}$ & $\begin{array}{c}26.5 \\
(22.5-30.8)\end{array}$ & $\begin{array}{c}25.2 \\
(22.5-28.1)\end{array}$ \\
\hline
\end{tabular}

* Smoked cigarettes on at least 1 day during the 30 days before the survey.

† Linear, quadratic, and cubic trend analyses were conducted using a logistic regression model controlling for sex, race/ethnicity, and grade.

$\S$ Confidence intervals.

I Significant linear, quadratic, and cubic effects were detected $(p<0.05)$.

** Numbers for other racial/ethnic groups were too small for meaningful analysis.

${ }^{+\dagger}$ Significant linear and quadratic effects only were detected $(p<0.05)$.

\section{References}

1. CDC. Cigarette use among high school students-United States, 1991-2007. MMWR 2008;57:686-8.

2. Zaza S, Briss PA, Harris KW, eds. Tobacco. In: The guide to community preventive services: what works to promote health? New York, NY: Oxford University Press; 2005. Available at http://www.thecommunityguide.org/tobacco/ default.htm. Accessed July 1, 2010.

3. CDC. Best practices for comprehensive tobacco control programs - 2007. Atlanta, GA: US Department of Health and Human Services, CDC; 2007. Available at http://www.cdc. gov/tobacco/tobacco_control_programs/stateandcommunity/ best_practices. Accessed July 1, 2010.

4. Institute of Medicine. Ending the tobacco problem: a blueprint for the nation. Washington DC: National Academies Press; 2007.

5. CDC. CDC grand rounds: current opportunities in tobacco control. MMWR 2010;59:487-92.

6. Johnston LD, O’Malley PM, Bachman JG, Schulenberg JE. Trends in prevalence of use of cigarettes in grades 8,10 , and 12. Table 1. Ann Arbor, MI: University of Michigan; 2009. Available at http://monitoringthefuture.org/data/09data. html\#2009data-cigs. Accessed July 1, 2010.
7. Nelson DE, Mowery P, Asman K, et al. Long-term trends in adolescent and young adult smoking in the United States: metapatterns and implications. Am J Public Health 2008;98: 905-17.

8. National Cancer Institute. The role of the media in promoting and reducing tobacco use. Tobacco control monograph no. 19. Bethesda, MD: US Department of Health and Human Services, National Institutes of Health, National Cancer Institute; 2008. Available at http://cancercontrol.cancer.gov/ tcrb/monographs/19/m19_complete.pdf. Accessed July 1, 2010.

9. Catalid EF, Laird J, KewalRamani A. High school dropout and completion rates in the United States: 2007. Washington, DC: US Department of Education, National Center for Education Statistics, 2007. Available at http://nces.ed.gov/ pubs2009/2009064.pdf. Accessed July 1, 2010.

10. Brener ND, Kann L, McManus T, Kinchen SA, Sundberg EC, Ross JG. Reliability of the 1999 Youth Risk Behavior Survey questionnaire. J Adolesc Health 2002;31:336-42. 


\section{Progress Toward Poliomyelitis Eradication - Nigeria, January 2009-June 2010}

Nigeria has maintained a high incidence of wild poliovirus (WPV) cases attributed to persistently high proportions of under- and unimmunized children, and, for many years, the country has served as a reservoir for substantial international spread (1). In 2008, Nigeria reported 798 polio cases, the highest number of any country in the world (2). This report provides an update on poliovirus epidemiology in Nigeria during the past 18 months, January 2009-June 2010, and describes activities planned to interrupt transmission. Reported WPV cases in Nigeria decreased to 388 during 2009 (24\% of global cases), and WPV incidence in Nigeria reached an all-time low during January-June 2010, with only three reported cases. Cases of circulating type 2 vaccine-derived poliovirus (cVDPV2), which first occurred in Nigeria in 2005 (3), also declined, from 148 during the 12 months of 2009 , to eight during the 6 -month period, January-June 2010. One indicator of the effectiveness of immunization activities is the proportion of children with nonpolio acute flaccid paralysis (AFP) who never have received oral poliovirus vaccine (OPV). In seven high-incidence northern states of Nigeria, this proportion declined from $17.6 \%$ in 2008 to $10.7 \%$ in 2009. During 2009-2010, increased engagement of traditional, religious, and political leaders has improved community acceptance of vaccination and implementation of high-quality supplementary immunization activities (SIAs). Enhanced surveillance for polioviruses, further strengthened implementation of SIAs, and immediate immunization responses to newly identified WPV and cVDPV2 cases will be pivotal in interrupting WPV and cVDPV2 transmission in Nigeria.

\section{Immunization Activities}

Routine immunization against polio in Nigeria consists of trivalent OPV (tOPV, types 1, 2, and 3) at birth and at ages 6,10 , and 14 weeks. Immunization coverage is measured using both administrative data (estimated doses administered per targeted child population, determined by official census numbers) and coverage surveys. In 2009, using administrative data, national routine immunization coverage of children by age 12 months with three tOPV doses was
63\% (range by state: 35\%-90\%) (4). Using coverage surveys, the estimated national coverage with three tOPV doses at 12-23 months was 39\%, but lower in the northeast $(28.6 \%)$ and northwest (24.3\%) areas of Nigeria, including the seven high-incidence northern states (5).*

In addition to routine immunization, Nigeria conducts SIAs ${ }^{\dagger}$ for polio eradication using monovalent OPV type 1 (mOPV1), monovalent OPV type 3 (mOPV3), bivalent OPV types 1 and 3 (bOPV), or tOPV. Monovalent vaccines are more effective than tOPV in providing protection against the corresponding WPV serotype; bOPV is nearly equivalent to mOPV and superior to tOPV in producing seroconversion to WPV1 and WPV3 (G). Three national SIAs were conducted in 2009, using mOPV3, mOPV1, and tOPV. Five subnational SIAs were conducted in 2009, each using mOPV1, mOPV3, tOPV, or both mOPV1 and mOPV3. During January-June 2010, two national SIAs were conducted, one with bOPV and one with tOPV; bOPV, mOPV1, and mOPV3 were used in three subnational SIAs (Figure 1).

Vaccination histories of children with nonpolio AFP are used to estimate OPV coverage among the population of children aged 6-59 months. The proportion of children with nonpolio AFP reported to have never received an OPV dose (zero-dose children) from the seven high-incidence northern states declined from $17.6 \%$ in 2008 to $10.7 \%$ in 2009 (range: $0 \%-17.0 \%$ ), with the highest proportions occurring in Zamfara and Kano states (Table). In contrast, the proportion of reported zero-dose children was $2.2 \%$ in 13 other northern states and $1.8 \%$ in 17 southern states in 2009 . The proportion of children with nonpolio AFP reported to have received $\geq 4 \mathrm{OPV}$ doses was $37.4 \%$ in the seven high-incidence northern states and $60.8 \%$ for the entire country.

\footnotetext{
${ }^{*}$ For this report, high-incidence northern states are defined as states with $\geq 0.8$ confirmed WPV cases per 100,000 population during 2008. They are Bauchi, Jigawa, Kaduna, Kano, Katsina, Yobe, and Zamfara.

${ }^{\dagger}$ Mass campaigns conducted during a short period (days to weeks) during which a dose of OPV is administered to all children aged $<5$ years, regardless of previous vaccination history. Campaigns can be conducted nationally or in portions of the country (i.e., subnational SIAs).
} 
FIGURE 1. Number of laboratory-confirmed cases, by wild poliovirus (WPV) type or circulating vaccine-derived poliovirus type 2 (cVDPV2) and month of onset, type of supplementary immunization activity (SIA),* and type of vaccine administered — Nigeria, January 2007-June 2010

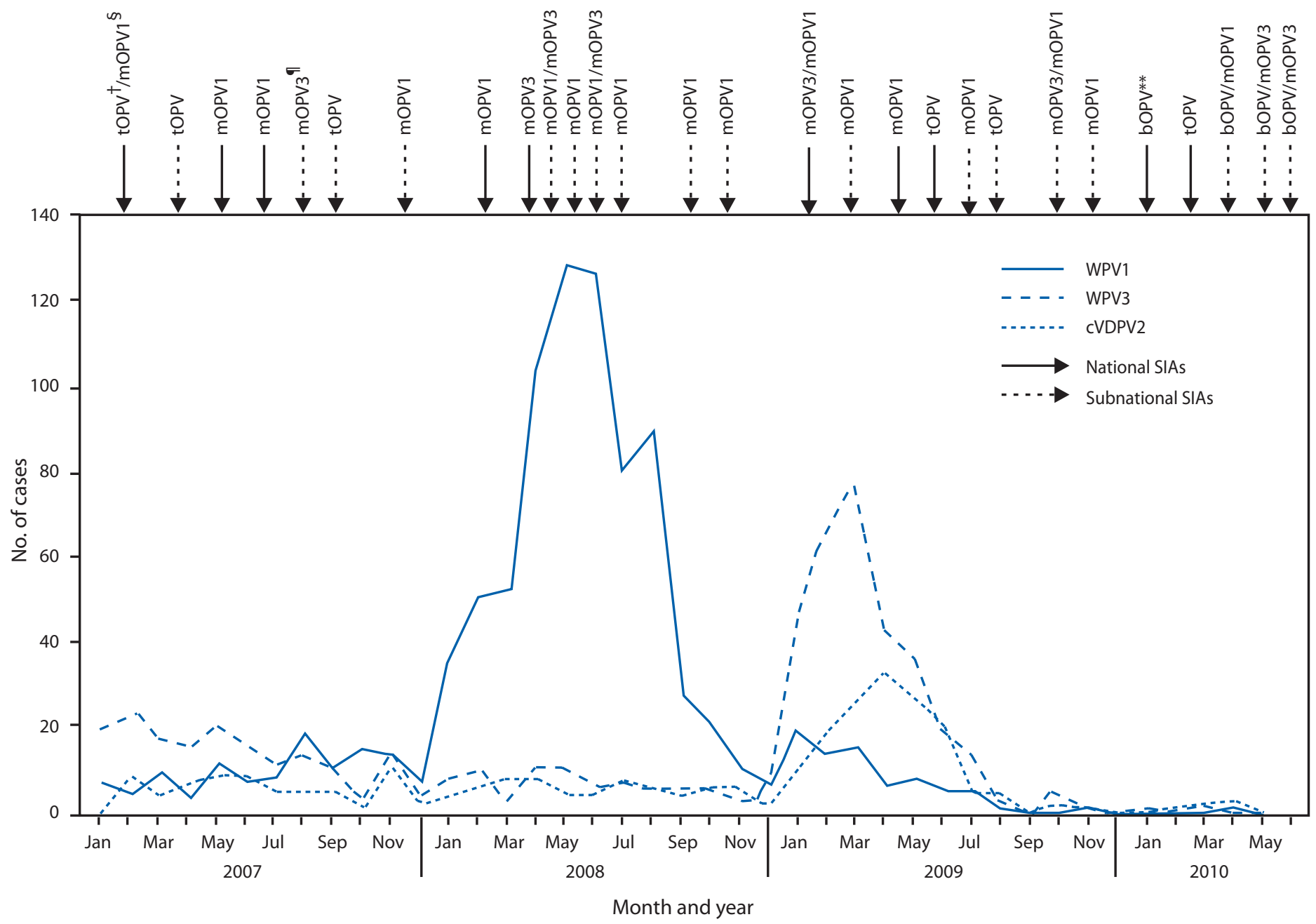

* Mass campaign conducted during a short period (days to weeks) during which a dose of oral poliovirus vaccine (OPV) is administered to all children aged $<5$ years, regardless of previous vaccination history. Campaigns can be conducted nationally or in portions of the country.

† Trivalent OPV.

$\S$ Monovalent OPV type 1.

"Monovalent OPV type 3.

** Bivalent OPV.

\section{AFP Surveillance}

AFP surveillance is monitored using World Health Organization (WHO) targets for case detection and adequate stool specimen collection. ${ }^{\$}$ The national

\footnotetext{
$\overline{\S \text { AFP cases in children aged }}<15$ years and suspected poliomyelitis in persons of any age are reported and investigated, with laboratory testing, as possible polio. WHO operational targets for countries at high risk for poliovirus transmission are a nonpolio AFP rate of at least two cases per 100,000 population aged $<15$ years at each subnational level and adequate stool specimen collection for $>80 \%$ of AFP cases (i.e., two specimens collected at least 24 hours apart, both within 14 days of paralysis onset, and shipped on ice or frozen ice packs to a WHO-accredited laboratory and arriving at the laboratory in good condition).
}

annualized nonpolio AFP detection rate among children aged $<15$ years was 8.2 per 100,000 during January-March 2009 and 9.0 per 100,000 during January-March 2010. Nonpolio AFP detection rates meeting the WHO target were achieved in all 37 Nigerian states during January-December 2009 and in all but one state (Plateau) during January-March 2010.

The WHO adequate stool specimen target was reached in all 37 states and in $683(88 \%)$ of 776 local government areas (LGAs) during January-December 2009, and in 36 states and 557 (72\%) LGAs during 
TABLE. Number and percentage of nonpolio acute flaccid paralysis (AFP) reported cases among children aged 6-59 months with zero doses,* 1-3 doses, and $\geq 4$ doses of oral polio vaccine (OPV) - Nigeria, 2008-2009

\begin{tabular}{|c|c|c|c|c|c|c|c|c|c|c|c|c|c|c|}
\hline \multirow[b]{3}{*}{ Region/State } & \multicolumn{7}{|c|}{2008} & \multicolumn{7}{|c|}{2009} \\
\hline & \multirow{2}{*}{$\begin{array}{c}\text { No. of } \\
\text { nonpolio } \\
\text { AFP } \\
\text { cases }\end{array}$} & \multicolumn{2}{|c|}{ Zero doses } & \multicolumn{2}{|c|}{$1-3$ doses } & \multicolumn{2}{|c|}{$\geq 4$ doses } & \multirow{2}{*}{$\begin{array}{c}\text { No. of } \\
\text { nonpolio } \\
\text { AFP } \\
\text { cases }\end{array}$} & \multicolumn{2}{|c|}{ Zero doses } & \multicolumn{2}{|c|}{$1-3$ doses } & \multicolumn{2}{|c|}{$\geq 4$ doses } \\
\hline & & No. & (\%) & No. & (\%) & No. & (\%) & & No. & (\%) & No. & (\%) & No. & (\%) \\
\hline High-incidence northern states ${ }^{\dagger}$ & 1,172 & 206 & $(17.6)$ & 638 & $(54.4)$ & 302 & $(25.8)$ & 1,068 & 114 & $(10.7)$ & 542 & $(50.7)$ & 399 & $(37.4)$ \\
\hline Bauchi & 96 & 13 & $(13.5)$ & 46 & $(47.9)$ & 36 & $(37.5)$ & 78 & 0 & $(0.0)$ & 23 & $(29.5)$ & 55 & $(70.5)$ \\
\hline Jigawa & 99 & 5 & $(5.1)$ & 69 & $(69.7)$ & 25 & $(25.3)$ & 90 & 4 & (4.4) & 40 & $(44.4)$ & 46 & $(51.1)$ \\
\hline Kaduna & 140 & 26 & $(18.6)$ & 50 & $(35.7)$ & 64 & $(45.7)$ & 121 & 6 & $(5.0)$ & 45 & $(37.2)$ & 70 & $(57.9)$ \\
\hline Kano & 382 & 104 & $(27.2)$ & 184 & $(48.2)$ & 73 & $(19.1)$ & 358 & 61 & $(17.0)$ & 192 & $(53.6)$ & 95 & $(26.5)$ \\
\hline Katsina & 197 & 32 & $(16.2)$ & 111 & $(56.3)$ & 52 & $(26.4)$ & 153 & 14 & $(9.2)$ & 80 & $(52.3)$ & 57 & (37.3) \\
\hline Yobe & 98 & 2 & $(2.0)$ & 67 & $(68.4)$ & 27 & $(27.6)$ & 139 & 10 & $(7.2)$ & 77 & $(55.4)$ & 51 & $(36.7)$ \\
\hline Zamfara & 160 & 24 & $(15.0)$ & 111 & $(69.4)$ & 25 & $(15.6)$ & 129 & 19 & $(14.7)$ & 85 & $(65.9)$ & 25 & $(19.4)$ \\
\hline Other northern states $\S$ & 1,233 & 58 & $(4.7)$ & 386 & (31.3) & 778 & $(63.1)$ & 1,378 & 30 & $(2.2)$ & 380 & $(27.6)$ & 965 & $(70.3)$ \\
\hline Southern states & 1,301 & 26 & $(2.0)$ & 391 & $(30.1)$ & 874 & $(67.2)$ & 1,369 & 25 & (1.8) & 375 & $(27.4)$ & 955 & $(69.8)$ \\
\hline Total & 3,706 & 290 & (7.8) & 1,415 & (38.2) & 1,954 & (52.7) & 3,815 & 169 & (4.4) & 1,297 & $(34.0)$ & 2,319 & $(60.8)$ \\
\hline
\end{tabular}

* Children who have never received an OPV dose, as reported by caregiver.

${ }^{\dagger}$ High-incidence states had $\geq 0.8$ confirmed wild poliovirus cases per 100,000 population during 2008.

$\S$ Adamawa, Benue, Borno, Federal Capital Territory, Gombe, Kebbi, Kegi, Kwara, Nasarawa, Niger, Plateau, Sokoto, and Taraba.

" Abia, Akwa Ibom, Anambra, Bayelsa, Cross River, Delta, Ebonyi, Edo, Ekiti, Enugu, Imo, Lagos, Ogun, Ondo, Osun, Oyo, and Rivers.

January-March 2010. The proportion of LGAs meeting both surveillance indicators (nonpolio AFP detection rate meeting the target and adequate stool specimen collection rate) rose from $78 \%$ in 2008 to $86 \%$ in 2009.

\section{WPV and cVDPV Incidence}

Reported WPV type 1 (WPV1) cases declined from 67 during January-June 2009 to seven during JulyDecember 2009, and to one case during January-June 2010 (provisional data, as of July 5, 2010) (Figure 2). Of the 75 WPV1 cases reported during the entire 18-month period, January 2009-June 2010, seven (9\%) occurred in the seven high-incidence northern states, $33(44 \%)$ in other northern states, and 35 $(47 \%)$ in southern states. The number of LGAs with WPV1 cases declined from 49 during January-June 2009 to one during January-June 2010 (Figure 2). Reported WPV type 3 (WPV3) cases declined from 290 during January-June 2009 to 24 during JulyDecember 2009, and to two during January-June 2010. Only three cases of WPV have been reported during the first 6 months of 2010. Among 316 WPV3 cases reported from January 2009-June 2010, $240(76 \%)$ occurred in the high-incidence northern states, $75(24 \%)$ in other northern states, and one $(<1 \%)$ in southern states. The number of LGAs with WPV3 cases declined from 147 in January-June 2009 to two during January-June, 2010 (Figure 2). Of 391 WPV cases reported with onset during January 2009-June 2010, 270 (69\%) occurred in children aged $<3$ years, $266(68 \%)$ were in children reported to have received $<4$ OPV doses, and $66(17 \%)$ were in zero-dose children. The number of cVDPV2 cases declined from 137 during January-June 2009 to 11 during July-December 2009, and to eight during January-June 2010.

All WPV isolates undergo partial genomic sequencing to determine genetic relatedness. Each 1\% difference between two isolates correlates with approximately 1 year of undetected circulation between the specific chains of transmission. Differences greater than $1.5 \%$ indicate potential quality issues for surveillance. Three of the seven WPV1 isolates from July-December 2009 cases and the one WPV1 isolate from 2010 exhibited $>1.5 \%$ divergence from the closest predecessor. Similarly, nine of the 24 (38\%) WPV3 isolates from July-December 2009 and both 2010 WPV3 exhibited $\geq 1.5 \%$ divergence.

\section{Reported by}

National Primary Health Care Development Agency and Federal Ministry of Health; Country Office of the World Health Organization, Abuja; Poliovirus Laboratory, Univ of Ibadan, Ibadan; Poliovirus Laboratory, Univ of Maiduguri Teaching Hospital, Maiduguri, Nigeria. African Regional Polio Reference Laboratory, National Institute for Communicable Diseases, Johannesburg, South Africa. Vaccine Preventable Diseases, World Health Organization Regional Office for Africa, Brazzaville, Congo. Polio Eradication Dept, World Health Organization, Geneva, Switzerland. Div of Viral Dis- 
FIGURE 2. Local government areas (LGAs) with laboratory-confirmed cases of wild poliovirus type 1 (WPV1) and type 3 (WPV3) - Nigeria, January-June 2009 and January-June 2010*

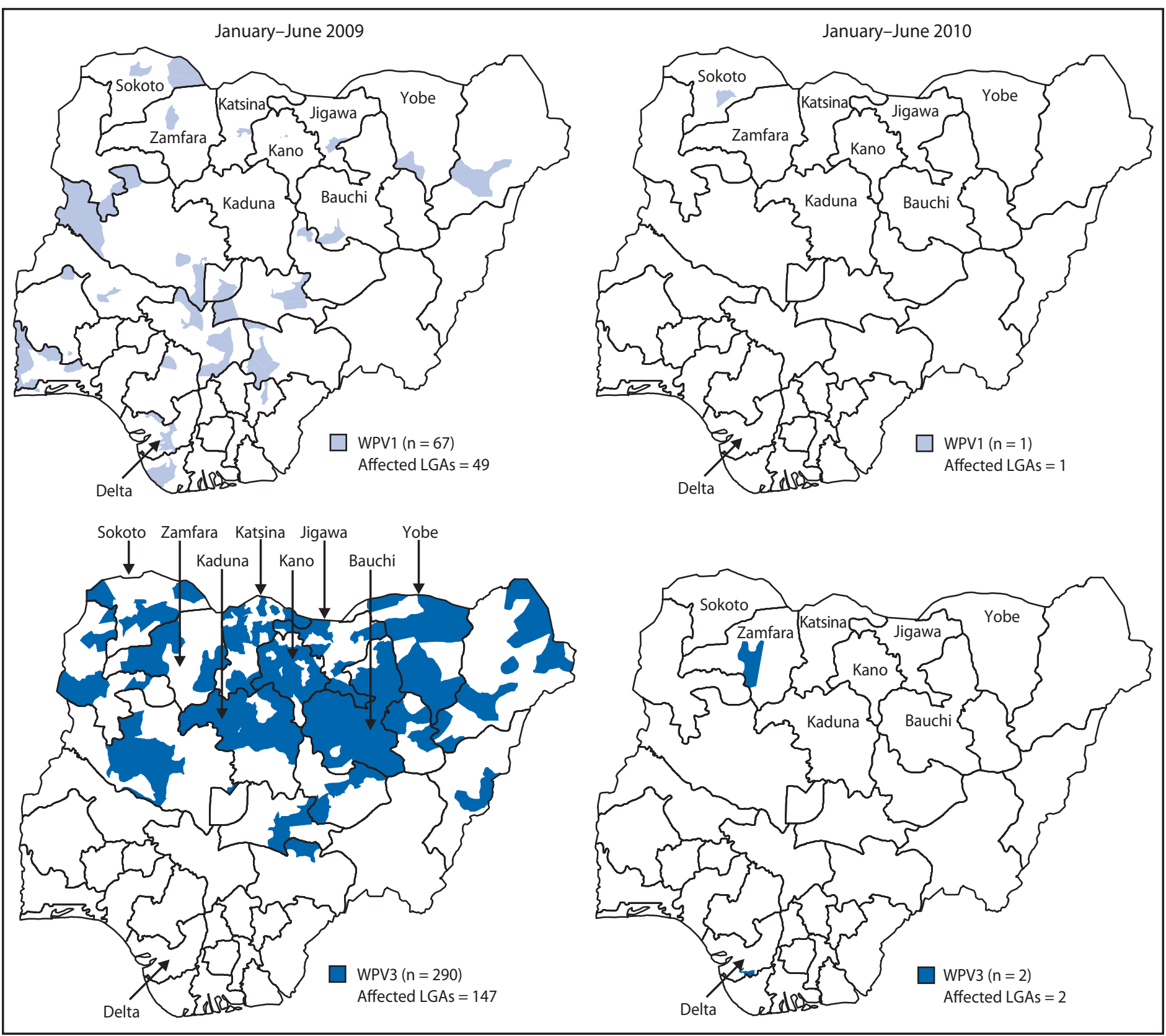

* During 2008, Bauchi, Jigawa, Kaduna, Kano, Katsina, Yobe, and Zamfara had $\geq 0.8$ confirmed WPV cases per 100,000 population and were defined as high-incidence northern states. During January-June 2010, confirmed WPV1 in Nigeria occurred only in Sokoto, and WPV3 occurred only in Delta and Zamfara. 
What is already known on this topic?

In 2008, 798 cases of wild poliovirus (WPV) (48\% of global cases) were reported in Nigeria, one of four remaining countries (including India, Pakistan, and Afghanistan) that have never eliminated WPV transmission of both serotypes 1 and 3 .

What is added by this report?

From 2008 to 2009, cases of WPV in Nigeria declined substantially (from 798 cases to 388), now accounting for $<1 \%$ of reported global WPV cases, and during the first 6 months of 2010, only three WPV cases were reported. Among children with nonpolio acute flaccid paralysis, the decline from $17.6 \%$ in 2008 to $10.7 \%$ in 2009 of zero-dose children in high-incidence northern states indicates that population immunity might be steadily increasing in areas that traditionally have been responsible for extensive WPV transmission.

What are the implications for public health practice?

With sustained support of traditional, religious, and political leaders to improve implementation of polio vaccination activities and to improve surveillance for polio cases, Nigeria has the potential to eliminate WPV transmission in the near future.

eases and Global Immunization Div, National Center for Immunization and Respiratory Diseases, CDC.

\section{Editorial Note}

Since 2003, Nigeria has served as the major reservoir for WPV1 and WPV3 circulation in West Africa and Central Africa ( 7 ). Over the past 8 years, WPV of Nigerian origin has been imported into 26 countries in Africa, the Middle East, and Asia, and has led to reestablished transmission ( $>12$ months) in Chad and Sudan.

Factors related to high WPV incidence in Nigeria during the last decade have included loss of public confidence in OPV during 2003-2004 (8), longstanding insufficiencies in health infrastructure resulting in low routine vaccination coverage, and poorly implemented SIAs that have failed to reach $>80 \%$ of children in high-risk states. With substantial reductions in WPV1, WPV3, and cVDPV2 cases during January-June 2010 compared with the same period in 2009, Nigeria has shown substantial progress, suggesting improvements in vaccine coverage with highquality SIAs. The increased engagement of traditional, religious, and political leadership at the federal, state, and local levels has been instrumental in improving vaccine acceptance and SIA implementation. If this progress can be sustained throughout the upcoming season (July-September), during which WPV transmission is traditionally high, WPV transmission in Nigeria could be disrupted in the near future. Progress elsewhere, including successful implementation of synchronized SIAs in West Africa and Central Africa to stem regional WPV circulation, would remove a potential threat of reimportation into Nigeria and ultimately lead to a polio-free Africa. However, multiple challenges must be overcome to sustain the gains in Nigeria.

Within the seven high-incidence northern states, a high proportion of children remain at risk as a result of low routine immunization coverage and high birth rates. This report indicates that, during 2008-2009, a substantial drop occurred in the proportion of children with nonpolio AFP who had received no doses of vaccine (i.e., from $17.6 \%$ in 2008 to $10.7 \%$ in 2009 ) in the seven high-incidence states. However, even with this decrease, in 2009, a majority of such children (50.7\%) remained undervaccinated with $1-3$ doses of OPV. Until the proportion of children vaccinated with $\geq 4$ doses is $>80 \%$ and the proportion of zerodose children is $<10 \%$ in each state, the risk remains that WPV transmission will continue (9).

The quality of SIA implementation remains variable and highly dependent on LGA commitment and resources, including timely disbursement of funds in support of SIAs. Successful implementation of SIAs planned for the remainder of 2010 will require ongoing engagement of LGA leadership and supervision, with close monitoring of performance indicators at the LGA, state, and federal levels. Since emerging in 2005-2006, cVDPV2 continues to circulate in northern Nigeria. Continued use of high-quality SIAs with tOPV will be needed to further control and eliminate cVDPV2 transmission, while routine immunization services are strengthened. Any new WPV case should trigger rapid, type-specific vaccination responses ("mop-up" SIAs).

Genomic sequence analysis indicates that some chains of WPV transmission during 2009-2010 have not been detected for more than a year, suggesting limitations in surveillance quality despite AFP surveillance performance indicators meeting or 
exceeding targets at national and virtually all state levels. Surveillance gaps might be occurring among specific subpopulations such as migrants in northern Nigeria, including Fulani nomads, who have limited access to immunization activities and health-care providers. Further efforts to enhance and supplement AFP surveillance to detect WPV and cVDPV should include seeking reports from nontraditional healers, testing waste water for polioviruses, and identifying and improving surveillance in LGAs not meeting performance criteria.

\section{References}

1. CDC. Wild poliovirus type 1 and type 3 importations -15 countries, Africa, 2008-2009. MMWR 2009;58:357-62.

2. CDC. Progress toward poliomyelitis eradication-Nigeria, 2008-2009. MMWR 2009;58:1150-4.

3. CDC. Update on vaccine-derived polioviruses-worldwide, January 2008-June 2009. MMWR 2009;58:1002-6.
4. World Health Organization. Immunization surveillance, assessment, and monitoring. country immunization profileNigeria. Geneva, Switzerland: World Health Organization; 2010. Available at http://apps.who.int/immunization_ monitoring/en/globalsummary/countryprofileselect.cfm. Accessed June 11, 2010.

5. ICF Macro. Nigeria, 2008 demographic health survey, key findings. Calverton, MD: ICF Macro; 2008. Available at http:// www.measuredhs.com/pubs/pdf/sr173/sr173.pdf. Accessed February 26, 2010.

6. World Health Organization. Advisory Committee on Poliomyelitis Eradication: recommendations on the use of bivalent oral poliovirus vaccine types 1 and 3. Wkly Epidemiol Rec 2009;84:289-90.

7. CDC. Progress toward interruption of wild poliovirus transmission-worldwide, 2009. MMWR 2010;59:545-50.

8. Jegede AS. What led to the Nigerian boycott of the polio vaccination campaign? PLoS Med 2007;4(3):e73.

9. Jenkins HE, Aylward RB, Gasasira A, et al. Effectiveness of immunization against paralytic poliomyelitis in Nigeria. $\mathrm{N}$ Engl J Med 2008;359:1666-74. 


\section{Vital Signs: Colorectal Cancer Screening Among Adults Aged 50-75 Years — United States, 2008}

On July 6, this report was posted as an MMWR Early Release on the MMWR website (http://www.cdc.gov/mmwr).

\section{ABSTRACT}

Background: Colorectal cancer (CRC) remains the second leading cause of cancer deaths in the United States and the leading cause of cancer deaths among nonsmokers. Statistical modeling indicates that, if current trends in health behaviors, screening, and treatment continue, U.S. residents can expect to see a $36 \%$ decrease in the CRC mortality rate by 2020 , compared with 2000.

Methods: Every 2 years, CDC uses Behavioral Risk Factor Surveillance System data to estimate up-to-date CRC screening prevalence in the United States. Adults aged $\geq 50$ years were considered to be up-to-date with CRC screening if they reported having a fecal occult blood test (FOBT) within the past year or lower endoscopy (i.e., sigmoidoscopy or colonoscopy) within the preceding 10 years. Prevalence was calculated for adults aged 50-75 years based on current U.S. Preventive Services Task Force recommendations.

Results: For 2008, the overall age-adjusted CRC screening prevalence for the United States was $62.9 \%$ among adult respondents aged $50-75$ years, increased from $51.9 \%$ in 2002 . Among the lowest screening prevalences were those reported by persons aged 50-59 years $(53.9 \%)$, Hispanics $(49.8 \%)$, persons with lower income $(47.6 \%)$, those with less than a high school education $(46.1 \%)$, and those without health insurance (35.6\%).

Conclusions: CRC screening rates continue to increase in the United States. Underscreening persists for certain racial/ethnic groups, lower socioeconomic groups, and the uninsured.

Implications for Public Health Practice: Health reform is anticipated to reduce financial barriers to CRC screening, but many factors influence CRC screening. The public health and medical communities should use methods, including client and provider reminders, to ensure test completion and receipt of follow-up care. Public health surveillance should be expanded and communication efforts enhanced to help the public understand the benefits of CRC screening.

Despite recent declines in both incidence and mortality, colorectal cancer (CRC) remains the second most common cause of cancer deaths after lung cancer in the United States (1) and the leading cause of cancer deaths among nonsmokers. In 2006 (the most recent data available), 139,127 people were diagnosed with colorectal cancer, and 53,196 people died (1). Screening for colorectal cancer is effective in reducing incidence and mortality by removal of premalignant polyps and through early detection and treatment of

CDC Vital Signs is a new series of MMWR reports that will announce the latest results for key public health indicators. cancer (2). CRC screening prevalence has improved over the past decade (3); however, in 2006, approximately $30 \%$ of eligible U.S. residents had never been screened for CRC (3). This Vital Signs report updates screening prevalence in the United States using data from the 2008 Behavioral Risk Factor Surveillance System (BRFSS) survey for persons aged $50-75$ years, based on recommendations for up-to-date CRC screening from the U.S. Preventive Services Task Force (USPSTF) (4).

\section{Methods}

BRFSS is a state-based, random-digit dialed telephone survey of the civilian, noninstitutionalized adult population that collects information on 
health risk behaviors, preventive health practices, and health-care access in the United States (5). Every 2 years (in even numbered years), respondents aged $\geq 50$ years are asked whether they have ever used a "special kit at home to determine whether the stool contains blood (fecal occult blood test [FOBT])," whether they have ever had a "tube inserted into the rectum to view the colon for signs of cancer or other health problems (sigmoidoscopy or colonoscopy)," and when these tests were last performed. CDC calculated the prevalence of adults who reported having had an FOBT within the past year or lower endoscopy (i.e., sigmoidoscopy or colonoscopy) within the preceding 10 years, as was done in previous reports (3). Based on the U.S. Preventive Services Task Force recommended screening age, this analysis was restricted to persons aged $50-75$ years (4). Data were aggregated across all 50 states and the District of Columbia. Respondents who refused to answer, had a missing answer, or who answered "don't know/not sure" were excluded from analysis of the question.

The median Council of American Survey and Research Organizations (CASRO) response rate was $53.3 \%$, and the median CASRO cooperation rate was $75.0 \%$ (5). Data were weighted to the age, sex, and racial/ethnic distribution of each state's adult population using intercensal estimates and were agestandardized to the 2008 BRFSS population.

\section{Results}

The 2008 BRFSS survey was administered to 414,509 respondents, of whom 201,157 were aged 50-75 years. The overall, age-adjusted combined upto-date CRC screening (FOBT and lower endoscopy) prevalence for the United States was 62.9\% among adult respondents aged 50-75 years (Table). Among the lowest screening prevalences were those reported by persons aged $50-59$ years $(53.9 \%)$, Hispanics (49.8\%), persons with lower income $(47.6 \%)$, those with less than a high school education (46.1\%), and those without health insurance (35.6\%). Similar patterns were noted for FOBT in the preceding year and for lower endoscopy in the preceding 10 years. The percentage of persons up-to-date with CRC screening ranged from $53.2 \%$ in Oklahoma to $74.1 \%$ in Massachusetts (Figure 1). States with the highest screening prevalence were concentrated in the northeastern United States. CRC screening increased from $51.9 \%$ in 2002 to $62.9 \%$ in 2008 (Figure 2). During that period, use of endoscopy increased, while FOBT

\section{Key Points for the Public}

- Over 53,000 U.S. residents die each year from colorectal cancer.

- 1,900 deaths could be prevented each year for every $10 \%$ increase in colonoscopy screening.

- Only $36 \%$ of men and women without health insurance are up-to-date with colorectal cancer screening.

- Additional information is available at http://www.cdc.gov/vitalsigns.

use declined from $20.9 \%$ of CRC screening in 2002 to $14.1 \%$ in 2008 .

\section{Conclusions and Comment}

The results in this Vital Signs report indicate that the prevalence of up-to-date CRC screening in the United States is continuing to increase. An increase (from $38 \%$ in 2000 to $53 \%$ in 2008) also has been reported using National Health Interview Survey data (6). However, in 2008, certain populations in the United States remained underscreened, including those with lower socioeconomic status, Hispanics, and those without health insurance. Multiple factors might explain these differences, including patient education and income, as well as provider and clinical systems factors. As in previous surveys, the 2008 survey indicated notable geographic differences in CRC screening prevalence. The reasons for these geographic differences remain unknown, but screening capacity, lack of physician availability, and patient factors including income, education, and lack of awareness have been proposed as reasons ( 6 ).

CRC screening rates continue to increase in the United States. Additional improvements in screening prevalence might have substantive impact on CRC mortality. Statistical modeling indicates that, if current trends in health behaviors, screening, and treatment continue, U.S. residents can expect to see a 36\% decrease in the CRC mortality rate by 2020 , compared with 2000 (7).

Insufficient evidence exists to recommend "one best" test for CRC screening. Several proven, effective tests exist and are recommended by USPSTF, including annual FOBT, sigmoidoscopy every 5 years, 
TABLE. Percentage of respondents aged 50-75 years who reported receiving a fecal occult blood test (FOBT) within 1 year, or a lower endoscopy* within 10 years, by selected characteristices - Behavioral Risk Factor Surveillance System (BRFSS), United States, $2008^{\dagger}$

\begin{tabular}{|c|c|c|c|c|c|c|}
\hline \multirow[b]{2}{*}{ Characteristic } & \multicolumn{2}{|c|}{ FOBT within $1 \mathrm{yr}$} & \multicolumn{2}{|c|}{$\begin{array}{l}\text { Lower endoscopy } \\
\text { within } 10 \text { yrs }\end{array}$} & \multicolumn{2}{|c|}{$\begin{array}{l}\text { FOBT within } 1 \text { yr or lower } \\
\text { endoscopy within } 10 \mathrm{yrs}\end{array}$} \\
\hline & $\%$ & $\left(95 \% \mathrm{Cl}^{\S}\right)$ & $\%$ & $(95 \% \mathrm{Cl})$ & $\%$ & $(95 \% \mathrm{Cl})$ \\
\hline Overall & 14.1 & $(13.8-14.4)$ & 58.5 & $(58.1-59.0)$ & 62.9 & $(62.5-63.3)$ \\
\hline \multicolumn{7}{|l|}{ Age group (yrs) } \\
\hline $50-59$ & 11.0 & $(10.6-11.4)$ & 49.7 & $(49.0-50.3)$ & 53.9 & $(53.3-54.5)$ \\
\hline $60-69$ & 17.0 & $(16.5-17.6)$ & 66.7 & $(66.0-67.3)$ & 71.1 & $(70.5-71.7)$ \\
\hline $70-75$ & 18.2 & $(17.4-19.1)$ & 71.4 & $(70.4-72.3)$ & 75.8 & $(74.8-76.7)$ \\
\hline \multicolumn{7}{|l|}{ Sex } \\
\hline Men & 14.6 & $(14.2-15.1)$ & 59.0 & $(58.4-59.7)$ & 63.2 & $(62.6-63.9)$ \\
\hline Women & 13.6 & $(13.2-13.9)$ & 58.1 & $(57.6-58.6)$ & 62.6 & $(62.0-63.1)$ \\
\hline \multicolumn{7}{|l|}{ Race } \\
\hline White & 13.8 & $(13.5-14.1)$ & 59.8 & $(59.4-60.2)$ & 63.9 & $(63.5-64.4)$ \\
\hline Black & 17.2 & $(16.0-18.6)$ & 56.6 & $(55.0-58.2)$ & 62.0 & $(60.5-63.6)$ \\
\hline Asian/Pacific Islander & 13.5 & $(11.0-16.6)$ & 51.1 & $(47.2-55.0)$ & 55.5 & $(51.6-59.4)$ \\
\hline American Indian/Alaska Native & 15.1 & $(12.3-18.3)$ & 50.7 & $(46.7-54.6)$ & 54.4 & $(50.4-58.4)$ \\
\hline Other & 11.8 & $(9.7-14.1)$ & 43.7 & $(40.6-46.9)$ & 49.3 & $(46.1-52.6)$ \\
\hline \multicolumn{7}{|l|}{ Ethnicity } \\
\hline Hispanic & 12.0 & $(10.5-13.7)$ & 45.8 & $(43.6-48.0)$ & 49.8 & $(47.6-52.0)$ \\
\hline Non-Hispanic & 14.3 & $(14.0-14.6)$ & 59.8 & $(59.4-60.2)$ & 64.2 & $(63.8-64.6)$ \\
\hline \multicolumn{7}{|l|}{ Education level } \\
\hline$<$ High school & 11.3 & $(10.4-12.3)$ & 41.8 & $(40.1-43.5)$ & 46.1 & $(44.4-47.8)$ \\
\hline High school graduate/GED? & 13.3 & $(12.8-13.8)$ & 53.3 & $(52.5-54.0)$ & 58.1 & $(57.3-58.8)$ \\
\hline Some college/tech school & 15.0 & $(14.4-15.6)$ & 59.2 & $(58.4-60.0)$ & 63.7 & $(63.0-64.5)$ \\
\hline College graduate & 14.9 & $(14.3-15.4)$ & 66.9 & $(66.3-67.6)$ & 70.6 & $(70.0-71.3)$ \\
\hline \multicolumn{7}{|l|}{ Annual household income (\$) } \\
\hline$<15,000$ & 11.8 & $(10.8-12.8)$ & 42.3 & $(40.7-43.9)$ & 47.6 & $(46.0-49.3)$ \\
\hline $15,000-34,999$ & 13.9 & $(13.2-14.6)$ & 48.9 & $(48.0-49.8)$ & 54.0 & $(53.0-54.9)$ \\
\hline $35,000-49,999$ & 13.7 & $(13.0-14.4)$ & 57.1 & $(56.0-58.1)$ & 61.3 & $(60.2-62.3)$ \\
\hline $50,000-74,999$ & 14.1 & (13.4-14.9) & 62.7 & (61.7-63.7) & 66.5 & $(65.5-67.4)$ \\
\hline$\geq 75,000$ & 15.0 & $(14.4-15.6)$ & 69.4 & $(68.6-70.1)$ & 72.9 & $(72.2-73.6)$ \\
\hline \multicolumn{7}{|l|}{ Health insurance } \\
\hline Yes & 14.6 & $(14.3-14.9)$ & 61.3 & $(60.9-61.8)$ & 65.7 & $(65.3-66.1)$ \\
\hline No & 8.9 & $(7.9-10.1)$ & 31.3 & $(29.2-33.5)$ & 35.6 & $(33.4-37.9)$ \\
\hline
\end{tabular}

* Sigmoidoscopy or colonoscopy.

† Percentages standardized to the age distribution in the 2008 BRFSS survey.

$\S$ Confidence interval.

ๆ General Educational Development certificate.

and colonoscopy every 10 years (4). In addition to maximizing prevalence of CRC screening to reduce morbidity and mortality, ensuring proper follow-up of abnormal results is important to maximize the benefits of screening (4).

The findings in this report are subject to at least three limitations. First, because BRFSS is a telephone survey of residential households, only adults in households with landline telephones are represented; therefore, the results might not be representative of the U.S. population. Evidence suggests that adults living in wireless-only households tend to be younger and have lower incomes, and are more likely to be members of minority populations, which might result in either underestimates or overestimates. Second, responses are self-reported and not confirmed by review of medical records. Finally, the survey response rate was low, which increases the risk for response bias.

Policy changes in the Patient Protection and Affordable Care Act are expected to remove financial barriers to CRC screening by expanding insurance coverage and eliminating cost sharing in Medicare and private plans, but additional barriers remain (8). Evidence-based, systems-change interventions, including client and provider reminders to ensure test completion and receipt of follow-up care, have been shown by the Guide to Community Preventive Services* to increase CRC screening; however, these approaches have not been widely adopted in clinical

\footnotetext{
* Additional information available at http://www.thecommunityguide. org/index.html.
} 
practice. Physician recommendation remains an important but underutilized facilitator of CRC screening. Improving cancer screening benchmarks in clinical practice should be a high priority for new patient-care improvement models such as the patient-centered medical home (9). Case management approaches such as patient navigation models to maximize patient participation and ensure adequate follow-up also appear promising (10). Utah has used multiple approaches to improve its CRC screening prevalence. Reported use of CRC endoscopy increased from $32.1 \%$ in 1999 to $51.9 \%$ in 2005 through the use of small media (e.g., videos, letters, brochures, and flyers) and large media campaigns and by providing CRC screening tests (mainly FOBT) for those who could not afford it. ${ }^{\dagger}$

CDC's CRC screening program, funded in 2009, places emphasis on population-based approaches to increase CRC screening. ${ }^{\S}$ The program is based on the recommendations of the Guide to Community Preventive Services, which has identified evidencebased interventions to increase cancer screening in communities by targeting providers and the general population. Full implementation of these recommendations, including a focus on reaching disadvantaged populations, can achieve the goal of more complete population coverage.

Surveillance of cancer screening and diagnostic activities currently is limited to population surveys and is only collected every other year by BRFSS. Additional surveillance efforts might guide population-based outreach, identify and target unscreened populations, and ensure adequate follow-up (10). CDC and state and local health departments should develop and monitor centralized population-based registries of persons eligible for screening, provide appropriate outreach, and ensure adequate followup. These registries could be developed to track and promote screening awareness and subsequent utilization through communication media (e.g., telephone, mail, or electronic reminders) or use of peer outreach. Registries of underserved populations, including Medicaid enrollees and those without a regular provider, could be used to promote screening among persons in vulnerable populations at greater risk.

\footnotetext{
$\dagger^{\dagger}$ Additional information available at http://health.utah.gov/ucan/ partners/pub/pdfs/utahcancerplan080206.pdf.

$\$$ Available at http://www.cdc.gov/cancer/crccp.
}

FIGURE 1. Percentage of respondents aged 50-75 years who reported receiving a fecal occult blood test (FOBT) within 1 year or a lower endoscopy* within 10 years, by state - Behavioral Risk Factor Surveillance System (BRFSS), United States, $2008^{\dagger}$

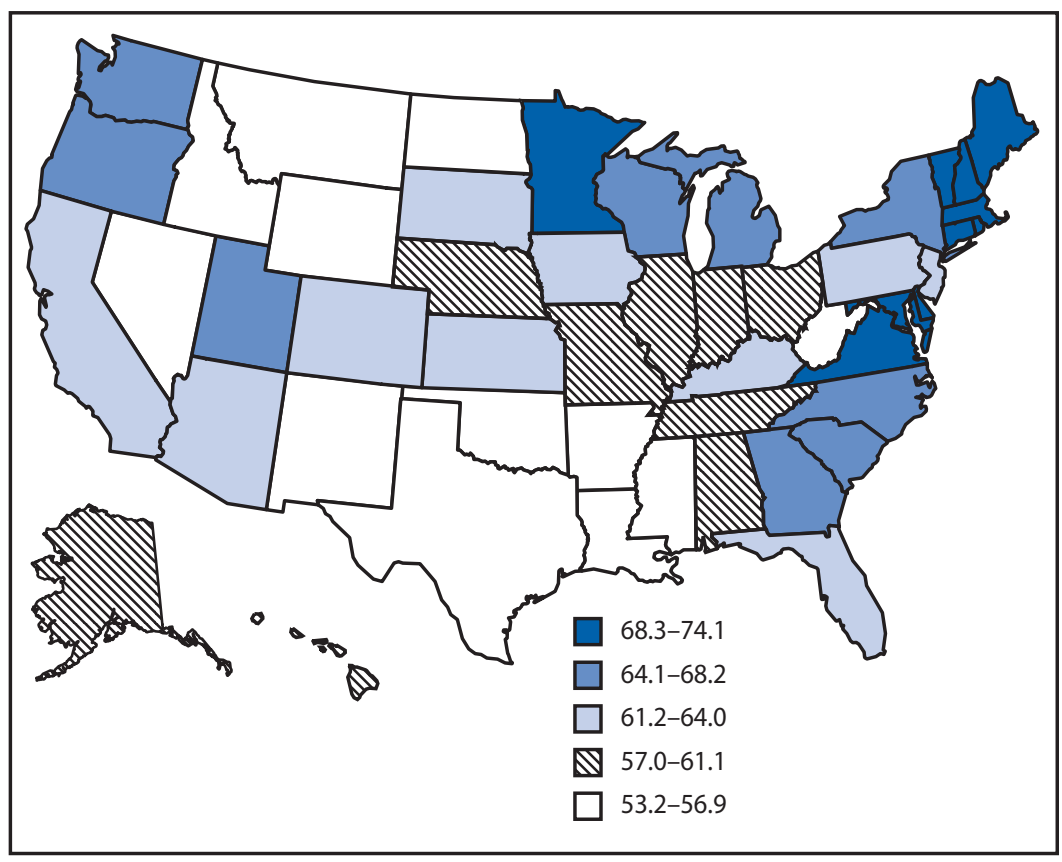

* Sigmoidoscopy or colonoscopy.

† Percentages standardized to the age distribution in the 2008 BRFSS survey.

FIGURE 2. Percentage of respondents aged $50-75$ years who reported receiving a fecal occult blood test (FOBT) within 1 year or a lower endoscopy* within 10 years Behavioral Risk Factor Surveillance System (BRFSS), United States, 2002, 2004, 2006, and $2008^{\dagger}$

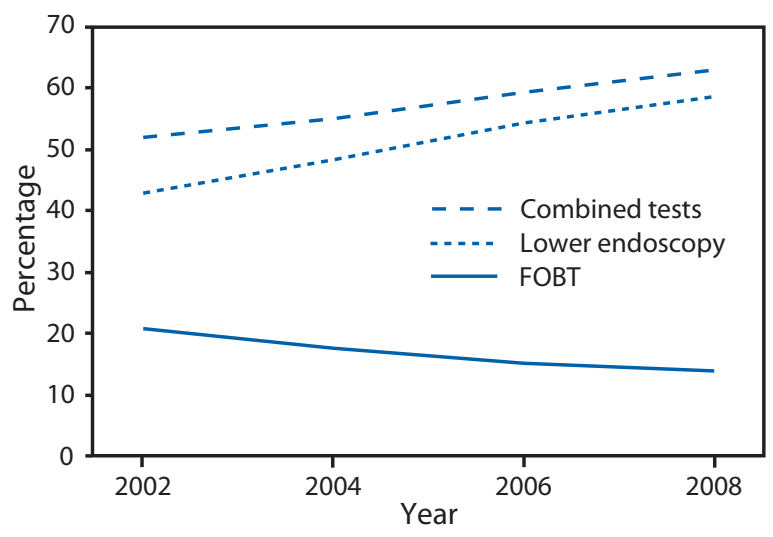

* Sigmoidoscopy or colonoscopy.

† Percentages standardized to the age distribution in the 2008 BRFSS survey. 


\section{Reported by}

LC Richardson, MD, SH Rim, MPH, M Plescia, MD; Div of Cancer Prevention and Control, National Center Chronic Disease Prevention and Health Promotion, $C D C$.

\section{References}

1. US Cancer Statistics Working Group. United States cancer statistics: 1999-2006 incidence and mortality web-based report. Atlanta, GA: US Department of Health and Human Services, CDC, and National Cancer Institute; 2010. Available at http://www.cdc.gov/uscs. Accessed June 23, 2010.

2. Winawer SJ, Zauber AG, Ho MN, et al. Prevention of colorectal cancer by colonoscopic polypectomy. The National Polyp Study Workgroup. N Engl J Med 1993;329:1977-81.

3. CDC. Use of colorectal cancer tests-United States, 2002, 2004, and 2006. MMWR 2008;57:253-8.

4. US Preventive Services Task Force. Screening for colorectal cancer. Rockville, MD: Agency for Healthcare Research and Quality; 2008. Available at http://www.ahrq.gov/clinic/ uspstf/uspscolo.htm. Accessed June 20, 2010.

5. CDC. Behavioral Risk Factor Surveillance System. Atlanta, GA: US Department of Health and Human Services, CDC; 2010. Available at http://www.cdc.gov/brfss. Accessed June 20, 2010.
6. American Cancer Society. Cancer prevention and early detection facts and figures 2010. Atlanta, GA: American Cancer Society; 2010. Available at http://www.cancer.org/research/ cancerfactsfigures/cancerpreventionearlydetectionfactsfigures/ index. Accessed July 6, 2010.

7. Edwards BK, Ward E, Kohler BA, et al. Annual report to the nation on the status of cancer, 1975-2006, featuring colorectal cancer trends and impact of interventions (risk factors, screening, and treatment) to reduce future rates. Cancer 2010;116:544-73.

8. The Patient Protection and Affordable Care Act. Pub. L. No. 111-148. Available at http://frwebgate.access.gpo.gov/ cgi-bin/getdoc.cgi?dbname $=111$ _cong_bills\&docid=f:h3590 enr.txt.pdf. Accessed June 20, 2010.

9. Wender RC, Altshuler M. Can the medical home reduce cancer morbidity and mortality? Prim Care 2009;36:845-58.

10. New York City Department of Health and Mental Hygiene. A practical guide to increasing screening colonoscopy: proven methods for health care facilities to prevent colorectal cancer deaths. New York, NY: New York City Department of Health and Mental Hygiene; 2006. Available at http://www.nyc.gov/ $\mathrm{html} /$ doh/downloads/pdf/cancer/cancer-colonoscopy-guide. pdf. Accessed June 20, 2010. 


\title{
Vital Signs: Breast Cancer Screening Among Women Aged 50-74 Years — United States, 2008
}

\begin{abstract}
On July 6, this report was posted as an MMWR Early Release on the MMWR website (http://www.cdc.gov/mmwr).
\end{abstract}

\section{ABSTRACT}

Background: Breast cancer remains the second leading cause of cancer deaths for women in the United States. Screening with treatment has lowered breast cancer mortality.

Methods: Every 2 years, CDC uses Behavioral Risk Factor Surveillance System data to estimate mammography prevalence in the United States. Up-to-date mammography prevalence is calculated for women aged 50-74 years who report they had the test in the preceding 2 years.

Results: For 2008, overall, age-adjusted, up-to-date mammography prevalence for U.S. women aged $50-74$ years was $81.1 \%$, compared with $81.5 \%$ in 2006 . Among the lowest prevalences reported were those by women aged 50-59 years $(79.9 \%)$, persons who did not finish high school (72.6\%), American Indian/Alaska Natives (70.4\%), those with annual household income $<\$ 15,000(69.4 \%)$, and those without health insurance (56.3\%). Highest mammography prevalence was among residents of the northeastern United States.

Conclusions: In recent years, mammography rates have plateaued. Critical gaps in screening remain for certain racial/ethnic groups and lower socioeconomic groups, and for the uninsured.

Implications for Public Health Practice: Health-care reform is likely to increase access by increasing insurance coverage and by reducing out-of-pocket costs for mammography screening. Widespread implementation of evidence-based interventions also will be needed to increase screening rates. These include patient and provider reminders to schedule a mammogram, use of small media (e.g., videos, letters, brochures, and flyers), one-on-one education of women, and reduction of structural barriers (e.g., more convenient hours and attention to language, health literacy, and cultural factors).

Breast cancer remains the most commonly diagnosed cancer and the second leading cause of cancer deaths among women in the United States. In 2006 (the most recent data available), approximately 191,410 women were diagnosed with invasive breast cancer, and 40,820 women died (1). The incidence and mortality have been declining since 1996 at a rate of approximately $2 \%$ per year (2), possibly as a result of widespread screening with mammography and the development of more effective therapies (3). Mammography use declined slightly in 2004, but rose again in $2006(4,5)$. This Vital Signs report updates mammography screening prevalence in the United States, using data from the 2008 Behavioral Risk Factor Surveillance System (BRFSS).

\section{Methods}

BRFSS is a state-based, random-digit-dialed telephone survey of the civilian, noninstitutionalized adult population that collects information on health risk behaviors, preventive health practices, and health-care access in the United States (๑). Every 2 years (even numbered years), adult female respondents are asked whether they have ever had a mammogram. Respondents who answer "yes" are then asked how long it has been since their last mammogram. For this report, breast cancer screening prevalence was calculated for women aged 50-74 years based on United States Preventive Services Task Force (USPSTF) recommendations, which considers women to be up-todate if they received a mammogram in the preceding 2 years ( 7 ). Respondents who refused to answer, had 
a missing answer, or answered "don't know/not sure" were excluded.

The median Council of American Survey and Research Organizations (CASRO) response rate was $53.3 \%$, and the median CASRO cooperation rate was $75.0 \%$ (6). Data were weighted to the age, sex, and racial and ethnic distribution of each state's adult population using intercensal estimates and were age-standardized to the 2008 BRFSS female population.

\section{Results}

In 2008, the BRFSS survey was administered to 414,509 respondents, of whom 120,095 were women aged 50-74 years. The age-adjusted prevalence of up-to-date mammography for women overall in the United States was $81.1 \%$ (Table). Among the lowest

TABLE. Percentage of women aged 50-74 years who reported receiving up-to-date* mammography, by selected characteristics - Behavioral Risk Factor Surveillance System (BRFSS), United States, $2008^{\dagger}$

\begin{tabular}{|c|c|c|c|}
\hline Characteristic & No. & $\%$ & $\left(95 \% \mathrm{Cl}^{\S}\right)$ \\
\hline Total & 117,450 & 81.1 & $(80.7-81.6)$ \\
\hline \multicolumn{4}{|l|}{ Age group (yrs) } \\
\hline $50-59$ & 52,421 & 79.9 & $(79.2-80.5)$ \\
\hline $60-69$ & 46,711 & 82.4 & $(81.8-83.0)$ \\
\hline $70-74$ & 18,318 & 82.7 & (81.7-83.7) \\
\hline \multicolumn{4}{|l|}{ Race } \\
\hline White & 101,245 & 81.4 & $(81.0-81.8)$ \\
\hline Black & 9,805 & 82.1 & (80.5-83.7) \\
\hline Asian/Pacific Islander & 1,665 & 80.4 & $(75.9-84.3)$ \\
\hline $\begin{array}{l}\text { American Indian/ } \\
\text { Alaska Native }\end{array}$ & 1,736 & 70.4 & $(65.6-74.7)$ \\
\hline Other & 2,257 & 77.0 & $(73.4-80.3)$ \\
\hline \multicolumn{4}{|l|}{ Ethnicity } \\
\hline Hispanic & 4,886 & 81.4 & (79.1-83.4) \\
\hline Non-Hispanic & 112,115 & 81.1 & $(80.7-81.5)$ \\
\hline \multicolumn{4}{|l|}{ Education level } \\
\hline$<$ High school & 10,323 & 72.6 & (70.6-74.5) \\
\hline High school graduate/GED? & 37,975 & 78.6 & $(77.8-79.3)$ \\
\hline Some college/tech school & 32,819 & 81.1 & $(80.3-81.8)$ \\
\hline College graduate & 36,177 & 86.2 & $(85.5-86.8)$ \\
\hline \multicolumn{4}{|l|}{ Annual household income (\$) } \\
\hline$<15,000$ & 12,744 & 69.4 & $(67.6-71.1)$ \\
\hline $15,000-34,999$ & 31,678 & 74.2 & $(73.2-75.3)$ \\
\hline $35,000-49,999$ & 16,382 & 82.0 & (80.8-83.0) \\
\hline $50,000-74,999$ & 17,098 & 84.8 & (83.9-85.8) \\
\hline$\geq 75,000$ & 23,059 & 87.9 & $(87.1-88.7)$ \\
\hline \multicolumn{4}{|l|}{ Health insurance } \\
\hline Yes & 107,780 & 83.8 & $(83.4-84.2)$ \\
\hline No & 9,536 & 56.3 & $(53.2-59.5)$ \\
\hline
\end{tabular}

prevalences reported were those by women aged 50-59 years $(79.9 \%)$, persons who did not finish high school (72.6\%), American Indian/Alaska Natives $(70.4 \%)$, those with annual household income $<\$ 15,000(69.4 \%)$, and those without health insurance $(56.3 \%)$. Mammography screening prevalence varied by state, with the highest mammography use in the northeastern United States. Among states, screening prevalence ranged from $72.1 \%$ in Nevada to $89.8 \%$ in Massachusetts (Figure 1). Nationally, up-to-date mammography screening increased from $77.5 \%$ in 1997 to $81.1 \%$ in 2008 (Figure 2).

\section{Conclusions and Comment}

After mammography was shown to be effective in lowering morbidity and mortality from breast cancer in the early 1990s, it was adopted rapidly for the early detection of breast cancer (3). However, as this Vital Signs report confirms, mammography utilization has leveled off in the last decade $(4,5)$. Other populationbased surveys have shown a similar plateau in rates. Results from the 2008 National Health Interview Survey indicate comparable mammography screening for women aged $50-64$ and $65-74$ years $(74.2 \%$ and $72.6 \%$, respectively)(4).

In 2000, the U.S. Department of Health and Human Services set a Healthy People 2010 target to increase to $70 \%$ the proportion of women aged $>40$ years who had a mammogram within the past 2 years.* The target was met in 2003 and exceeded by 11 percentage points in 2008. Nonetheless, approximately 7 million eligible women in the United States are not being screened regularly, and they remain at greater risk of death from breast cancer. One recent report estimated that as many as 560 breast cancer deaths could be prevented each year with each $5 \%$ increase in mammography (8). One successful program that reaches out to minority, low income, uninsured women is the National Breast and Cervical Cancer Early Detection Program. ${ }^{\dagger}$ The program has provided high quality screening, diagnostic and treatment services for the past 20 years.

Mammography utilization is influenced by multiple factors, including patient and provider characteristics, health-care norms, and access to and availability of health-care services. Similar to previous

\footnotetext{
*Additional information available at http://www.healthypeople.gov.

$\dagger$ Additional information available at http://www.cdc.gov/cancer/ nbccedp.
} 


\section{Key Points for the Public}

- One in five women aged $50-74$ is not up-to-date with mammograms.

- Over 40,000 U.S. women die each year from breast cancer.

- 560 deaths can be prevented each year for each 5\% increase in mammography.

- Additional information is available at http://www.cdc.gov/vitalsigns.

analyses, the analysis in this report found pockets of mammography underscreening among several large U.S. populations. For example, the screening rate varied considerably by geography and was lowest in west-central states, the states with the lowest population densities ${ }^{\S}$ as well as the states with the fewest mammography facilities. 9 A study from Texas highlighted the association between mammography supply and mammography use at the county level. Counties with no mammography units had the lowest mammography utilization (9).

The passage of the Patient Protection and Affordability Act should remove the financial barrier to mammography screening by expanding coverage and eliminating cost sharing in Medicare and private plans; however, barriers remain. For example, in 2008 the difference in mammography prevalence between women with and without health insurance was $27.5 \%$. Even among women with health insurance, $16.2 \%$ had not received mammography in the preceding 2 years. Similar differences in receipt of mammography by insurance status were noted in a 2009 study (9). These findings suggest new roles for public health to improve screening through increased education of women and providers, and through additional targeted outreach to underscreened groups including lower SES, uninsured and select minority groups. Several evidence-based interventions are recommended by the Guide to Community Preventive Services to increase mammography screening in

\footnotetext{
$\$$ Additional information available at http://www.frontierus.org/ 2000update.htm and http://www.shepscenter.unc.edu/rural/maps/ Frontier_counties07.pdf.

SAdditional information available at http://www.gao.gov/new.items/ d06724.pdf.
}

FIGURE 1. Percentage of women aged 50-74 years who reported receiving up-to-date* mammography, by state - Behavioral Risk Factor Surveillance System (BRFSS), United States, $2008^{\dagger}$

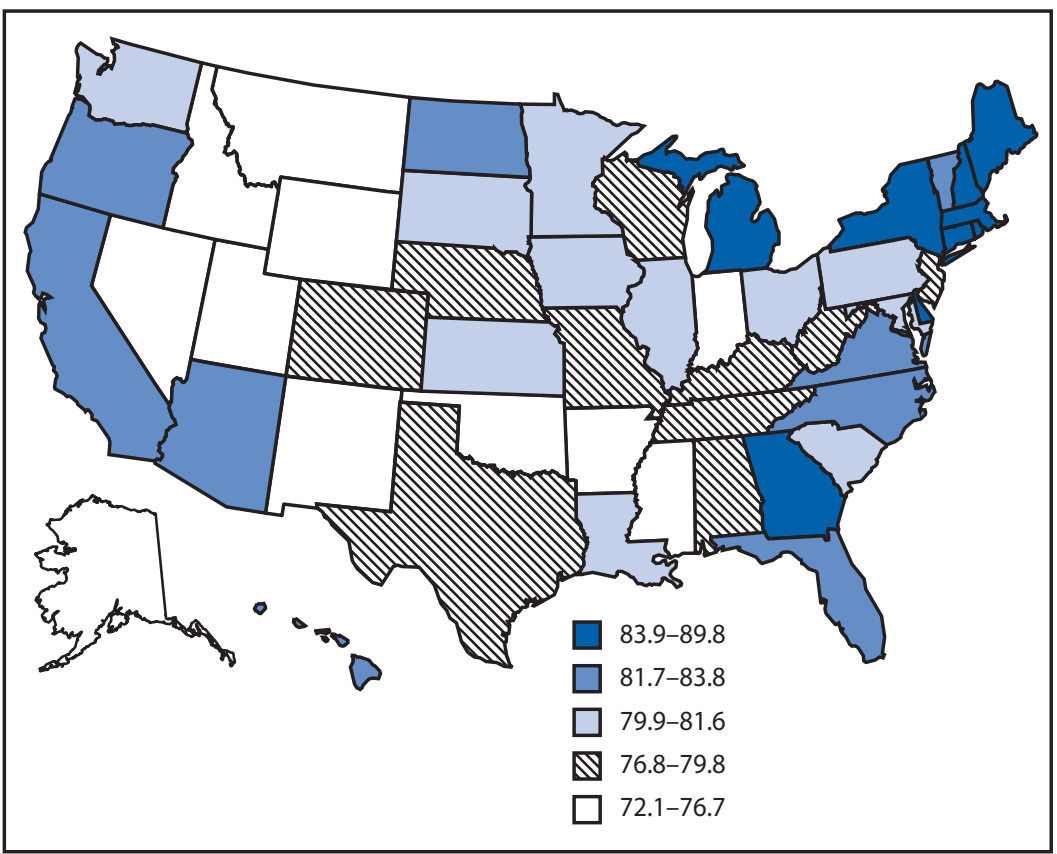

* Within the preceding 2 years.

† Percentages standardized to the age distribution in the 2008 BRFSS survey.

FIGURE 2. Percentage of women aged $50-74$ years who reported receiving up-to-date* mammography Behavioral Risk Factor Surveillance System (BRFSS), United States, 1997, 1998, 1999, 2000, 2002, 2004, 2006, and $2008^{\dagger}$

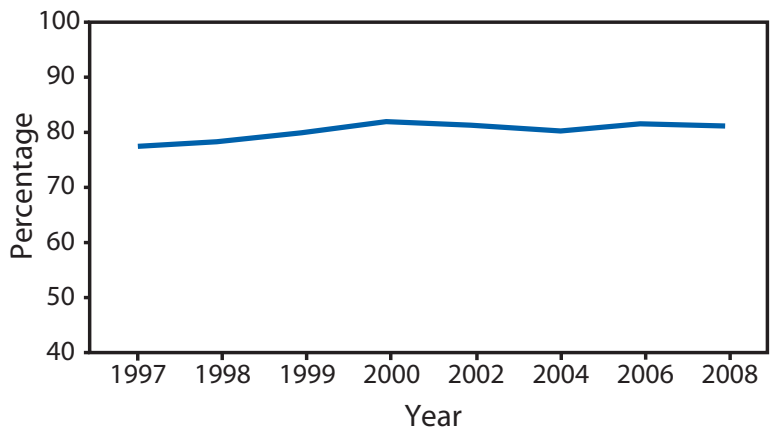

* Within the preceding 2 years.

† Percentages standardized to the age distribution in the 2008 BRFSS survey.

communities. $^{* *}$ These include sending client reminders to women, using small media (e.g., videos, letters, flyers, and brochures), and reducing structural barriers (e.g., providing more convenient hours and increasing

\footnotetext{
** Additional information available at http://www.thecommunity guide.org/index.htm.
} 
attention to language, health literacy, and cultural factors). Surveillance with targeted outreach, case management, and quality assurance through systems change are productive future roles for public health agencies to improve the delivery of clinical preventive services in the era of health reform.

The findings in this report are subject to at least three limitations. First, because BRFSS is a telephone survey of residential households, only women in households with landline telephones participated; therefore, the results might not be representative of all women. Second, responses are self-reported and not confirmed by review of medical records. Finally, the survey response rate was low, which increases the risk for response bias.

Many factors influence a woman's intent and ability to access screening services, including socioeconomic status, awareness of the benefits of screening, and mammography acceptability and availability (10). However, the most common reason women give for not having a mammogram is that no one recommended the test; therefore, health-care providers have the most important role in increasing the prevalence of up-to-date mammography among women in the United States (10).

\section{Reported by}

LC Richardson, MD, SH Rim, MPH, M Plescia, MD, Div of Cancer Prevention and Control, National Center for Chronic Disease Prevention and Health Promotion, $C D C$.

\section{References}

1. US Cancer Statistics Working Group. United States cancer statistics: 1999-2006 incidence and mortality web-based report. Atlanta, GA: US Department of Health and Human Services, CDC, and National Cancer Institute; 2010. Available at: http://www.cdc.gov/uscs. Accessed June 23, 2010.

2. Edwards BK, Ward E, Kohler BA, et al. Annual report to the nation on the status of cancer, 1975-2006, featuring colorectal cancer trends and impact of interventions (risk factors, screening, and treatment) to reduce future rates. Cancer 2010;116:544-73.

3. Berry DA, Cronin KA, Plevritis SK, et al. Cancer Intervention and Surveillance Modeling Network (CISNET) collaborators. Effect of screening and adjuvant therapy on mortality from breast cancer. N Engl J Med 2005 Oct 27;353:1784-92.

4. CDC. Health, United States, 2009: with special feature on medical technology. Hyattsville, MD: US Department of Health and Human Services, CDC, National Center for Health Statistics; 2010. Available at http://www.cdc.gov/ nchs/data/hus/hus09.pdf. Accessed June 20, 2010.

5. Miller JW, King JB, Ryerson AB, Eheman CR, White MC. Mammography use from 2000 to 2006: state-level trends with corresponding breast cancer incidence rates. Am J Roentgenol 2009;192:352-60.

6. CDC. Behavioral Risk Factor Surveillance System. Atlanta, GA: US Department of Health and Human Services, CDC; 2010. Available at http://www.cdc.gov/brfss. Accessed June 20, 2010.

7. US Preventive Services Task Force. Screening for breast cancer: recommendation statement. Rockville, MD: Agency for Healthcare Research and Quality; 2009. Available at http:// www.ahrq.gov/clinic/uspstf09/breastcancer/brcanrs.htm. Accessed June 20, 2010.

8. Farley TA, Dalal MA, Mostashari F, Frieden TR. Deaths preventable in the U.S. by improvements in use of clinical preventive services. Am J Prev Med 2010;38:600-9.

9. Elting LS, Cooksley CD, Bekele BN, et al. Mammography capacity impact on screening rates and breast cancer stage at diagnosis. Am J Prev Med 2009;37:102-8.

10. Schueler KM, Chu PW, Smith-Bindman R. Factors associated with mammography utilization: a systematic quantitative review of the literature. J Womens Health 2008;17:1477-98. 


\section{Pertussis - California, January-June 2010}

The number of pertussis cases reported to the California Department of Public Health (CDPH) has increased substantially during 2010 . The increase in cases was first noted in late March among patients admitted to a children's hospital. During January 1June 30, 2010, a total of 1,337 cases were reported, a $418 \%$ increase from the 258 cases reported during the same period in 2009. All cases either met the Council of State and Territorial Epidemiologists definitions for confirmed or probable pertussis or had an acute cough illness and Bordetella pertussis-specific nucleic acid detected by polymerase chain reaction from nasopharyngeal specimens (1).

During January-June in California, the incidence of pertussis was 3.4 cases per 100,000 population. County rates ranged from zero to 76.9 cases per 100,000 (median: 2.0 cases). By age group, incidence was highest $(38.5$ cases per 100,000) among infants aged $<1$ year; $89 \%$ of cases were among infants aged $<6$ months, who are too young to be fully immunized. Incidence among children aged 7-9 years and $10-18$ years was 10.1 cases and 9.3 cases per 100,000 , respectively.

Of 634 case reports with available data, 105 (16.6\%) patients were hospitalized, of whom 66 $(62.9 \%)$ were aged $<3$ months. Incidence among Hispanic infants ( 49.8 cases per 100,000) was higher than among other racial/ethnic populations. Five deaths were reported, all in previously healthy Hispanic infants aged $<2$ months at disease onset; none had received any pertussis-containing vaccines.

The incidence of pertussis is cyclical, with peaks occurring every 3-5 years in the United States (2). The last peak was in 2005, when approximately 25,000 cases were reported nationally and approximately 3,000 cases in California, including eight deaths in infants aged $<3$ months. If the rates from the first half of the year persist throughout 2010, California would have its highest annual rate of pertussis reported since 1963 and the most cases reported since 1958.

$\mathrm{CDPH}$ is attempting to prevent transmission of pertussis to vulnerable infants (3) by disseminating educational materials and clinical guidance, raising community awareness, and offering free tetanus, diphtheria, and acellular pertussis (Tdap) vaccine to birthing hospitals and local health departments to support postpartum vaccination of mothers and close contacts of newborns.

\section{Reported by}

$K$ Winter, $M P H, K$ Harriman, $P h D, R$ Schechter, $M D$, E Yamada, MD, J Talarico, DO, G Chavez, MD, California Dept of Public Health.

\section{References}

1. CDC. Manual for the surveillance of vaccine-preventable diseases. Atlanta, GA: US Department of Health and Human Services, CDC; 2008.

2. Farizo KM, Cochi SL, Zell ER, Brink EW, Wassilak SG, Patriarca PA. Epidemiologic features of pertussis in the United States, 1980-1989. Clin Infect Dis 1992;14:708-19.

3. CDC. Prevention of pertussis, tetanus, and diphtheria among pregnant and postpartum women and their infants. MMWR 2008;57(No. RR-4).

\section{Salmonella Newport Infections Associated with Consumption of Unpasteurized Milk - Utah, April-June 2010}

On April 29, 2010, the Utah Department of Health (UDOH) was notified of three cases of Salmonella enterica serotype Newport infection. The three patients recently had consumed unpasteurized milk purchased from a store in northern Utah (store A). In Utah, unpasteurized milk can be sold legally at licensed dairies or by licensed dairies at dairy-owned retail stores meeting specific requirements (1). A central Utah dairy licensed to sell unpasteurized milk (dairy A) owns and sells unpasteurized milk at store A and a second northern Utah store (store B). By May 3, 2010, three additional patients with $S$. Newport infections had been reported; all recently had consumed unpasteurized milk purchased from store A. UDOH notified the Utah Department of Agriculture and Food (UDAF) of the suspected association between illness and unpasteurized milk consumption, and UDAF suspended sales of unpasteurized milk at the two stores on May 3, 2010.

During April 29-June 3, 2010, a total of 10 $S$. Newport cases were reported to UDOH; all 10 patients had consumed unpasteurized milk from store A (seven patients) or store B (three patients). The patients ranged in age from 2 to 56 years (median: 21 years); six were female. One patient was 
hospitalized. Isolates from all 10 patients were identified as indistinguishable by two-enzyme pulsed-field gel electrophoresis (PFGE), with pattern combination UTJJPX01.098/UTJJPA26.009, and were sensitive to routinely used antibiotics. Cultures of frozen, unpasteurized milk samples stored at dairy A from batches of milk sold during the outbreak period yielded $S$. Newport isolates indistinguishable by PFGE from the outbreak strain. An inspection of dairy A on May 7, 2010, did not reveal any obvious sources of contamination.

On May 12, 2010, on the basis of coliform test results within legal limits, the dairy was permitted to resume sales of unpasteurized milk. Ongoing testing includes monthly screening for Salmonella spp. in retail samples of unpasteurized milk. As of June 21, 2010, no additional cases had been reported to UDOH. Consumption of unpasteurized dairy products poses a risk for foodborne illness (2), and consumers of unpasteurized milk should be aware of this risk.

\section{Reported by}

JM Hall, MPH, RT Rolfs, MD, RK Herlihy, MD, MPS Dimond, MPH, Bur of Epidemiology, Utah Dept of Health; J Holbrook, MPH, Utah County Health Dept; LH Smith, JM Wagner, Unified State Laboratories: Public Health, Utah Dept of Health; RW Clark, MPH, Utah Dept of Agriculture and Food. WA Lanier, DVM, EIS Officer, $C D C$.

\section{References}

1. Utah Dairy Act. Utah Code sec 4-3-14. Available at http://le. utah.gov/-code/TITLE04/htm/04_03_001400.htm. Accessed July 1, 2010.

2. Oliver SP, Boor KJ, Murphy SC, Murinda SE. Food safety hazards associated with consumption of raw milk. Foodborne Path Dis 2009;6:793-806.

\section{Announcement}

\section{MMWR on Facebook and Twitter}

$M M W R$ reports now can be accessed on social networking websites Facebook and Twitter. Readers can download and comment on $M M W R$ weekly reports, recommendations and reports, surveillance summaries, and podcasts from the MMWR website. Readers can follow $M M W R$ on Facebook by visiting http://www.facebook.com/cdcmmwr, and on Twitter by visiting http://www.twitter.com/cdcmmwr. 


\section{Never-Married Females and Males Aged 15-19 Years Who Have Ever Had Sexual Intercourse* — National Survey of Family Growth, United States, 1988-2008}

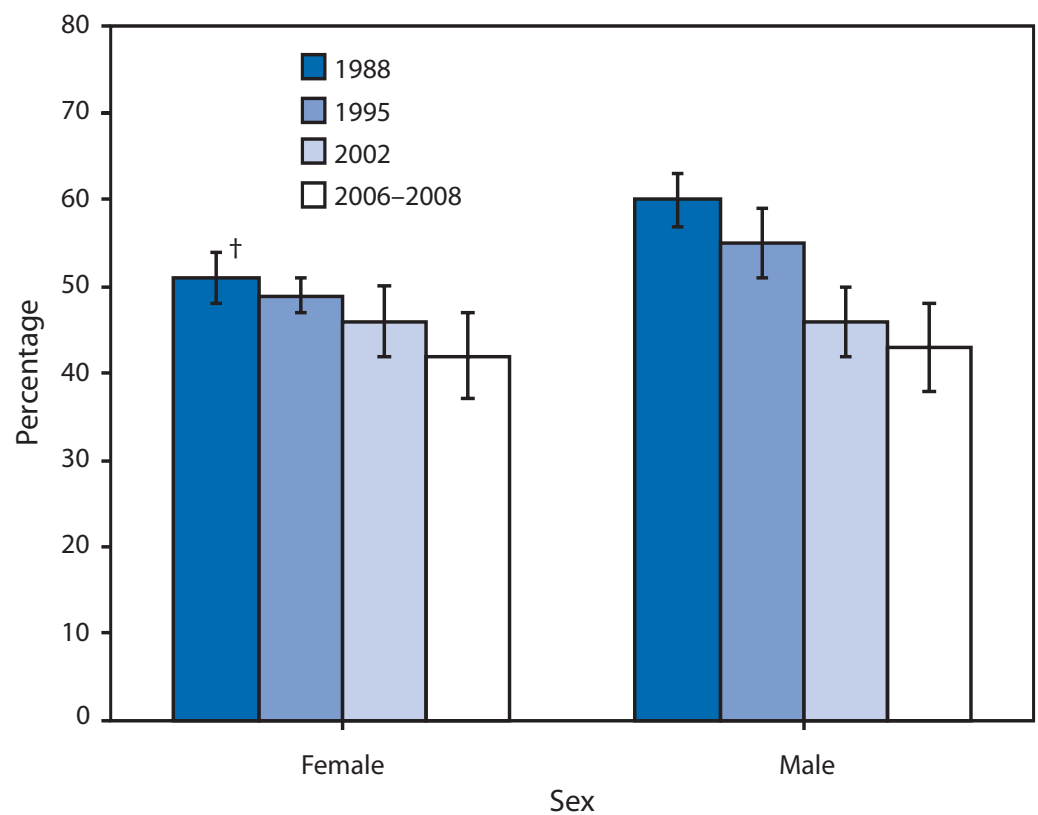

\footnotetext{
* Based on responses by females to the question, "At any time in your life have you ever had sexual intercourse with a man, that is, made love, had sex, or gone all the way?" and by males to the question, "Have you ever had sexual intercourse with a female (sometimes this is called making love, having sex, or going all the way)?"

† $95 \%$ confidence interval.
}

From 1988 to 2006-2008, the percentage of never-married teenage females (ages 15-19 years) who ever had sexual intercourse declined from $51 \%$ to $42 \%$, and the percentage for never-married teenage males declined from $60 \%$ to $43 \%$. In 1988 , teenage males were more likely than teenage females to have ever have had sexual intercourse, but by 2006-2008, the percentages were equivalent.

Source: Abma JC, Martinez GM, Copen CE. Teenagers in the United States: sexual activity, contraceptive use, and childbearing, National Survey of Family Growth, 2006-2008. Vital Health Stat 2010; 23(30). Available at http://www.cdc.gov/nchs/data/series/sr_23/sr23_030.pdf. 
Notifiable Diseases and Mortality Tables

TABLE I. Provisional cases of infrequently reported notifiable diseases $(<1,000$ cases reported during the preceding year) - United States, week ending July 3, 2010 (26th week)*

\begin{tabular}{|c|c|c|c|c|c|c|c|c|c|}
\hline \multirow[b]{2}{*}{ Disease } & \multirow{2}{*}{$\begin{array}{l}\text { Current } \\
\text { week }\end{array}$} & \multirow{2}{*}{$\begin{array}{l}\text { Cum } \\
2010\end{array}$} & \multirow{2}{*}{$\begin{array}{c}\text { 5-year } \\
\text { weekly } \\
\text { average }^{\dagger}\end{array}$} & \multicolumn{5}{|c|}{$\begin{array}{l}\text { Total cases reported } \\
\text { for previous years }\end{array}$} & \multirow{2}{*}{$\begin{array}{c}\text { States reporting cases } \\
\text { during current week (No.) }\end{array}$} \\
\hline & & & & 2009 & 2008 & 2007 & 2006 & 2005 & \\
\hline Anthrax & - & - & - & 1 & - & 1 & 1 & - & \\
\hline Botulism, total & - & 35 & 3 & 118 & 145 & 144 & 165 & 135 & \\
\hline foodborne & - & 4 & 0 & 10 & 17 & 32 & 20 & 19 & \\
\hline infant & - & 23 & 2 & 83 & 109 & 85 & 97 & 85 & \\
\hline other (wound and unspecified) & - & 8 & 1 & 25 & 19 & 27 & 48 & 31 & \\
\hline Brucellosis & - & 53 & 2 & 115 & 80 & 131 & 121 & 120 & \\
\hline Chancroid & 1 & 27 & 0 & 28 & 25 & 23 & 33 & 17 & NY (1) \\
\hline Cholera & - & 2 & 0 & 10 & 5 & 7 & 9 & 8 & \\
\hline Cyclosporiasis $^{\S}$ & 8 & 54 & 10 & 141 & 139 & 93 & 137 & 543 & NY (1), FL (7) \\
\hline Diphtheria & - & - & - & - & - & - & - & - & \\
\hline \multicolumn{10}{|l|}{ Domestic arboviral diseases ${ }^{\S}$, ?ी: } \\
\hline California serogroup virus disease & - & - & 2 & 55 & 62 & 55 & 67 & 80 & \\
\hline Eastern equine encephalitis virus disease & - & 1 & 0 & 4 & 4 & 4 & 8 & 21 & \\
\hline Powassan virus disease & - & 1 & 0 & 6 & 2 & 7 & 1 & 1 & \\
\hline St. Louis encephalitis virus disease & - & - & 1 & 12 & 13 & 9 & 10 & 13 & \\
\hline Western equine encephalitis virus disease & - & - & - & - & - & - & - & - & \\
\hline \multicolumn{10}{|l|}{ Haemophilus influenzae, ${ }^{* *}$ invasive disease (age $<5 \mathrm{yrs}$ ): } \\
\hline serotype b & - & 7 & 0 & 35 & 30 & 22 & 29 & 9 & \\
\hline nonserotype b & - & 94 & 4 & 236 & 244 & 199 & 175 & 135 & \\
\hline unknown serotype & 3 & 113 & 3 & 178 & 163 & 180 & 179 & 217 & $\mathrm{PA}(1), \mathrm{OH}(2)$ \\
\hline Hansen disease $\mathrm{\S}^{\S}$ & 1 & 18 & 2 & 103 & 80 & 101 & 66 & 87 & $\mathrm{MD}(1)$ \\
\hline Hantavirus pulmonary syndrome $e^{\S}$ & - & 4 & 1 & 20 & 18 & 32 & 40 & 26 & \\
\hline Hemolytic uremic syndrome, postdiarrheal ${ }^{\S}$ & 3 & 70 & 7 & 242 & 330 & 292 & 288 & 221 & NY (2), FL (1) \\
\hline HIV infection, pediatric (age $<13 \mathrm{yrs})^{\dagger+}$ & - & - & 1 & - & - & - & - & 380 & \\
\hline Influenza-associated pediatric mortality ${ }^{\S}, \S \S$ & - & 54 & 2 & 359 & 90 & 77 & 43 & 45 & \\
\hline Listeriosis & 6 & 283 & 17 & 852 & 759 & 808 & 884 & 896 & PA (1), OH (1), OK (1), CO (1), WA (1), OR (1) \\
\hline Measles & - & 28 & 4 & 71 & 140 & 43 & 55 & 66 & \\
\hline \multicolumn{10}{|l|}{ Meningococcal disease, invasive ${ }^{* * *}$ : } \\
\hline$A, C, Y$, and $W-135$ & 1 & 132 & 5 & 301 & 330 & 325 & 318 & 297 & CT (1) \\
\hline serogroup B & 2 & 62 & 4 & 174 & 188 & 167 & 193 & 156 & NY (1), TX (1) \\
\hline other serogroup & 1 & 6 & 0 & 23 & 38 & 35 & 32 & 27 & OK (1) \\
\hline unknown serogroup & 5 & 206 & 11 & 482 & 616 & 550 & 651 & 765 & NE (1), FL (1), OR (1), CA (2) \\
\hline Mumps & 5 & 2,064 & 21 & 1,991 & 454 & 800 & 6,584 & 314 & NY (5) \\
\hline Novel influenza A virus infections ${ }^{\text {t†† }}$ & - & 1 & 0 & 43,771 & 2 & 4 & NN & NN & \\
\hline Plague & - & - & 0 & 8 & 3 & 7 & 17 & 8 & \\
\hline Poliomyelitis, paralytic & - & - & - & 1 & - & - & - & 1 & \\
\hline Polio virus Infection, nonparalytic ${ }^{\S}$ & - & - & - & - & - & - & NN & NN & \\
\hline Psittacosis $\varsigma^{\S}$ & - & 4 & 0 & 9 & 8 & 12 & 21 & 16 & \\
\hline Q fever, total ${ }^{\S}, \S \S \S$ & 1 & 47 & 4 & 113 & 120 & 171 & 169 & 136 & \\
\hline acute & 1 & 36 & 2 & 93 & 106 & - & - & - & $\mathrm{FL}(1)$ \\
\hline chronic & - & 11 & 0 & 20 & 14 & - & - & - & \\
\hline Rabies, human & - & 1 & 0 & 4 & 2 & 1 & 3 & 2 & \\
\hline Rubella ติศึ & 1 & 4 & 0 & 3 & 16 & 12 & 11 & 11 & $C A(1)$ \\
\hline Rubella, congenital syndrome & - & - & - & 2 & - & - & 1 & 1 & \\
\hline SARS-CoV ${ }^{\S}, * * * *$ & - & - & - & - & - & - & - & - & \\
\hline Smallpox ${ }^{\S}$ & - & - & - & - & - & - & - & - & \\
\hline Streptococcal toxic-shock syndrome $e^{\S}$ & - & 91 & 2 & 162 & 157 & 132 & 125 & 129 & \\
\hline Syphilis, congenital (age $<1 \mathrm{yr})^{\mathrm{t+ \dagger}}$ & - & 80 & 8 & 423 & 431 & 430 & 349 & 329 & \\
\hline Tetanus & - & 1 & 1 & 18 & 19 & 28 & 41 & 27 & \\
\hline Toxic-shock syndrome (staphylococcal) ${ }^{\S}$ & 1 & 45 & 2 & 74 & 71 & 92 & 101 & 90 & MI (1) \\
\hline Trichinellosis & - & 1 & 1 & 13 & 39 & 5 & 15 & 16 & \\
\hline Tularemia & 6 & 22 & 5 & 93 & 123 & 137 & 95 & 154 & IN (2), MO (2), NE (2) \\
\hline Typhoid fever & 6 & 164 & 6 & 399 & 449 & 434 & 353 & 324 & MD (1), NV (1), WA (1), CA (3) \\
\hline Vancomycin-intermediate Staphylococcus aureus ${ }^{\S}$ & 8 & 50 & 1 & 78 & 63 & 37 & 6 & 2 & $\mathrm{NY}(2), \mathrm{OH}(1), \mathrm{MO}(4), \mathrm{FL}(1)$ \\
\hline Vancomycin-resistant Staphylococcus aureus ${ }^{\S}$ & - & 1 & - & 1 & - & 2 & 1 & 3 & \\
\hline Vibriosis (noncholera Vibrio species infections) ${ }^{\S}$ & 16 & 162 & 8 & 790 & 588 & 549 & NN & NN & MD (4), SC (1), GA (1), FL (5), WA (4), CA (1) \\
\hline Viral hemorrhagic fever ${ }^{\S \S \S}$ & - & 1 & - & NN & $\mathrm{NN}$ & NN & NN & NN & \\
\hline Yellow fever & - & - & - & - & - & - & - & - & \\
\hline
\end{tabular}

See Table I footnotes on next page. 
TABLE I. (Continued) Provisional cases of infrequently reported notifiable diseases $(<1,000$ cases reported during the preceding year) - United States, week ending July 3, 2010 (26th week)*

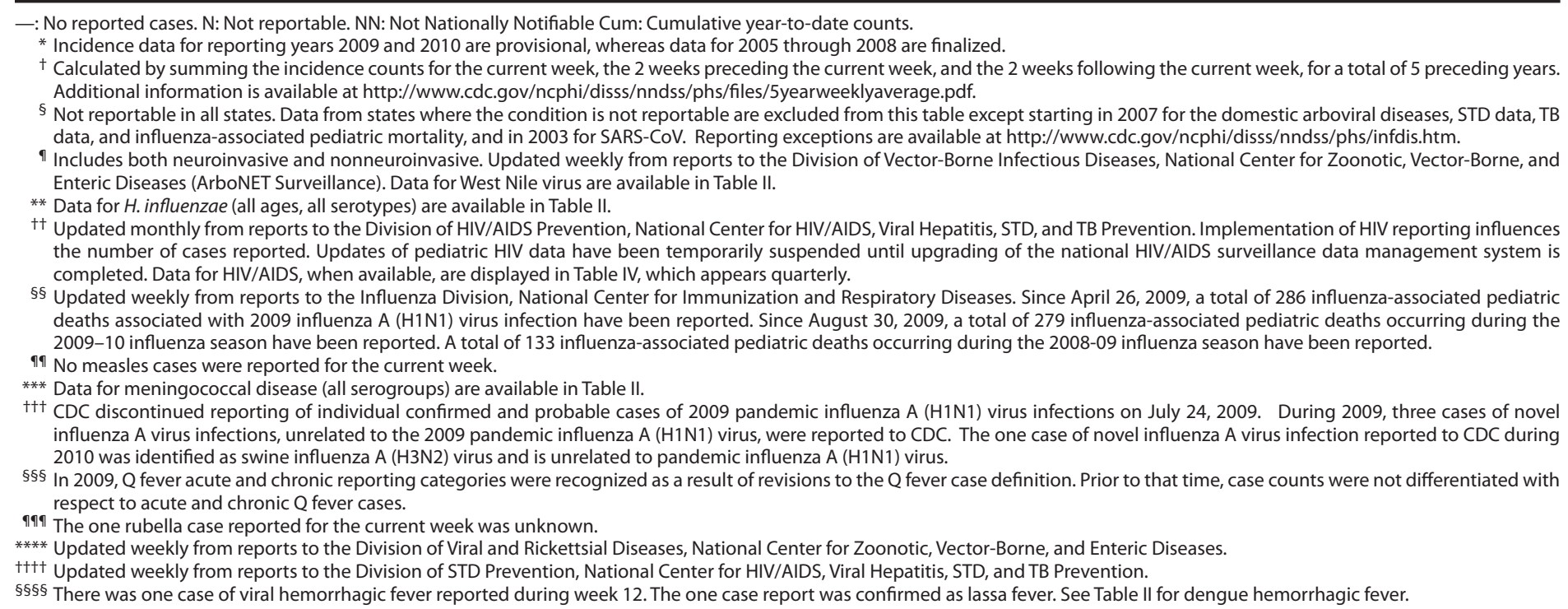

FIGURE I. Selected notifiable disease reports, United States, comparison of provisional 4-week totals July 3, 2010, with historical data

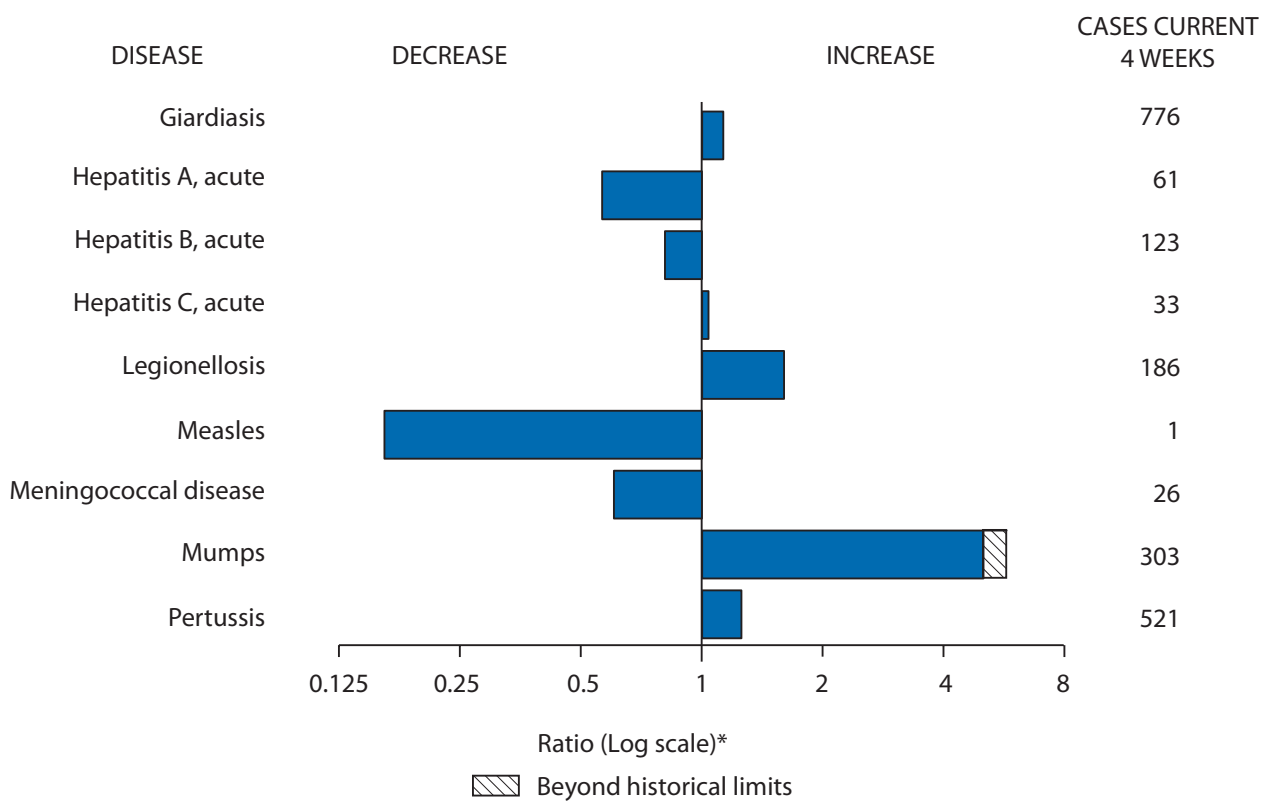

\footnotetext{
* Ratio of current 4-week total to mean of 15 4-week totals (from previous, comparable, and subsequent 4-week periods for the past 5 years). The point where the hatched area begins is based on the mean and two standard deviations of these 4-week totals.
}

Notifiable Disease Data Team and $\mathbf{1 2 2}$ Cities Mortality Data Team
\[ \begin{array}{ll}\text { Patsy A. Hall-Baker } \\ \text { Deborah A. Adams } & \text { Rosaline Dhara } \\ \text { Willie J. Anderson } & \text { Pearl C. Sharp } \\ \text { Jose Aponte } & \text { Michael S. Wodajo } \\ \text { Lenee Blanton } & \end{array} \]


TABLE II. Provisional cases of selected notifiable diseases, United States, weeks ending July 3, 2010, and July 4, 2009 (26th week)*

\begin{tabular}{|c|c|c|c|c|c|c|c|c|c|c|}
\hline \multirow[b]{3}{*}{ Reporting area } & \multicolumn{5}{|c|}{ Chlamydia trachomatis infection } & \multicolumn{5}{|c|}{ Cryptosporidiosis } \\
\hline & \multirow{2}{*}{$\begin{array}{c}\text { Current } \\
\text { week }\end{array}$} & \multicolumn{2}{|c|}{ Previous 52 weeks } & \multirow{2}{*}{$\begin{array}{l}\text { Cum } \\
2010\end{array}$} & \multirow{2}{*}{$\begin{array}{l}\text { Cum } \\
2009\end{array}$} & \multirow{2}{*}{$\begin{array}{c}\text { Current } \\
\text { week }\end{array}$} & \multicolumn{2}{|c|}{ Previous 52 weeks } & \multirow{2}{*}{$\begin{array}{l}\text { Cum } \\
2010\end{array}$} & \multirow{2}{*}{$\begin{array}{l}\text { Cum } \\
2009\end{array}$} \\
\hline & & Med & Max & & & & Med & Max & & \\
\hline United States & 10,018 & 22,061 & 26,080 & 523,942 & 625,532 & 84 & 116 & 284 & 2,558 & 2,678 \\
\hline $\begin{array}{l}\text { New England } \\
\text { Connecticut } \\
\text { Maine }^{\dagger} \\
\text { Massachusetts } \\
\text { New Hampshire } \\
\text { Rhode Island } \\
\text { Vermont }^{\dagger}\end{array}$ & $\begin{array}{r}640 \\
39 \\
445 \\
57 \\
81 \\
18\end{array}$ & $\begin{array}{r}743 \\
210 \\
49 \\
395 \\
38 \\
70 \\
23\end{array}$ & $\begin{array}{r}1,396 \\
736 \\
75 \\
638 \\
122 \\
130 \\
63\end{array}$ & $\begin{array}{r}18,838 \\
4,023 \\
1,229 \\
10,087 \\
1,121 \\
1,773 \\
605\end{array}$ & $\begin{array}{r}19,888 \\
5,874 \\
1,257 \\
9,413 \\
1,051 \\
1,694 \\
599\end{array}$ & $\begin{array}{l}\frac{2}{1} \\
- \\
- \\
-1\end{array}$ & $\begin{array}{l}6 \\
0 \\
1 \\
1 \\
1 \\
0 \\
1\end{array}$ & $\begin{array}{r}40 \\
36 \\
4 \\
15 \\
6 \\
8 \\
9\end{array}$ & $\begin{array}{r}130 \\
36 \\
28 \\
28 \\
7 \\
31\end{array}$ & $\begin{array}{r}173 \\
38 \\
18 \\
51 \\
27 \\
4 \\
35\end{array}$ \\
\hline $\begin{array}{l}\text { Mid. Atlantic } \\
\text { New Jersey } \\
\text { New York (Upstate) } \\
\text { New York City } \\
\text { Pennsylvania }\end{array}$ & $\begin{array}{r}2,438 \\
380 \\
505 \\
993 \\
560\end{array}$ & $\begin{array}{r}3,182 \\
440 \\
657 \\
1,186 \\
865\end{array}$ & $\begin{array}{r}4,619 \\
624 \\
2,530 \\
2,144 \\
1,089\end{array}$ & $\begin{array}{l}82,008 \\
10,831 \\
16,454 \\
31,788 \\
22,935\end{array}$ & $\begin{array}{l}77,902 \\
12,395 \\
14,415 \\
29,326 \\
21,766\end{array}$ & $\frac{16}{\frac{1}{15}}$ & $\begin{array}{r}15 \\
0 \\
3 \\
1 \\
9\end{array}$ & $\begin{array}{r}38 \\
5 \\
16 \\
5 \\
19\end{array}$ & $\begin{array}{r}291 \\
63 \\
27 \\
201\end{array}$ & $\begin{array}{r}302 \\
21 \\
64 \\
39 \\
178\end{array}$ \\
\hline $\begin{array}{l}\text { E.N. Central } \\
\text { Illinois } \\
\text { Indiana } \\
\text { Michigan } \\
\text { Ohio } \\
\text { Wisconsin }\end{array}$ & $\begin{array}{l}910 \\
\overline{-} \\
596 \\
136 \\
178\end{array}$ & $\begin{array}{r}3,409 \\
712 \\
296 \\
888 \\
966 \\
402\end{array}$ & $\begin{array}{r}4,413 \\
1,322 \\
602 \\
1,417 \\
1,077 \\
494\end{array}$ & $\begin{array}{r}73,093 \\
9,334 \\
6,194 \\
24,475 \\
23,026 \\
10,064\end{array}$ & $\begin{array}{r}101,723 \\
30,974 \\
11,876 \\
23,730 \\
24,447 \\
10,696\end{array}$ & $\begin{array}{l}17 \\
- \\
6 \\
7 \\
4\end{array}$ & $\begin{array}{r}28 \\
3 \\
4 \\
6 \\
7 \\
8\end{array}$ & $\begin{array}{r}73 \\
8 \\
11 \\
11 \\
16 \\
39\end{array}$ & $\begin{array}{r}610 \\
71 \\
76 \\
137 \\
179 \\
147\end{array}$ & $\begin{array}{r}650 \\
65 \\
128 \\
115 \\
178 \\
164\end{array}$ \\
\hline $\begin{array}{l}\text { W.N. Central } \\
\text { lowa } \\
\text { Kansas } \\
\text { Minnesota } \\
\text { Missouri } \\
\text { Nebraska } \\
\text { North Dakota } \\
\text { South Dakota }\end{array}$ & $\begin{array}{r}225 \\
15 \\
- \\
169 \\
- \\
41\end{array}$ & $\begin{array}{r}1,313 \\
181 \\
193 \\
271 \\
493 \\
95 \\
34 \\
46\end{array}$ & $\begin{array}{r}1,711 \\
299 \\
571 \\
337 \\
638 \\
237 \\
93 \\
82\end{array}$ & $\begin{array}{r}31,707 \\
4,929 \\
4,554 \\
6,508 \\
12,399 \\
2,322 \\
995 \\
\end{array}$ & $\begin{array}{r}35,064 \\
4,925 \\
4,816 \\
7,311 \\
13,037 \\
2,623 \\
840 \\
1,512\end{array}$ & $\begin{array}{r}12 \\
1 \\
1 \\
- \\
5 \\
5 \\
- \\
-\end{array}$ & $\begin{array}{r}20 \\
4 \\
2 \\
5 \\
3 \\
2 \\
0 \\
2\end{array}$ & $\begin{array}{r}59 \\
13 \\
6 \\
31 \\
12 \\
9 \\
18 \\
10\end{array}$ & $\begin{array}{r}402 \\
90 \\
47 \\
97 \\
77 \\
53 \\
11 \\
27\end{array}$ & $\begin{array}{r}375 \\
88 \\
41 \\
77 \\
71 \\
41 \\
6 \\
51\end{array}$ \\
\hline $\begin{array}{l}\text { S. Atlantic } \\
\text { Delaware } \\
\text { District of Columbia } \\
\text { Florida } \\
\text { Georgia } \\
\text { Maryland }^{\dagger} \\
\text { North Carolina }^{\dagger} \text { South Carolina }^{\dagger} \\
\text { Virginia }^{\dagger} \\
\text { West Virginia }^{-1}\end{array}$ & $\begin{array}{r}2,507 \\
115 \\
- \\
557 \\
5 \\
564 \\
- \\
679 \\
526 \\
61\end{array}$ & $\begin{array}{r}3,791 \\
87 \\
108 \\
1,405 \\
368 \\
452 \\
523 \\
522 \\
592 \\
67\end{array}$ & $\begin{array}{r}5,681 \\
156 \\
178 \\
1,669 \\
1,323 \\
1,031 \\
908 \\
729 \\
924 \\
137\end{array}$ & $\begin{array}{r}87,283 \\
2,169 \\
2,291 \\
36,005 \\
4,902 \\
11,169 \\
13,750 \\
15,209 \\
1,788\end{array}$ & $\begin{array}{r}129,320 \\
2,417 \\
3,623 \\
37,317 \\
20,841 \\
11,089 \\
22,147 \\
14,171 \\
15,773 \\
1,942\end{array}$ & $\begin{array}{l}\frac{17}{-} \\
\overline{12} \\
3 \\
- \\
- \\
1 \\
-\end{array}$ & $\begin{array}{r}18 \\
0 \\
0 \\
8 \\
6 \\
1 \\
1 \\
1 \\
2 \\
0\end{array}$ & $\begin{array}{r}50 \\
2 \\
1 \\
24 \\
31 \\
3 \\
31 \\
11 \\
7 \\
7 \\
2\end{array}$ & $\begin{array}{r}433 \\
2 \\
2 \\
179 \\
152 \\
13 \\
11 \\
24 \\
44 \\
6\end{array}$ & $\begin{array}{r}439 \\
1 \\
4 \\
139 \\
179 \\
22 \\
38 \\
23 \\
28 \\
5\end{array}$ \\
\hline $\begin{array}{l}\text { E.S. Central } \\
\text { Alabama }^{\dagger} \\
\text { Kentucky } \\
\text { Mississippi } \\
\text { Tennessee }^{\dagger}\end{array}$ & $\begin{array}{r}1,296 \\
-467 \\
367 \\
462\end{array}$ & $\begin{array}{r}1,761 \\
473 \\
328 \\
424 \\
564\end{array}$ & $\begin{array}{r}2,321 \\
652 \\
642 \\
784 \\
734\end{array}$ & $\begin{array}{r}42,030 \\
11,515 \\
8,012 \\
9,142 \\
13,361\end{array}$ & $\begin{array}{r}46,568 \\
13,892 \\
5,677 \\
12,043 \\
14,956\end{array}$ & $\begin{array}{l}- \\
- \\
-\end{array}$ & $\begin{array}{l}4 \\
1 \\
1 \\
0 \\
1\end{array}$ & $\begin{array}{r}10 \\
5 \\
4 \\
3 \\
5\end{array}$ & $\begin{array}{r}86 \\
34 \\
26 \\
6 \\
20\end{array}$ & $\begin{array}{r}80 \\
27 \\
20 \\
6 \\
27\end{array}$ \\
\hline $\begin{array}{l}\text { W.S. Central } \\
\text { Arkansas } \\
\text { Louisiana } \\
\text { Oklahoma }^{+} \\
\text {Texas }^{\dagger}\end{array}$ & $\begin{array}{r}530 \\
304 \\
-226 \\
-\end{array}$ & $\begin{array}{r}2,907 \\
232 \\
311 \\
261 \\
2,065\end{array}$ & $\begin{array}{r}4,578 \\
402 \\
1,055 \\
1,564 \\
3,213\end{array}$ & $\begin{array}{r}71,605 \\
4,127 \\
2,922 \\
7,469 \\
57,087\end{array}$ & $\begin{array}{r}82,455 \\
7,276 \\
15,145 \\
6,598 \\
53,436\end{array}$ & $\begin{array}{c}4 \\
- \\
3 \\
1\end{array}$ & $\begin{array}{l}8 \\
1 \\
1 \\
2 \\
5\end{array}$ & $\begin{array}{r}40 \\
5 \\
6 \\
9 \\
30\end{array}$ & $\begin{array}{r}144 \\
17 \\
17 \\
32 \\
78\end{array}$ & $\begin{array}{r}148 \\
15 \\
16 \\
35 \\
82\end{array}$ \\
\hline $\begin{array}{l}\text { Mountain } \\
\text { Arizona } \\
\text { Colorado } \\
\text { Idaho }^{\dagger} \\
\text { Montana }^{\dagger} \\
\text { Nevada }^{\dagger} \\
\text { New Mexico } \\
\text { Utah } \\
\text { Wyoming } \\
\text { Wy }\end{array}$ & $\begin{array}{r}\frac{512}{318} \\
\frac{22}{133} \\
\frac{139}{-}\end{array}$ & $\begin{array}{r}1,522 \\
471 \\
400 \\
66 \\
58 \\
177 \\
163 \\
117 \\
36\end{array}$ & $\begin{array}{r}2,118 \\
713 \\
709 \\
192 \\
77 \\
478 \\
453 \\
175 \\
70\end{array}$ & $\begin{array}{r}34,277 \\
9,605 \\
9,463 \\
1,522 \\
1,498 \\
4,928 \\
3,304 \\
3,062 \\
895\end{array}$ & \begin{tabular}{r|}
36,376 \\
12,859 \\
6,839 \\
1,780 \\
1,549 \\
4,974 \\
4,229 \\
3,168 \\
978
\end{tabular} & $\begin{array}{r}\frac{7}{3} \\
2 \\
-1 \\
-1 \\
-\end{array}$ & $\begin{array}{l}9 \\
0 \\
2 \\
2 \\
1 \\
0 \\
2 \\
1 \\
0\end{array}$ & $\begin{array}{r}25 \\
3 \\
10 \\
7 \\
4 \\
2 \\
8 \\
4 \\
2\end{array}$ & $\begin{array}{r}207 \\
14 \\
57 \\
40 \\
26 \\
7 \\
31 \\
24 \\
8\end{array}$ & $\begin{array}{r}213 \\
20 \\
57 \\
26 \\
17 \\
7 \\
61 \\
11 \\
14\end{array}$ \\
\hline $\begin{array}{l}\text { Pacific } \\
\text { Alaska } \\
\text { California } \\
\text { Hawaii } \\
\text { Oregon } \\
\text { Washington }\end{array}$ & $\begin{array}{r}960 \\
712 \\
\overline{-} \\
248\end{array}$ & $\begin{array}{r}3,467 \\
105 \\
2,713 \\
113 \\
162 \\
391\end{array}$ & $\begin{array}{r}5,350 \\
146 \\
4,406 \\
159 \\
468 \\
638\end{array}$ & $\begin{array}{r}83,101 \\
2,828 \\
66,684 \\
2,646 \\
1,367 \\
9,576\end{array}$ & $\begin{array}{r}96,236 \\
2,652 \\
73,868 \\
3,116 \\
5,487 \\
11,113\end{array}$ & $\begin{array}{r}\frac{9}{3} \\
\frac{3}{4} \\
2\end{array}$ & $\begin{array}{r}12 \\
0 \\
8 \\
0 \\
2 \\
1\end{array}$ & $\begin{array}{r}27 \\
1 \\
20 \\
0 \\
10 \\
8\end{array}$ & $\begin{array}{r}255 \\
2 \\
151 \\
64 \\
38\end{array}$ & $\begin{array}{r}298 \\
2 \\
163 \\
1 \\
94 \\
38\end{array}$ \\
\hline $\begin{array}{l}\text { American Samoa } \\
\text { C.N.M.I. } \\
\text { Guam } \\
\text { Puerto Rico }\end{array}$ & $\begin{array}{l}- \\
\bar{z}\end{array}$ & $\begin{array}{r}0 \\
4 \\
99\end{array}$ & $\begin{array}{r}\frac{0}{27} \\
329\end{array}$ & $\begin{array}{r}\overline{-} \\
88 \\
2,469\end{array}$ & $\begin{array}{r}-\overline{-} \\
221 \\
4,021\end{array}$ & $\frac{\mathrm{N}}{\bar{N}}$ & $\frac{0}{0}$ & $\begin{array}{l}\frac{0}{0} \\
0\end{array}$ & $\frac{N}{\bar{N}}$ & $\frac{N}{N}$ \\
\hline U.S. Virgin Islands & - & 8 & 15 & 132 & 288 & - & 0 & 0 & - & - \\
\hline
\end{tabular}

C.N.M.I.: Commonwealth of Northern Mariana Islands.

U: Unavailable. - - No reported cases. N: Not reportable. NN: Not Nationally Notifiable. Cum: Cumulative year-to-date counts. Med: Median. Max: Maximum.

* Incidence data for reporting years 2009 and 2010 are provisional. Data for HIV/AIDS, AIDS, and TB, when available, are displayed in Table IV, which appears quarterly.

† Contains data reported through the National Electronic Disease Surveillance System (NEDSS). 
TABLE II. (Continued) Provisional cases of selected notifiable diseases, United States, weeks ending July 3, 2010, and July 4, 2009 (26th week)*

\begin{tabular}{|c|c|c|c|c|c|c|c|c|c|c|}
\hline \multirow[b]{4}{*}{ Reporting area } & \multicolumn{10}{|c|}{ Dengue Virus Infection } \\
\hline & \multicolumn{5}{|c|}{ Dengue Fever ${ }^{\dagger}$} & \multicolumn{5}{|c|}{ Dengue Hemorrhagic Fever ${ }^{\S}$} \\
\hline & \multirow{2}{*}{$\begin{array}{c}\text { Current } \\
\text { week }\end{array}$} & \multicolumn{2}{|c|}{ Previous 52 weeks } & \multirow{2}{*}{$\begin{array}{l}\text { Cum } \\
2010 \\
\end{array}$} & \multirow{2}{*}{$\begin{array}{l}\text { Cum } \\
2009 \\
\end{array}$} & & Previou & weeks & Cum & Cum \\
\hline & & Med & Max & & & week & Med & Max & 2010 & 2009 \\
\hline United States & - & 0 & 8 & 69 & NN & - & 0 & 1 & 1 & NN \\
\hline New England & - & 0 & 1 & 1 & NN & - & 0 & 0 & - & NN \\
\hline Connecticut & - & 0 & 0 & - & NN & - & 0 & 0 & - & NN \\
\hline Maineף & - & 0 & 1 & 1 & NN & - & 0 & 0 & - & NN \\
\hline Massachusetts & - & 0 & 0 & - & NN & - & 0 & 0 & - & NN \\
\hline New Hampshire & - & 0 & 0 & - & NN & - & 0 & 0 & - & NN \\
\hline Rhode Island" & - & 0 & 0 & - & NN & - & 0 & 0 & - & NN \\
\hline Vermont ${ }^{\natural}$ & - & 0 & 0 & - & NN & - & 0 & 0 & - & NN \\
\hline Mid. Atlantic & - & 0 & 4 & 24 & NN & - & 0 & 0 & - & NN \\
\hline New Jersey & - & 0 & 0 & - & NN & - & 0 & 0 & - & NN \\
\hline New York (Upstate) & - & 0 & 0 & - & NN & - & 0 & 0 & - & NN \\
\hline New York City & - & 0 & 4 & 20 & NN & - & 0 & 0 & - & NN \\
\hline Pennsylvania & - & 0 & 2 & 4 & NN & - & 0 & 0 & - & NN \\
\hline E.N. Central & - & 0 & 2 & 5 & $\mathrm{NN}$ & - & 0 & 0 & - & NN \\
\hline Illinois & - & 0 & 0 & - & NN & - & 0 & 0 & - & NN \\
\hline Indiana & - & 0 & 0 & - & NN & - & 0 & 0 & - & NN \\
\hline Michigan & - & 0 & 0 & - & NN & - & 0 & 0 & - & NN \\
\hline Ohio & - & 0 & 2 & 5 & NN & - & 0 & 0 & - & NN \\
\hline Wisconsin & - & 0 & 0 & - & NN & - & 0 & 0 & - & NN \\
\hline W.N. Central & - & 0 & 0 & - & $\mathrm{NN}$ & - & 0 & 0 & - & $\mathrm{NN}$ \\
\hline lowa & - & 0 & 0 & - & NN & - & 0 & 0 & - & NN \\
\hline Kansas & - & 0 & 0 & - & NN & - & 0 & 0 & - & NN \\
\hline Minnesota & - & 0 & 0 & - & NN & - & 0 & 0 & - & NN \\
\hline Missouri & - & 0 & 0 & - & NN & - & 0 & 0 & - & NN \\
\hline Nebraska" & - & 0 & 0 & - & NN & - & 0 & 0 & - & NN \\
\hline North Dakota & - & 0 & 0 & - & NN & - & 0 & 0 & - & NN \\
\hline South Dakota & - & 0 & 0 & - & NN & - & 0 & 0 & - & NN \\
\hline S. Atlantic & - & 0 & 5 & 30 & NN & - & 0 & 1 & 1 & NN \\
\hline Delaware & - & 0 & 0 & - & NN & - & 0 & 0 & - & NN \\
\hline District of Columbia & - & 0 & 0 & - & NN & - & 0 & 0 & - & NN \\
\hline $\begin{array}{l}\text { Florida } \\
\text { andina }\end{array}$ & - & 0 & 5 & 25 & NN & - & 0 & 1 & 1 & NN \\
\hline Georgia & - & 0 & 2 & 3 & NN & - & 0 & 0 & - & NN \\
\hline Maryland & - & 0 & 0 & - & NN & - & 0 & 0 & - & NN \\
\hline North Carolina & - & 0 & 0 & - & NN & - & 0 & 0 & - & NN \\
\hline South Carolina" & - & 0 & 1 & 2 & NN & - & 0 & 0 & - & NN \\
\hline Virginia" & - & 0 & 0 & - & NN & - & 0 & 0 & - & NN \\
\hline West Virginia & - & 0 & 0 & - & NN & - & 0 & 0 & - & NN \\
\hline E.S.Central & - & 0 & 0 & - & NN & - & 0 & 0 & - & NN \\
\hline Alabama" & - & 0 & 0 & - & NN & - & 0 & 0 & - & NN \\
\hline Kentucky & - & 0 & 0 & - & NN & - & 0 & 0 & - & NN \\
\hline Mississippi & - & 0 & 0 & - & NN & - & 0 & 0 & - & NN \\
\hline Tennessee & - & 0 & 0 & - & NN & - & 0 & 0 & - & NN \\
\hline W.S.Central & - & 0 & 0 & - & $\mathrm{NN}$ & - & 0 & 0 & - & NN \\
\hline Arkansas" & - & 0 & 0 & - & NN & - & 0 & 0 & - & NN \\
\hline Louisiana & - & 0 & 0 & - & NN & - & 0 & 0 & - & NN \\
\hline Oklahoma & - & 0 & 0 & - & NN & - & 0 & 0 & - & NN \\
\hline Texas" & - & 0 & 0 & - & NN & - & 0 & 0 & - & NN \\
\hline Mountain & - & 0 & 1 & 2 & NN & - & 0 & 0 & - & NN \\
\hline Arizona & - & 0 & 0 & - & NN & - & 0 & 0 & - & NN \\
\hline Colorado & - & 0 & 0 & - & NN & - & 0 & 0 & - & NN \\
\hline Idahoף & - & 0 & 0 & - & NN & - & 0 & 0 & - & NN \\
\hline Montana" & - & 0 & 0 & - & NN & - & 0 & 0 & - & NN \\
\hline Nevada" & - & 0 & 1 & 1 & NN & - & 0 & 0 & - & NN \\
\hline New Mexico" & - & 0 & 1 & 1 & NN & - & 0 & 0 & - & NN \\
\hline Utah & - & 0 & 0 & - & NN & - & 0 & 0 & - & NN \\
\hline Wyoming? & - & 0 & 0 & - & NN & - & 0 & 0 & - & NN \\
\hline Pacific & - & 0 & 2 & & NN & - & 0 & 0 & - & NN \\
\hline Alaska & - & 0 & 0 & - & NN & - & 0 & 0 & - & NN \\
\hline California & - & 0 & 1 & 4 & $\mathrm{NN}$ & - & 0 & 0 & - & $\mathrm{NN}$ \\
\hline Hawaii & - & 0 & 0 & - & NN & - & 0 & 0 & - & NN \\
\hline Oregon & - & 0 & 0 & - & NN & - & 0 & 0 & - & NN \\
\hline Washington & - & 0 & 2 & 3 & NN & - & 0 & 0 & - & NN \\
\hline American Samoa & - & 0 & 0 & - & $\mathrm{NN}$ & - & 0 & 0 & - & $\mathrm{NN}$ \\
\hline C.N.M.I. & - & - & - & - & NN & - & - & - & - & NN \\
\hline Guam & - & 0 & 0 & - & NN & - & 0 & 0 & - & NN \\
\hline Puerto Rico & - & 0 & 82 & 942 & NN & - & 0 & 3 & 22 & NN \\
\hline U.S. Virgin Islands & - & 0 & 0 & - & NN & - & 0 & 0 & - & NN \\
\hline
\end{tabular}

C.N.M.I.: Commonwealth of Northern Mariana Islands.

U: Unavailable. - - No reported cases. N: Not reportable. NN: Not Nationally Notifiable. Cum: Cumulative year-to-date counts. Med: Median. Max: Maximum.

* Incidence data for reporting years 2009 and 2010 are provisional.

† Dengue Fever includes cases that meet criteria for Dengue Fever with hemorrhage.

$\S$ DHF includes cases that meet criteria for dengue shock syndrome (DSS), a more severe form of DHF.

१ Contains data reported through the National Electronic Disease Surveillance System (NEDSS). 
TABLE II. (Continued) Provisional cases of selected notifiable diseases, United States, weeks ending July 3, 2010, and July 4, 2009 (26th week)*

\begin{tabular}{|c|c|c|c|c|c|c|c|c|c|c|c|c|c|c|c|}
\hline \multirow[b]{4}{*}{ Reporting area } & \multicolumn{15}{|c|}{ Ehrlichiosis/Anaplasmosis ${ }^{\dagger}$} \\
\hline & \multicolumn{5}{|c|}{ Ehrlichia chaffeensis } & \multicolumn{5}{|c|}{ Anaplasma phagocytophilum } & \multicolumn{5}{|c|}{ Undetermined } \\
\hline & \multirow{2}{*}{$\begin{array}{l}\text { Current } \\
\text { week }\end{array}$} & Previous & 2 weeks & Cum & Cum & Current & Previous & 2 weeks & Cum & Cum & Current & Previous & weeks & Cum & Cum \\
\hline & & Med & Max & 2010 & 2009 & week & Med & Max & 2010 & 2009 & week & Med & Max & 2010 & 2009 \\
\hline United States & 7 & 9 & 176 & 158 & 316 & 11 & 13 & 309 & 134 & 350 & 1 & 1 & 35 & 19 & 74 \\
\hline New England & - & 0 & 6 & 4 & 18 & - & 2 & 22 & 16 & 107 & - & 0 & 1 & 2 & 2 \\
\hline Connecticut & - & 0 & 0 & - & - & - & 0 & 13 & - & 1 & - & 0 & 0 & - & - \\
\hline Maine ${ }^{\S}$ & - & 0 & 1 & 3 & 2 & - & 0 & 2 & 7 & 10 & - & 0 & 0 & - & - \\
\hline Massachusetts & - & 0 & 3 & - & 5 & - & 0 & 11 & - & 64 & - & 0 & 0 & - & - \\
\hline New Hampshire & - & 0 & 1 & 1 & 3 & - & 0 & 3 & 6 & 12 & - & 0 & 1 & 2 & 1 \\
\hline Rhode Island ${ }^{\S}$ & - & 0 & 4 & - & 8 & - & 0 & 20 & 3 & 20 & - & 0 & 0 & - & 1 \\
\hline Vermont ${ }^{\S}$ & - & 0 & 1 & - & - & - & 0 & 0 & - & - & - & 0 & 0 & - & - \\
\hline Mid. Atlantic & - & 1 & 15 & 13 & 62 & 10 & 3 & 27 & 52 & 98 & - & 0 & 4 & 1 & 20 \\
\hline New Jersey & - & 0 & 8 & - & 40 & - & 0 & 6 & 1 & 39 & - & 0 & 0 & - & - \\
\hline New York (Upstate) & - & 1 & 15 & 8 & 12 & 10 & 2 & 20 & 51 & 55 & - & 0 & 2 & 1 & 1 \\
\hline New York City & - & 0 & 2 & 4 & 4 & - & 0 & 1 & - & 3 & - & 0 & 0 & - & 1 \\
\hline Pennsylvania & - & 0 & 5 & 1 & 6 & - & 0 & 1 & - & 1 & - & 0 & 3 & - & 18 \\
\hline E.N. Central & - & 0 & 7 & 5 & 50 & 1 & 3 & 22 & 46 & 139 & - & 0 & 6 & 5 & 35 \\
\hline Illinois & - & 0 & 4 & 2 & 25 & - & 0 & 1 & - & 3 & - & 0 & 0 & - & 3 \\
\hline Indiana & - & 0 & 0 & - & - & - & 0 & 0 & - & - & - & 0 & 3 & 4 & 20 \\
\hline Michigan & - & 0 & 1 & - & 1 & - & 0 & 0 & - & - & - & 0 & 0 & - & - \\
\hline Ohio & - & 0 & 2 & - & 3 & - & 0 & 0 & - & 1 & - & 0 & 1 & - & - \\
\hline Wisconsin & - & 0 & 3 & 3 & 21 & 1 & 3 & 22 & 46 & 135 & - & 0 & 3 & 1 & 12 \\
\hline W.N. Central & 2 & 2 & 23 & 47 & 62 & - & 0 & 261 & 2 & - & 1 & 0 & 30 & 7 & 5 \\
\hline lowa & - & 0 & 0 & - & - & - & 0 & 0 & - & - & - & 0 & 0 & - & - \\
\hline Kansas & - & 0 & 1 & 2 & 4 & - & 0 & 1 & - & - & - & 0 & 0 & - & - \\
\hline Minnesota & - & 0 & 6 & - & - & - & 0 & 261 & - & - & - & 0 & 30 & - & 2 \\
\hline Missouri & 2 & 1 & 22 & 44 & 58 & - & 0 & 2 & 2 & - & 1 & 0 & 4 & 7 & 3 \\
\hline Nebraska ${ }^{\S}$ & - & 0 & 1 & 1 & - & - & 0 & 1 & - & - & - & 0 & 0 & - & - \\
\hline North Dakota & - & 0 & 0 & - & - & - & 0 & 0 & - & - & - & 0 & 0 & - & - \\
\hline South Dakota & - & 0 & 0 & - & - & - & 0 & 0 & - & - & - & 0 & 0 & - & - \\
\hline S. Atlantic & 4 & 3 & 14 & 56 & 64 & - & 0 & 4 & 16 & 4 & - & 0 & 2 & - & - \\
\hline Delaware & - & 0 & 3 & 9 & 8 & - & 0 & 1 & 2 & 1 & - & 0 & 0 & - & - \\
\hline District of Columbia & - & 0 & 0 & - & - & - & 0 & 0 & - & - & - & 0 & 0 & - & - \\
\hline Florida & 1 & 0 & 2 & 6 & 6 & - & 0 & 1 & 1 & - & - & 0 & 0 & - & - \\
\hline Georgia & - & 0 & 2 & 6 & 12 & - & 0 & 1 & 1 & 1 & - & 0 & 0 & - & - \\
\hline Maryland ${ }^{\S}$ & 1 & 0 & 3 & 8 & 23 & - & 0 & 2 & 7 & 2 & - & 0 & 0 & - & - \\
\hline North Carolina & - & 0 & 3 & 7 & - & - & 0 & 1 & 1 & - & - & 0 & 0 & - & - \\
\hline South Carolina ${ }^{\S}$ & - & 0 & 2 & 2 & 6 & - & 0 & 0 & - & - & - & 0 & 0 & - & - \\
\hline Virginia $\$$ & 2 & 1 & 13 & 18 & 9 & - & 0 & 2 & 4 & - & - & 0 & 2 & - & - \\
\hline West Virginia & - & 0 & 1 & - & - & - & 0 & 0 & - & - & - & 0 & 1 & - & - \\
\hline E.S.Central & 1 & 1 & 11 & 25 & 45 & - & 0 & 1 & 2 & 1 & - & 0 & 5 & 4 & 12 \\
\hline Alabamas & - & 0 & 3 & 4 & 1 & - & 0 & 1 & 1 & - & - & 0 & 0 & - & - \\
\hline Kentucky & - & 0 & 2 & 2 & 4 & - & 0 & 0 & - & - & - & 0 & 0 & - & - \\
\hline Mississippi & - & 0 & 2 & - & 5 & - & 0 & 0 & - & - & - & 0 & 0 & - & - \\
\hline Tennessee $^{\S}$ & 1 & 1 & 10 & 19 & 35 & - & 0 & 1 & 1 & 1 & - & 0 & 5 & 4 & 12 \\
\hline W.S.Central & - & 0 & 141 & 8 & 13 & - & 0 & 23 & - & 1 & - & 0 & 1 & - & - \\
\hline Arkansas§ & - & 0 & 34 & - & 2 & - & 0 & 6 & - & - & - & 0 & 0 & - & - \\
\hline Louisiana & - & 0 & 0 & - & - & - & 0 & 0 & - & - & - & 0 & 0 & - & - \\
\hline Oklahoma & - & 0 & 105 & 7 & 11 & - & 0 & 16 & - & 1 & - & 0 & 0 & - & - \\
\hline Texas $^{\S}$ & - & 0 & 2 & 1 & - & - & 0 & 1 & - & - & - & 0 & 1 & - & - \\
\hline Mountain & - & 0 & 0 & - & - & - & 0 & 0 & - & - & - & 0 & 1 & - & - \\
\hline Arizona & - & 0 & 0 & - & - & - & 0 & 0 & - & - & - & 0 & 1 & - & - \\
\hline Colorado & - & 0 & 0 & - & - & - & 0 & 0 & - & - & - & 0 & 0 & - & - \\
\hline Idaho ${ }^{\S}$ & - & 0 & 0 & - & - & - & 0 & 0 & - & - & - & 0 & 0 & - & - \\
\hline Montana ${ }^{\S}$ & - & 0 & 0 & - & - & - & 0 & 0 & - & - & - & 0 & 0 & - & - \\
\hline Nevadas & - & 0 & 0 & - & - & - & 0 & 0 & - & - & - & 0 & 0 & - & - \\
\hline New Mexico§ & - & 0 & 0 & - & - & - & 0 & 0 & - & - & - & 0 & 0 & - & - \\
\hline Utah & - & 0 & 0 & - & - & - & 0 & 0 & - & - & - & 0 & 0 & - & - \\
\hline Wyoming ${ }^{\S}$ & - & 0 & 0 & - & - & - & 0 & 0 & - & - & - & 0 & 0 & - & - \\
\hline Pacific & - & 0 & 1 & - & 2 & - & 0 & 1 & - & - & - & 0 & 1 & - & - \\
\hline Alaska & - & 0 & 0 & - & - & - & 0 & 0 & - & - & - & 0 & 0 & - & - \\
\hline California & - & 0 & 1 & - & 2 & - & 0 & 1 & - & - & - & 0 & 1 & - & - \\
\hline Hawaii & - & 0 & 0 & - & - & - & 0 & 0 & - & - & - & 0 & 0 & - & - \\
\hline Oregon & - & 0 & 0 & - & - & - & 0 & 0 & - & - & - & 0 & 0 & - & - \\
\hline Washington & - & 0 & 0 & - & - & - & 0 & 0 & - & - & - & 0 & 0 & - & - \\
\hline American Samoa & - & 0 & 0 & - & - & - & 0 & 0 & - & - & - & 0 & 0 & - & - \\
\hline C.N.M.I. & - & - & - & - & - & - & - & - & - & - & - & - & - & - & - \\
\hline Guam & - & 0 & 0 & - & - & - & 0 & 0 & - & - & - & 0 & 0 & - & - \\
\hline Puerto Rico & - & 0 & 0 & - & - & - & 0 & 0 & - & - & - & 0 & 0 & - & - \\
\hline U.S. Virgin Islands & - & 0 & 0 & - & - & - & 0 & 0 & - & - & - & 0 & 0 & - & - \\
\hline
\end{tabular}

C.N.M.I.: Commonwealth of Northern Mariana Islands.

U: Unavailable. - - No reported cases. N: Not reportable. NN: Not Nationally Notifiable. Cum: Cumulative year-to-date counts. Med: Median. Max: Maximum.

* Incidence data for reporting years 2009 and 2010 are provisional.

+ Cumulative total $E$. ewingii cases reported for year $2010=2$.

$\S$ Contains data reported through the National Electronic Disease Surveillance System (NEDSS). 
TABLE II. (Continued) Provisional cases of selected notifiable diseases, United States, weeks ending July 3, 2010, and July 4, 2009 (26th week)*

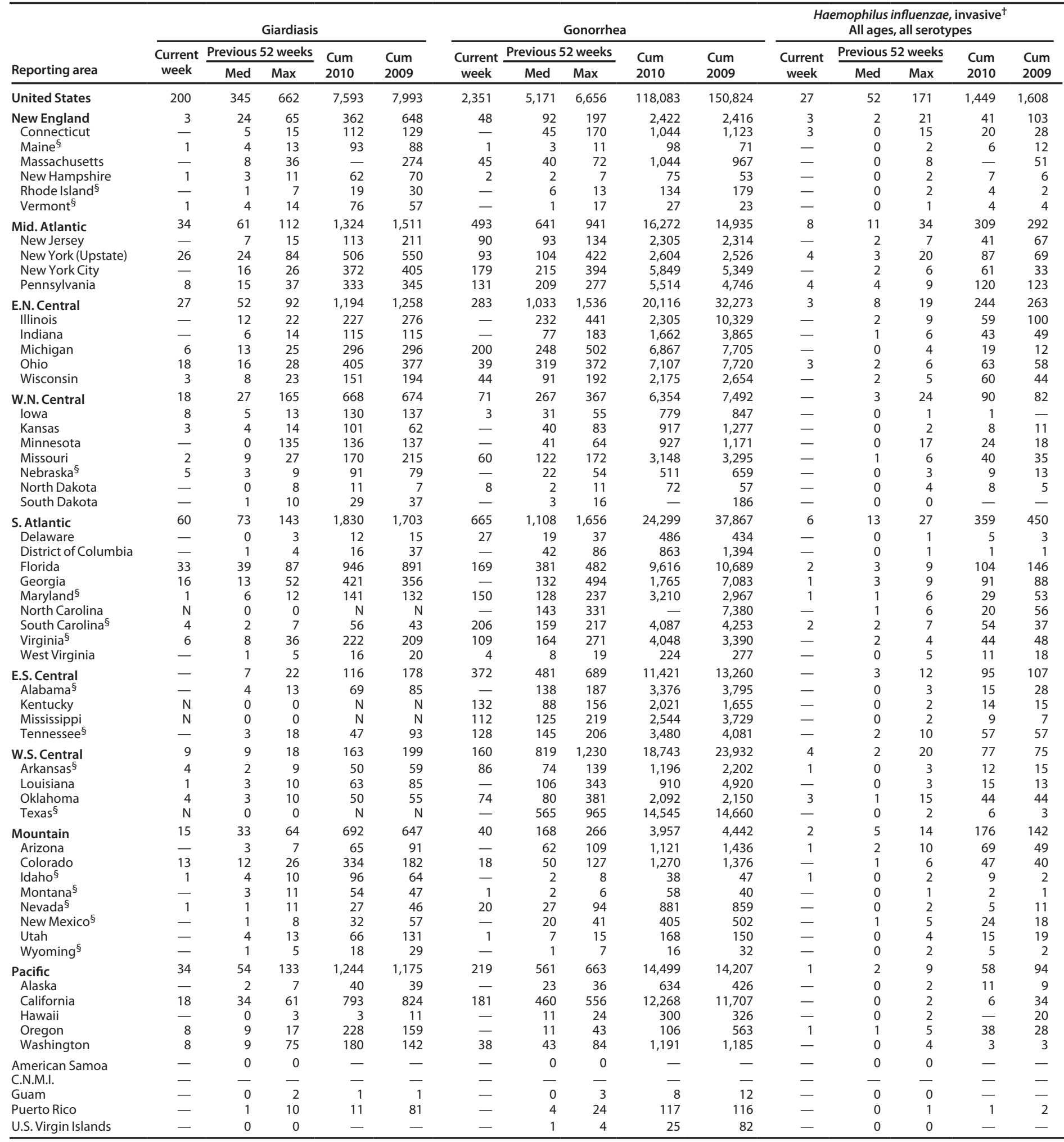

C.N.M.I.: Commonwealth of Northern Mariana Islands.

U: Unavailable. - - No reported cases. N: Not reportable. NN: Not Nationally Notifiable. Cum: Cumulative year-to-date counts. Med: Median. Max: Maximum.

* Incidence data for reporting years 2009 and 2010 are provisional.

† Data for $H$. influenzae (age $<5$ yrs for serotype $b$, nonserotype $b$, and unknown serotype) are available in Table I.

$\S$ Contains data reported through the National Electronic Disease Surveillance System (NEDSS). 


\begin{tabular}{|c|c|c|c|c|c|c|c|c|c|c|c|c|c|c|c|}
\hline \multirow[b]{4}{*}{ Reporting area } & \multicolumn{15}{|c|}{ Hepatitis (viral, acute), by type } \\
\hline & \multicolumn{5}{|c|}{ A } & \multicolumn{5}{|c|}{ B } & \multicolumn{5}{|c|}{ C } \\
\hline & \multirow{2}{*}{$\begin{array}{l}\text { Current } \\
\text { week }\end{array}$} & Previous & 2 weeks & Cum & & & Previous & 2 weeks & Cum & Cum & Current & Previous & 2 weeks & Cum & Cum \\
\hline & & Med & Max & 2010 & 2009 & week & Med & $\operatorname{Max}$ & 2010 & 2009 & week & Med & Max & 2010 & 2009 \\
\hline United States & 14 & 30 & 68 & 649 & 974 & 30 & 58 & 203 & 1,362 & 1,657 & 9 & 14 & 43 & 364 & 389 \\
\hline New England & 1 & 1 & 5 & 22 & 52 & - & 1 & 3 & 22 & 29 & - & 1 & 5 & 11 & 31 \\
\hline Connecticut & 1 & 0 & 2 & 14 & 12 & - & 0 & 2 & 6 & 8 & - & 1 & 4 & 11 & 23 \\
\hline Maine $^{\dagger}$ & - & 0 & 1 & 4 & 1 & - & 0 & 2 & 9 & 6 & - & 0 & 1 & - & - \\
\hline Massachusetts & - & 0 & 4 & - & 29 & - & 0 & 2 & - & 12 & - & 0 & 1 & - & 7 \\
\hline New Hampshire & - & 0 & 1 & - & 5 & - & 0 & 2 & 5 & 3 & - & 0 & 0 & - & - \\
\hline Rhode Island $^{\dagger}$ & - & 0 & 4 & 4 & 3 & - & 0 & 0 & - & U & - & 0 & 0 & - & u \\
\hline Vermont $^{\dagger}$ & - & 0 & 0 & - & 2 & - & 0 & 1 & 2 & - & - & 0 & 0 & - & 1 \\
\hline Mid. Atlantic & 2 & 4 & 10 & 92 & 139 & 2 & 5 & 10 & 140 & 196 & 2 & 2 & 5 & 53 & 48 \\
\hline New Jersey & - & 0 & 4 & 10 & 39 & - & 1 & 4 & 32 & 63 & - & 0 & 2 & 5 & 2 \\
\hline New York (Upstate) & - & 1 & 3 & 26 & 25 & 2 & 1 & 6 & 27 & 34 & 1 & 1 & 3 & 30 & 25 \\
\hline New York City & - & 1 & 5 & 29 & 40 & - & 1 & 4 & 43 & 34 & - & 0 & 1 & - & 1 \\
\hline Pennsylvania & 2 & 1 & 6 & 27 & 35 & - & 1 & 5 & 38 & 65 & 1 & 0 & 3 & 18 & 20 \\
\hline E.N. Central & 2 & 4 & 19 & 88 & 151 & 2 & 8 & 15 & 208 & 237 & - & 2 & 6 & 75 & 51 \\
\hline Illinois & - & 1 & 13 & 16 & 62 & - & 2 & 6 & 39 & 55 & - & 0 & 1 & 1 & 3 \\
\hline Indiana & - & 0 & 4 & 8 & 13 & - & 1 & 5 & 25 & 40 & - & 0 & 2 & 12 & 10 \\
\hline Michigan & - & 1 & 4 & 27 & 36 & 1 & 2 & 6 & 55 & 71 & - & 1 & 6 & 55 & 16 \\
\hline Ohio & 2 & 0 & 4 & 17 & 24 & 1 & 2 & 6 & 61 & 59 & - & 0 & 3 & 5 & 19 \\
\hline Wisconsin & - & 0 & 3 & 20 & 16 & - & 1 & 3 & 28 & 12 & - & 0 & 1 & 2 & 3 \\
\hline W.N.Central & - & 1 & 10 & 24 & 57 & 1 & 3 & 15 & 66 & 63 & - & 0 & 11 & 12 & 6 \\
\hline lowa & - & 0 & 3 & 4 & 17 & - & 1 & 3 & 10 & 15 & - & 0 & 4 & 1 & 3 \\
\hline Kansas & - & 0 & 2 & 7 & 6 & - & 0 & 2 & 4 & 4 & - & 0 & 0 & - & 1 \\
\hline Minnesota & - & 0 & 8 & 1 & 12 & - & 0 & 13 & 2 & 10 & - & 0 & 9 & 3 & - \\
\hline Missouri & - & 0 & 3 & 11 & 10 & 1 & 1 & 5 & 41 & 23 & - & 0 & 1 & 7 & - \\
\hline Nebraska $^{\dagger}$ & - & 0 & 3 & 1 & 10 & - & 0 & 2 & 9 & 10 & - & 0 & 1 & 1 & 2 \\
\hline North Dakota & - & 0 & 1 & - & - & - & 0 & 0 & - & - & - & 0 & 1 & - & - \\
\hline South Dakota & - & 0 & 1 & - & 2 & - & 0 & 1 & - & 1 & - & 0 & 1 & - & - \\
\hline S. Atlantic & 5 & 7 & 14 & 146 & 214 & 11 & 16 & 39 & 390 & 446 & 3 & 3 & 7 & 69 & 100 \\
\hline Delaware & - & 0 & 1 & 5 & 3 & - & 1 & 2 & 16 & 18 & u & 0 & 0 & u & u \\
\hline District of Columbia & - & 0 & 1 & 1 & 1 & - & 0 & 2 & 2 & 7 & - & 0 & 1 & 2 & - \\
\hline $\begin{array}{l}\text { Florida } \\
\text { andia }\end{array}$ & 3 & 3 & 8 & 61 & 96 & 5 & 5 & 11 & 153 & 156 & 1 & 1 & 4 & 25 & 20 \\
\hline Georgia & - & 1 & 3 & 17 & 23 & 3 & 3 & 7 & 78 & 71 & - & 0 & 2 & 6 & 24 \\
\hline Maryland ${ }^{\dagger}$ & - & 0 & 4 & 11 & 21 & 1 & 1 & 6 & 28 & 44 & 1 & 0 & 2 & 13 & 12 \\
\hline North Carolina & - & 0 & 3 & 11 & 33 & - & 0 & 4 & 4 & 63 & - & 0 & 4 & 9 & 20 \\
\hline South Carolina $^{\dagger}$ & - & 1 & 4 & 21 & 21 & 1 & 1 & 4 & 27 & 23 & - & 0 & 0 & - & 1 \\
\hline Virginia $^{+}$ & 2 & 1 & 3 & 18 & 16 & 1 & 2 & 14 & 50 & 41 & 1 & 0 & 2 & 8 & 7 \\
\hline West Virginia & - & 0 & 2 & 1 & - & - & 0 & 19 & 32 & 23 & - & 0 & 3 & 6 & 16 \\
\hline E.S. Central & - & 1 & 3 & 18 & 23 & 2 & 6 & 13 & 142 & 168 & 1 & 2 & 7 & 63 & 54 \\
\hline Alabama $^{\dagger}$ & - & 0 & 1 & 4 & 6 & - & 1 & 5 & 29 & 49 & - & 0 & 2 & 2 & 5 \\
\hline Kentucky & - & 0 & 2 & 9 & 4 & - & 2 & 6 & 45 & 42 & - & 1 & 5 & 43 & 33 \\
\hline Mississippi & - & 0 & 1 & - & 6 & - & 0 & 3 & 14 & 12 & - & 0 & 0 & - & u \\
\hline Tennessee $^{\dagger}$ & - & 0 & 2 & 5 & 7 & 2 & 2 & 6 & 54 & 65 & 1 & 0 & 4 & 18 & 16 \\
\hline W.S. Central & 1 & 3 & 19 & 71 & 91 & 8 & 9 & 109 & 201 & 280 & 1 & 1 & 14 & 27 & 25 \\
\hline Arkansas $^{\dagger}$ & - & 0 & 3 & - & 5 & - & 1 & 4 & 25 & 37 & - & 0 & 1 & - & 1 \\
\hline Louisiana & - & 0 & 2 & 6 & 2 & - & 1 & 5 & 20 & 31 & - & 0 & 1 & 3 & 4 \\
\hline Oklahoma & - & 0 & 3 & - & 1 & 5 & 1 & 19 & 35 & 50 & - & 0 & 12 & 13 & 4 \\
\hline Texas $^{\dagger}$ & 1 & 2 & 18 & 65 & 83 & 3 & 5 & 87 & 121 & 162 & 1 & 0 & 4 & 11 & 16 \\
\hline Mountain & - & 3 & 8 & 76 & 73 & - & 2 & 6 & 52 & 74 & - & 1 & 4 & 21 & 30 \\
\hline Arizona & - & 1 & 5 & 39 & 31 & - & 0 & 2 & 18 & 29 & - & 0 & 0 & - & U \\
\hline Colorado & - & 1 & 4 & 12 & 21 & - & 0 & 2 & 2 & 13 & - & 0 & 2 & 2 & 18 \\
\hline Idaho $^{\dagger}$ & - & 0 & 2 & 5 & 1 & - & 0 & 2 & 4 & 4 & - & 0 & 2 & 7 & 2 \\
\hline Montana ${ }^{\dagger}$ & - & 0 & 1 & 4 & 4 & - & 0 & 1 & 1 & - & - & 0 & 0 & - & 1 \\
\hline Nevada ${ }^{\dagger}$ & - & 0 & 2 & 6 & 7 & - & 0 & 3 & 21 & 15 & - & 0 & 1 & 2 & 2 \\
\hline New Mexico ${ }^{\dagger}$ & - & 0 & 1 & 3 & 6 & - & 0 & 1 & 2 & 5 & - & 0 & 2 & 6 & 5 \\
\hline Utah & - & 0 & 2 & 4 & 3 & - & 0 & 1 & 4 & 4 & - & 0 & 1 & 4 & 2 \\
\hline Wyoming $^{\dagger}$ & - & 0 & 3 & 3 & - & - & 0 & 1 & - & 4 & - & 0 & 0 & - & - \\
\hline Pacific & 3 & 5 & 16 & 112 & 174 & 4 & 6 & 20 & 141 & 164 & 2 & 1 & 6 & 33 & 44 \\
\hline Alaska & - & 0 & 0 & - & 2 & - & 0 & 1 & 1 & 2 & - & 0 & 2 & - & U \\
\hline California & 3 & 4 & 15 & 90 & 130 & 1 & 4 & 16 & 97 & 117 & 1 & 0 & 4 & 14 & 22 \\
\hline Hawaii & - & 0 & 2 & - & 7 & - & 0 & 1 & - & 4 & - & 0 & 0 & - & U \\
\hline Oregon & - & 0 & 2 & 11 & 9 & - & 1 & 4 & 23 & 23 & - & 0 & 3 & 8 & 11 \\
\hline Washington & - & 0 & 2 & 11 & 26 & 3 & 0 & 4 & 20 & 18 & 1 & 0 & 6 & 11 & 11 \\
\hline & - & 0 & 0 & - & - & - & 0 & 0 & - & - & - & 0 & 0 & - & - \\
\hline $\begin{array}{l}\text { C.N.M.I. } \\
\text { (1) }\end{array}$ & - & - & - & - & - & - & - & - & - & - & - & - & - & - & - \\
\hline Guam & - & 0 & 6 & 12 & 4 & - & 0 & 6 & 22 & 37 & - & 0 & 6 & 21 & 26 \\
\hline Puerto Rico & - & 0 & 2 & 2 & 18 & - & 0 & 5 & 8 & 19 & - & 0 & 0 & - & - \\
\hline U.S. Virgin Islands & - & 0 & 0 & - & - & - & 0 & 0 & - & - & - & 0 & 0 & - & - \\
\hline
\end{tabular}

C.N.M.I.: Commonwealth of Northern Mariana Islands.

U: Unavailable. - -: No reported cases. N: Not reportable. NN: Not Nationally Notifiable. Cum: Cumulative year-to-date counts. Med: Median. Max: Maximum.

* Incidence data for reporting years 2009 and 2010 are provisional.

† Contains data reported through the National Electronic Disease Surveillance System (NEDSS). 
TABLE II. (Continued) Provisional cases of selected notifiable diseases, United States, weeks ending July 3, 2010, and July 4, 2009 (26th week)*

\begin{tabular}{|c|c|c|c|c|c|c|c|c|c|c|c|c|c|c|c|}
\hline \multirow[b]{3}{*}{ Reporting area } & \multicolumn{5}{|c|}{ Legionellosis } & \multicolumn{5}{|c|}{ Lyme disease } & \multicolumn{5}{|c|}{ Malaria } \\
\hline & \multirow{2}{*}{$\begin{array}{c}\text { Current } \\
\text { week }\end{array}$} & \multicolumn{2}{|c|}{ Previous 52 weeks } & \multirow{2}{*}{$\begin{array}{l}\text { Cum } \\
2010\end{array}$} & & & Previous & 52 weeks & Cum & Cum & Current & Previous & 2 weeks & Cum & Cum \\
\hline & & Med & Max & & 2009 & week & Med & Max & 2010 & 2009 & week & Med & Max & 2010 & 2009 \\
\hline United States & 60 & 58 & 174 & 1,074 & 1,165 & 374 & 393 & 2,345 & 7,164 & 13,965 & 13 & 25 & 87 & 494 & 578 \\
\hline $\begin{array}{l}\text { New England } \\
\text { Connecticut }\end{array}$ & - & $\begin{array}{l}2 \\
1\end{array}$ & $\begin{array}{r}18 \\
4\end{array}$ & $\begin{array}{l}25 \\
12\end{array}$ & $\begin{array}{l}62 \\
19\end{array}$ & $\underline{40}$ & $\begin{array}{l}93 \\
37\end{array}$ & $\begin{array}{l}857 \\
295\end{array}$ & $\begin{array}{r}1,392 \\
687\end{array}$ & $\begin{array}{l}5,368 \\
1,964\end{array}$ & - & $\begin{array}{l}1 \\
0\end{array}$ & $\begin{array}{l}4 \\
1\end{array}$ & $\begin{array}{l}7 \\
1\end{array}$ & $\begin{array}{r}27 \\
4\end{array}$ \\
\hline Maine $^{\dagger}$ & - & 0 & $\begin{array}{l}4 \\
3\end{array}$ & 3 & - & $\overline{24}$ & 13 & 76 & 201 & $\begin{array}{r}1,504 \\
161\end{array}$ & - & 0 & 1 & 3 & 1 \\
\hline Massachusetts & - & 0 & 9 & - & 37 & - & 16 & 401 & - & 2,396 & - & 0 & 3 & - & 16 \\
\hline New Hampshire & - & 0 & 3 & 3 & 3 & 1 & 21 & 95 & 409 & 672 & - & 0 & 1 & 1 & 2 \\
\hline Rhode Island ${ }^{\dagger}$ & - & 0 & 4 & 5 & 2 & - & 1 & 29 & 10 & 56 & - & 0 & 1 & 1 & 2 \\
\hline Vermont $^{\dagger}$ & - & 0 & 1 & 2 & 1 & 15 & 4 & 45 & 85 & 119 & - & 0 & 1 & 1 & 2 \\
\hline Mid. Atlantic & 19 & 15 & 73 & 247 & 381 & 255 & 187 & 999 & 3,820 & 5,527 & - & 7 & 17 & 143 & 168 \\
\hline New Jersey & - & 1 & 14 & 4 & 87 & 5 & 43 & 430 & 933 & 2,462 & - & 0 & 5 & 1 & 46 \\
\hline New York (Upstate) & 12 & 5 & 29 & 89 & 87 & 129 & 56 & 577 & 943 & 1,092 & - & 1 & 4 & 33 & 24 \\
\hline New York City & - & 2 & 19 & 47 & 78 & - & 3 & 58 & 3 & 392 & - & 3 & 12 & 83 & 70 \\
\hline Pennsylvania & 7 & 6 & 23 & 107 & 129 & 121 & 72 & 475 & 1,941 & 1,581 & - & 1 & 4 & 26 & 28 \\
\hline E.N.Central & 14 & 11 & 41 & 217 & 208 & 3 & 23 & 258 & 510 & 1,201 & 1 & 2 & 12 & 52 & 73 \\
\hline Illinois & - & 1 & 11 & 8 & 29 & - & 1 & 12 & 13 & 60 & - & 1 & 7 & 19 & 34 \\
\hline Indiana & 1 & 1 & 6 & 39 & 25 & - & 1 & 6 & 20 & 33 & - & 0 & 4 & 7 & 9 \\
\hline Michigan & 2 & 2 & 13 & 38 & 40 & - & 1 & 9 & 20 & 16 & - & 0 & 3 & 6 & 11 \\
\hline Ohio & 11 & 5 & 17 & 108 & 86 & 1 & 1 & 5 & 9 & 10 & 1 & 0 & 6 & 19 & 15 \\
\hline Wisconsin & - & 1 & 6 & 24 & 28 & 2 & 18 & 239 & 448 & 1,082 & - & 0 & 2 & 1 & 4 \\
\hline W.N.Central & 2 & 2 & 19 & 51 & 43 & - & 2 & 1,395 & 27 & 106 & - & 1 & 11 & 24 & 27 \\
\hline lowa & - & 0 & 3 & 4 & 11 & - & 0 & 14 & 16 & 66 & - & 0 & 1 & 6 & 5 \\
\hline Kansas & - & 0 & 2 & 5 & 4 & - & 0 & 2 & 5 & 12 & - & 0 & 1 & 3 & 2 \\
\hline Minnesota & - & 0 & 16 & 15 & 5 & - & 0 & 1,380 & - & 26 & - & 0 & 11 & 3 & 12 \\
\hline Missouri & 2 & 1 & 5 & 18 & 17 & - & 0 & 1 & 3 & 1 & - & 0 & 1 & 4 & 5 \\
\hline Nebraska $^{\dagger}$ & - & 0 & 2 & 4 & 5 & - & 0 & 1 & 3 & - & - & 0 & 2 & 8 & 2 \\
\hline North Dakota & - & 0 & 1 & 3 & 1 & - & 0 & 15 & - & - & - & 0 & 1 & - & - \\
\hline South Dakota & - & 0 & 1 & 2 & - & - & 0 & 0 & - & 1 & - & 0 & 0 & - & 1 \\
\hline S. Atlantic & 13 & 11 & 24 & 227 & 224 & 75 & 62 & 258 & 1,244 & 1,621 & 10 & 6 & 15 & 134 & 166 \\
\hline Delaware & - & 0 & 5 & 8 & 8 & 11 & 12 & 65 & 297 & 393 & - & 0 & 1 & 2 & 1 \\
\hline District of Columbia & - & 0 & 4 & 12 & 13 & - & 0 & 4 & 8 & 32 & - & 0 & 3 & 6 & 6 \\
\hline Florida & 8 & 4 & 10 & 86 & 70 & 6 & 2 & 11 & 32 & 17 & 3 & 2 & 7 & 55 & 41 \\
\hline Georgia & - & 1 & 4 & 23 & 25 & - & 0 & 6 & 4 & 27 & - & 0 & 6 & 3 & 36 \\
\hline Maryland ${ }^{\dagger}$ & 5 & 3 & 12 & 52 & 56 & 40 & 27 & 134 & 569 & 793 & 2 & 1 & 13 & 28 & 42 \\
\hline North Carolina & - & 0 & 5 & 2 & 27 & - & 0 & 6 & 12 & 56 & - & 0 & 3 & 5 & 18 \\
\hline South Carolina ${ }^{\dagger}$ & - & 0 & 2 & 5 & 3 & - & 1 & 3 & 17 & 17 & - & 0 & 1 & 3 & 1 \\
\hline Virginia $^{\dagger}$ & - & 1 & 6 & 34 & 22 & 18 & 14 & 79 & 290 & 253 & 5 & 1 & 5 & 32 & 20 \\
\hline West Virginia & - & 0 & 3 & 5 & - & - & 0 & 33 & 15 & 33 & - & 0 & 2 & - & 1 \\
\hline E.S.Central & 3 & 2 & 12 & 58 & 55 & 1 & 1 & 4 & 22 & 11 & - & 0 & 4 & 11 & 20 \\
\hline Alabama $^{+}$ & - & 0 & 2 & 7 & 9 & - & 0 & 1 & - & 1 & - & 0 & 3 & 2 & 6 \\
\hline Kentucky & - & 0 & 3 & 10 & 23 & - & 0 & 1 & 1 & 1 & - & 0 & 3 & 3 & 5 \\
\hline Mississippi & - & 0 & 2 & 5 & 2 & - & 0 & 0 & - & - & - & 0 & 1 & - & 2 \\
\hline Tennessee $^{\dagger}$ & 3 & 1 & 9 & 36 & 21 & 1 & 1 & 4 & 21 & 9 & - & 0 & 1 & 6 & 7 \\
\hline W.S.Central & - & 2 & 14 & 41 & 52 & - & 3 & 44 & 31 & 51 & - & 1 & 31 & 47 & 20 \\
\hline Arkansas $^{\dagger}$ & - & 0 & 2 & 8 & 4 & - & 0 & 0 & - & - & - & 0 & 1 & 1 & 2 \\
\hline Louisiana & - & 0 & 3 & 1 & 5 & - & 0 & 0 & - & - & - & 0 & 1 & - & 4 \\
\hline Oklahoma & - & 0 & 4 & 6 & 3 & - & 0 & 2 & - & - & - & 0 & 1 & 3 & - \\
\hline Texas $^{\dagger}$ & - & 1 & 10 & 26 & 40 & - & 3 & 42 & 31 & 51 & - & 1 & 30 & 43 & 14 \\
\hline Mountain & 3 & 3 & 8 & 71 & 57 & - & 0 & 4 & 6 & 24 & - & 1 & 6 & 20 & 17 \\
\hline Arizona & 3 & 1 & 4 & 22 & 23 & - & 0 & 1 & 1 & 1 & - & 0 & 2 & 11 & 2 \\
\hline Colorado & - & 1 & 5 & 17 & 7 & - & 0 & 1 & 1 & - & - & 0 & 3 & 3 & 11 \\
\hline Idaho $^{\dagger}$ & - & 0 & 2 & - & 1 & - & 0 & 3 & 1 & 6 & - & 0 & 1 & - & 1 \\
\hline Montana $^{\dagger}$ & - & 0 & 1 & 4 & 4 & - & 0 & 1 & - & 1 & - & 0 & 3 & 1 & 1 \\
\hline Nevada ${ }^{\dagger}$ & - & 0 & 2 & 15 & 6 & - & 0 & 2 & - & 8 & - & 0 & 1 & 2 & - \\
\hline New Mexico ${ }^{\dagger}$ & - & 0 & 2 & 2 & 1 & - & 0 & 1 & 1 & 1 & - & 0 & 0 & - & - \\
\hline Utah & - & 0 & 3 & 9 & 14 & - & 0 & 1 & 2 & 6 & - & 0 & 1 & 3 & 2 \\
\hline Wyoming $^{\dagger}$ & - & 0 & 2 & 2 & 1 & - & 0 & 1 & - & 1 & - & 0 & 0 & - & - \\
\hline Pacific & 6 & 4 & 19 & 137 & 83 & - & 5 & 10 & 112 & 56 & 2 & 3 & 19 & 56 & 60 \\
\hline Alaska & - & 0 & 0 & - & 1 & - & 0 & 1 & 1 & 3 & - & 0 & 1 & 2 & 2 \\
\hline California & 3 & 3 & 19 & 119 & 63 & - & 3 & 9 & 75 & 31 & 1 & 1 & 13 & 34 & 45 \\
\hline Hawaii & - & 0 & 1 & 1 & 1 & $\mathrm{~N}$ & 0 & 0 & $\mathrm{~N}$ & $\mathrm{~N}$ & - & 0 & 0 & - & 1 \\
\hline Oregon & 1 & 0 & 3 & 6 & 7 & - & 1 & 4 & 32 & 19 & - & 0 & 1 & 5 & 7 \\
\hline Washington & 2 & 0 & 4 & 11 & 11 & - & 0 & 3 & 4 & 3 & 1 & 0 & 5 & 15 & 5 \\
\hline American Samoa & - & 0 & 0 & - & - & $\mathrm{N}$ & 0 & 0 & $\mathrm{~N}$ & $\mathrm{~N}$ & - & 0 & 0 & - & - \\
\hline C.N.M.I. & - & - & - & - & - & - & - & - & - & - & - & - & - & - & - \\
\hline Guam & - & 0 & 0 & - & - & - & 0 & 0 & - & - & - & 0 & 0 & - & - \\
\hline Puerto Rico & - & 0 & 1 & - & - & $\mathrm{N}$ & 0 & 0 & $\mathrm{~N}$ & $\mathrm{~N}$ & - & 0 & 2 & 1 & 1 \\
\hline U.S. Virgin Islands & - & 0 & 0 & - & - & - & 0 & 0 & - & - & - & 0 & 0 & - & - \\
\hline
\end{tabular}

C.N.M.I.: Commonwealth of Northern Mariana Islands.

U: Unavailable. - - No reported cases. N: Not reportable. NN: Not Nationally Notifiable. Cum: Cumulative year-to-date counts. Med: Median. Max: Maximum. * Incidence data for reporting years 2009 and 2010 are provisional.

† Contains data reported through the National Electronic Disease Surveillance System (NEDSS). 
TABLE II. (Continued) Provisional cases of selected notifiable diseases, United States, weeks ending July 3, 2010, and July 4, 2009 (26th week)*

\begin{tabular}{|c|c|c|c|c|c|c|c|c|c|c|c|c|c|c|c|}
\hline \multirow[b]{3}{*}{ Reporting area } & \multicolumn{5}{|c|}{$\begin{array}{l}\text { Meningococcal disease, invasive }{ }^{\dagger} \\
\text { All groups }\end{array}$} & \multicolumn{5}{|c|}{ Pertussis } & \multicolumn{5}{|c|}{ Rabies, animal } \\
\hline & \multirow{2}{*}{$\begin{array}{l}\text { Current } \\
\text { week }\end{array}$} & \multicolumn{2}{|c|}{ Previous 52 weeks } & & & & Previous & 52 weeks & & Cum & Current & Previous & weeks & Cum & Cum \\
\hline & & Med & $\operatorname{Max}$ & 2010 & 2009 & week & Med & $\operatorname{Max}$ & 2010 & 2009 & week & Med & $\operatorname{Max}$ & 2010 & 2009 \\
\hline United States & 9 & 16 & 43 & 406 & 550 & 136 & 273 & 1,750 & 5,999 & 6,986 & 31 & 66 & 147 & 1,320 & 2,581 \\
\hline New England & 1 & 0 & 2 & 7 & 18 & - & 5 & 21 & 46 & 347 & 2 & 5 & 24 & 118 & 169 \\
\hline Connecticut & 1 & 0 & 2 & 1 & 2 & - & 1 & 5 & 20 & 19 & - & 1 & 22 & 59 & 73 \\
\hline Maine ${ }^{\S}$ & - & 0 & 1 & 2 & 2 & - & 0 & 4 & 12 & 60 & - & 1 & 4 & 28 & 28 \\
\hline Massachusetts & - & 0 & 1 & - & 10 & - & 3 & 12 & - & 205 & - & 0 & 0 & - & - \\
\hline New Hampshire & - & 0 & 1 & - & 1 & - & 0 & 4 & 6 & 44 & - & 0 & 2 & 3 & 19 \\
\hline Rhode Island ${ }^{\S}$ & - & 0 & 1 & - & 2 & - & 0 & 8 & 5 & 11 & - & 0 & 5 & 3 & 20 \\
\hline Vermont $^{\S}$ & - & 0 & 1 & 4 & 1 & - & 0 & 1 & 3 & 8 & 2 & 1 & 5 & 25 & 29 \\
\hline Mid. Atlantic & 1 & 1 & 4 & 37 & 62 & 35 & 20 & 41 & 412 & 574 & 8 & 11 & 26 & 343 & 294 \\
\hline New Jersey & - & 0 & 2 & 8 & 11 & - & 3 & 10 & 46 & 127 & - & 0 & 0 & - & - \\
\hline New York (Upstate) & 1 & 0 & 3 & 9 & 12 & 27 & 6 & 27 & 174 & 91 & 8 & 9 & 22 & 239 & 192 \\
\hline New York City & - & 0 & 2 & 8 & 12 & - & 0 & 11 & 24 & 49 & - & 2 & 12 & 104 & 2 \\
\hline Pennsylvania & - & 0 & 2 & 12 & 27 & 8 & 8 & 22 & 168 & 307 & - & 0 & 0 & - & 100 \\
\hline E.N. Central & - & 2 & 8 & 68 & 103 & 36 & 61 & 108 & 1,483 & 1,410 & 5 & 2 & 19 & 79 & 83 \\
\hline Illinois & - & 0 & 4 & 11 & 26 & 1 & 11 & 29 & 241 & 335 & 3 & 1 & 9 & 33 & 27 \\
\hline Indiana & - & 0 & 3 & 15 & 23 & - & 7 & 19 & 150 & 163 & - & 0 & 5 & - & 17 \\
\hline Michigan & - & 0 & 2 & 10 & 17 & 8 & 19 & 41 & 426 & 294 & - & 1 & 6 & 27 & 24 \\
\hline Ohio & - & 1 & 2 & 18 & 23 & 26 & 18 & 46 & 579 & 535 & 2 & 0 & 5 & 19 & 15 \\
\hline Wisconsin & - & 0 & 2 & 14 & 14 & 1 & 3 & 12 & 87 & 83 & - & 0 & 0 & - & - \\
\hline W.N. Central & 1 & 2 & 6 & 32 & 40 & 6 & 25 & 627 & 440 & 1,085 & 7 & 6 & 18 & 124 & 191 \\
\hline lowa & - & 0 & 3 & 6 & 6 & - & 4 & 21 & 155 & 125 & - & 0 & 4 & 7 & 17 \\
\hline Kansas & - & 0 & 2 & 4 & 7 & - & 3 & 12 & 63 & 120 & 1 & 1 & 4 & 33 & 49 \\
\hline Minnesota & - & 0 & 2 & 2 & 8 & - & 0 & 601 & 6 & 194 & - & 1 & 9 & 15 & 20 \\
\hline Missouri & - & 0 & 3 & 14 & 13 & 1 & 11 & 35 & 146 & 545 & 3 & 1 & 5 & 33 & 20 \\
\hline Nebraska ${ }^{\S}$ & 1 & 0 & 2 & 5 & 4 & 5 & 2 & 6 & 51 & 88 & 3 & 1 & 6 & 29 & 52 \\
\hline North Dakota & - & 0 & 1 & 1 & - & - & 0 & 12 & 5 & 2 & - & 0 & 7 & 7 & 4 \\
\hline South Dakota & - & 0 & 2 & - & 2 & - & 1 & 6 & 14 & 11 & - & 0 & 4 & - & 29 \\
\hline S. Atlantic & 1 & 2 & 7 & 77 & 108 & 7 & 22 & 63 & 518 & 765 & 2 & 27 & 58 & 489 & 1,150 \\
\hline Delaware & - & 0 & 1 & 1 & 2 & - & 0 & 3 & 5 & 6 & - & 0 & 0 & - & - \\
\hline District of Columbia & - & 0 & 0 & - & - & - & 0 & 1 & 3 & 3 & - & 0 & 0 & - & - \\
\hline Florida & 1 & 1 & 5 & 39 & 32 & 5 & 6 & 28 & 137 & 252 & - & 0 & 22 & 52 & 161 \\
\hline Georgia & - & 0 & 1 & 6 & 20 & - & 3 & 8 & 87 & 134 & - & 4 & 14 & - & 217 \\
\hline Maryland ${ }^{\S}$ & - & 0 & 1 & 4 & 5 & 1 & 2 & 8 & 48 & 67 & - & 6 & 15 & 158 & 183 \\
\hline North Carolina & - & 0 & 2 & 5 & 27 & - & 0 & 6 & - & 110 & - & 3 & 17 & - & 253 \\
\hline South Carolina§ & - & 0 & 1 & 7 & 8 & 1 & 5 & 23 & 164 & 102 & - & 0 & 0 & - & - \\
\hline Virginias ${ }^{\S}$ & - & 0 & 2 & 13 & 10 & - & 4 & 15 & 65 & 85 & - & 10 & 26 & 240 & 277 \\
\hline West Virginia & - & 0 & 2 & 2 & 4 & - & 0 & 6 & 9 & 6 & 2 & 2 & 6 & 39 & 59 \\
\hline E.S. Central & - & 0 & 4 & 19 & 19 & 2 & 14 & 31 & 355 & 402 & 1 & 2 & 7 & 56 & 89 \\
\hline Alabamas & - & 0 & 2 & 4 & 5 & - & 5 & 16 & 109 & 149 & 1 & 0 & 4 & 24 & - \\
\hline Kentucky & - & 0 & 2 & 8 & 4 & - & 4 & 15 & 122 & 109 & - & 0 & 2 & 3 & 29 \\
\hline Mississippi & - & 0 & 1 & 2 & 2 & - & 1 & 6 & 26 & 42 & - & 0 & 1 & - & 1 \\
\hline Tennessee $\S$ & - & 0 & 2 & 5 & 8 & 2 & 4 & 10 & 98 & 102 & - & 1 & 6 & 29 & 59 \\
\hline W.S. Central & 2 & 1 & 9 & 48 & 45 & 14 & 67 & 753 & 1,364 & 1,356 & 1 & 4 & 40 & 19 & 440 \\
\hline Arkansas ${ }^{\S}$ & - & 0 & 2 & 5 & 5 & - & 5 & 29 & 50 & 142 & 1 & 0 & 10 & 13 & 27 \\
\hline Louisiana & - & 0 & 3 & 8 & 10 & - & 1 & 7 & 16 & 93 & - & 0 & 0 & - & - \\
\hline Oklahoma & 1 & 0 & 7 & 13 & 3 & 2 & 0 & 41 & 14 & 15 & - & 0 & 15 & 6 & 4 \\
\hline Texas $^{\S}$ & 1 & 1 & 7 & 22 & 27 & 12 & 60 & 681 & 1,284 & 1,106 & - & 3 & 30 & - & 409 \\
\hline Mountain & - & 1 & 5 & 34 & 43 & 13 & 19 & 41 & 498 & 508 & - & 1 & 8 & 21 & 51 \\
\hline Arizona & - & 0 & 2 & 9 & 8 & - & 7 & 14 & 192 & 101 & - & 0 & 5 & - & - \\
\hline Colorado & - & 0 & 3 & 11 & 13 & 5 & 2 & 13 & 59 & 139 & - & 0 & 0 & - & - \\
\hline Idaho§ & - & 0 & 1 & 5 & 6 & 1 & 2 & 19 & 79 & 47 & - & 0 & 2 & 1 & - \\
\hline Montana ${ }^{\S}$ & - & 0 & 1 & 1 & 5 & - & 1 & 8 & 31 & 12 & - & 0 & 4 & 2 & 15 \\
\hline Nevada ${ }^{5}$ & - & 0 & 1 & 5 & 3 & 7 & 0 & 6 & 15 & 7 & - & 0 & 1 & 2 & 1 \\
\hline New Mexico§ & - & 0 & 1 & 2 & 3 & - & 1 & 6 & 33 & 33 & - & 0 & 3 & 5 & 15 \\
\hline Utah & - & 0 & 1 & 1 & 1 & - & 3 & 9 & 86 & 149 & - & 0 & 2 & - & 3 \\
\hline Wyoming ${ }^{\S}$ & - & 0 & 1 & - & 4 & - & 0 & 1 & 3 & 20 & - & 0 & 3 & 11 & 17 \\
\hline Pacific & 3 & 3 & 16 & 84 & 112 & 23 & 32 & 186 & 883 & 539 & 5 & 3 & 12 & 71 & 114 \\
\hline Alaska & - & 0 & 2 & 1 & 3 & - & 0 & 6 & 12 & 29 & - & 0 & 2 & 11 & 9 \\
\hline California & 2 & 2 & 13 & 55 & 72 & 10 & 20 & 162 & 638 & 233 & 4 & 3 & 11 & 54 & 102 \\
\hline Hawaii & - & 0 & 2 & - & 3 & - & 0 & 4 & - & 19 & - & 0 & 0 & - & - \\
\hline Oregon & 1 & 1 & 5 & 19 & 25 & 1 & 6 & 14 & 150 & 115 & 1 & 0 & 2 & 6 & 3 \\
\hline Washington & - & 0 & 7 & 9 & 9 & 12 & 4 & 24 & 83 & 143 & - & 0 & 0 & - & - \\
\hline American Samoa & - & 0 & 0 & - & - & - & 0 & 0 & - & - & $\mathrm{N}$ & 0 & 0 & $\mathrm{~N}$ & $\mathrm{~N}$ \\
\hline C.N.M.I. & - & - & - & - & - & - & - & - & - & - & - & - & - & - & - \\
\hline Guam & - & 0 & 0 & - & - & - & 0 & 2 & - & - & - & 0 & 0 & - & - \\
\hline Puerto Rico & - & 0 & 1 & - & - & - & 0 & 0 & - & 1 & 1 & 1 & 3 & 23 & 23 \\
\hline U.S. Virgin Islands & - & 0 & 0 & - & - & - & 0 & 0 & - & - & - & 0 & 0 & - & - \\
\hline
\end{tabular}

C.N.M.I.: Commonwealth of Northern Mariana Islands.

U: Unavailable. - - No reported cases. N: Not reportable. NN: Not Nationally Notifiable. Cum: Cumulative year-to-date counts. Med: Median. Max: Maximum.

* Incidence data for reporting years 2009 and 2010 are provisional.

† Data for meningococcal disease, invasive caused by serogroups A, C, Y, and W-135; serogroup B; other serogroup; and unknown serogroup are available in Table I.

$\S$ Contains data reported through the National Electronic Disease Surveillance System (NEDSS). 
TABLE II. (Continued) Provisional cases of selected notifiable diseases, United States, weeks ending July 3, 2010, and July 4, 2009 (26th week)*

\begin{tabular}{|c|c|c|c|c|c|c|c|c|c|c|c|c|c|c|c|}
\hline \multirow[b]{3}{*}{ Reporting area } & \multicolumn{5}{|c|}{ Salmonellosis } & \multicolumn{5}{|c|}{ Shiga toxin-producing E. coli (STEC) ${ }^{\dagger}$} & \multicolumn{5}{|c|}{ Shigellosis } \\
\hline & \multirow{2}{*}{$\begin{array}{c}\text { Current } \\
\text { week }\end{array}$} & \multicolumn{2}{|c|}{ Previous 52 weeks } & \multirow{2}{*}{$\begin{array}{l}\text { Cum } \\
2010\end{array}$} & Cum & & Previous & 2 weeks & Cum & Cum & Current & Previous & 2 weeks & Cum & Cum \\
\hline & & Med & Max & & 2009 & week & Med & Max & 2010 & 2009 & week & Med & Max & 2010 & 2009 \\
\hline United States & 546 & 810 & 1,521 & 14,955 & 19,045 & 75 & 71 & 195 & 1,385 & 1,855 & 150 & 260 & 523 & 6,113 & 8,046 \\
\hline $\begin{array}{r}\text { New England } \\
\text { Connecticut }\end{array}$ & 4 & $\begin{array}{r}20 \\
0\end{array}$ & $\begin{array}{l}201 \\
196\end{array}$ & $\begin{array}{l}367 \\
196\end{array}$ & $\begin{array}{r}1,307 \\
430\end{array}$ & - & $\begin{array}{l}2 \\
0\end{array}$ & $\begin{array}{l}30 \\
25\end{array}$ & $\begin{array}{l}44 \\
25\end{array}$ & $\begin{array}{r}141 \\
67\end{array}$ & 二 & $\begin{array}{l}2 \\
0\end{array}$ & $\begin{array}{l}28 \\
26\end{array}$ & $\begin{array}{l}37 \\
26\end{array}$ & $\begin{array}{r}122 \\
43\end{array}$ \\
\hline Maine ${ }^{\S}$ & 1 & 2 & 7 & 45 & 57 & - & 0 & 2 & 4 & 9 & - & 0 & 2 & 3 & 2 \\
\hline Massachusetts & - & 12 & 47 & - & 530 & - & 0 & 6 & - & 40 & - & 1 & 27 & - & 64 \\
\hline New Hampshire & 1 & 3 & 9 & 69 & 179 & - & 0 & 3 & 10 & 16 & - & 0 & 5 & 3 & 2 \\
\hline Rhode Island $\$$ & - & 2 & 11 & 33 & 73 & - & 0 & 26 & - & - & - & 0 & 7 & 4 & 8 \\
\hline Vermont ${ }^{\S}$ & 2 & 1 & 5 & 24 & 38 & - & 0 & 3 & 5 & 9 & - & 0 & 1 & 1 & 3 \\
\hline Mid. Atlantic & 60 & 91 & 208 & 1,933 & 2,216 & 9 & 7 & 24 & 158 & 182 & 14 & 35 & 90 & 787 & 1,534 \\
\hline New Jersey & - & 15 & 47 & 245 & 465 & - & 1 & 5 & 16 & 54 & - & 7 & 23 & 128 & 333 \\
\hline New York (Upstate) & 26 & 24 & 78 & 513 & 490 & 5 & 3 & 15 & 71 & 44 & 3 & 4 & 19 & 82 & 98 \\
\hline New York City & - & 24 & 46 & 473 & 501 & - & 1 & 4 & 16 & 36 & - & 7 & 15 & 141 & 224 \\
\hline Pennsylvaniá & 34 & 29 & 67 & 702 & 760 & 4 & 2 & 8 & 55 & 48 & 11 & 19 & 63 & 436 & 879 \\
\hline E.N. Central & 40 & 76 & 168 & 1,759 & 2,471 & 9 & 9 & 29 & 195 & 340 & 14 & 27 & 234 & 907 & 1,531 \\
\hline Illinois & - & 24 & 52 & 564 & 696 & - & 1 & 6 & 12 & 95 & - & 9 & 227 & 525 & 356 \\
\hline Indiana & - & 8 & 31 & 58 & 283 & - & 1 & 9 & 16 & 37 & - & 1 & 5 & 18 & 41 \\
\hline Michigan & 6 & 15 & 34 & 337 & 482 & 3 & 2 & 16 & 72 & 60 & - & 3 & 10 & 101 & 135 \\
\hline Ohio & 33 & 25 & 52 & 632 & 681 & 6 & 2 & 11 & 56 & 56 & 14 & 8 & 46 & 165 & 701 \\
\hline Wisconsin & 1 & 9 & 26 & 168 & 329 & - & 2 & 11 & 39 & 92 & - & 5 & 18 & 98 & 298 \\
\hline W.N.Central & 37 & 44 & 94 & 946 & 1,254 & 9 & 11 & 41 & 250 & 273 & 31 & 48 & 88 & 1,431 & 421 \\
\hline lowa & 3 & 7 & 16 & 155 & 203 & - & 3 & 12 & 49 & 74 & - & 0 & 5 & 27 & 42 \\
\hline Kansas & 5 & 6 & 20 & 159 & 170 & 2 & 1 & 5 & 26 & 29 & 6 & 3 & 14 & 136 & 129 \\
\hline Minnesota & - & 9 & 32 & 179 & 271 & - & 2 & 17 & 31 & 61 & - & 0 & 6 & 14 & 33 \\
\hline Missouri & 20 & 13 & 29 & 311 & 254 & 4 & 2 & 29 & 104 & 56 & 25 & 44 & 75 & 1,237 & 199 \\
\hline Nebraska§ & 9 & 4 & 12 & 89 & 207 & 3 & 1 & 6 & 34 & 39 & - & 0 & 3 & 14 & 13 \\
\hline North Dakota & - & 0 & 39 & 15 & 27 & - & 0 & 7 & - & 4 & - & 0 & 5 & - & 3 \\
\hline South Dakota & - & 2 & 9 & 38 & 122 & - & 0 & 12 & 6 & 10 & - & 0 & 2 & 3 & 2 \\
\hline S. Atlantic & 207 & 251 & 503 & 4,024 & 4,638 & 13 & 12 & 23 & 235 & 307 & 31 & 40 & 71 & 895 & 1,217 \\
\hline Delaware & - & 2 & 9 & 46 & 36 & - & 0 & 2 & 1 & 8 & - & 3 & 10 & 33 & 42 \\
\hline District of Columbia & - & 2 & 6 & 34 & 46 & - & 0 & 1 & 4 & 1 & - & 0 & 4 & 16 & 14 \\
\hline Florida & 119 & 126 & 277 & 1,941 & 1,974 & 8 & 3 & 8 & 92 & 82 & 23 & 11 & 30 & 380 & 227 \\
\hline Georgia & 33 & 39 & 105 & 659 & 837 & - & 1 & 4 & 24 & 34 & 4 & 12 & 24 & 316 & 327 \\
\hline Maryland ${ }^{\S}$ & 18 & 15 & 32 & 330 & 336 & 4 & 1 & 6 & 36 & 38 & 3 & 3 & 17 & 46 & 207 \\
\hline North Carolina & - & 30 & 90 & 230 & 622 & - & 1 & 5 & 4 & 63 & - & 2 & 26 & 15 & 233 \\
\hline South Carolina ${ }^{\S}$ & 15 & 19 & 66 & 337 & 302 & 1 & 0 & 3 & 12 & 14 & 1 & 1 & 6 & 33 & 68 \\
\hline Virginias & 22 & 18 & 68 & 368 & 392 & - & 2 & 15 & 56 & 58 & - & 3 & 15 & 55 & 94 \\
\hline West Virginia & - & 3 & 23 & 79 & 93 & - & 0 & 5 & 6 & 9 & - & 0 & 2 & 1 & 5 \\
\hline E.S. Central & 19 & 50 & 118 & 935 & 1,120 & 1 & 4 & 10 & 80 & 106 & 1 & 11 & 40 & 336 & 496 \\
\hline Alabama & - & 14 & 40 & 242 & 323 & - & 1 & 4 & 21 & 25 & - & 2 & 10 & 50 & 95 \\
\hline Kentucky & - & 8 & 28 & 191 & 216 & - & 1 & 4 & 8 & 34 & - & 3 & 28 & 153 & 125 \\
\hline Mississippi & 1 & 13 & 42 & 218 & 280 & - & 0 & 2 & 10 & 6 & - & 1 & 4 & 18 & 18 \\
\hline Tennessee ${ }^{\S}$ & 18 & 13 & 33 & 284 & 301 & 1 & 1 & 8 & 41 & 41 & 1 & 5 & 13 & 115 & 258 \\
\hline W.S.Central & 50 & 104 & 547 & 1,532 & 1,985 & 3 & 4 & 68 & 75 & 124 & 41 & 48 & 251 & 1,025 & 1,575 \\
\hline Arkansas $^{\S}$ & 23 & 10 & 25 & 192 & 228 & 1 & 1 & 5 & 23 & 13 & 1 & 2 & 11 & 24 & 180 \\
\hline Louisiana & 1 & 17 & 46 & 330 & 415 & - & 0 & 3 & 5 & 14 & 2 & 3 & 9 & 101 & 112 \\
\hline Oklahoma & 9 & 10 & 46 & 198 & 240 & 2 & 0 & 27 & 6 & 9 & 1 & 7 & 96 & 149 & 110 \\
\hline Texas ${ }^{\S}$ & 17 & 60 & 477 & 812 & 1,102 & - & 3 & 41 & 41 & 88 & 37 & 34 & 144 & 751 & 1,173 \\
\hline Mountain & 29 & 49 & 133 & 1,066 & 1,338 & 13 & 7 & 26 & 158 & 222 & 4 & 14 & 43 & 288 & 601 \\
\hline Arizona & 4 & 18 & 50 & 343 & 446 & 1 & 1 & 5 & 33 & 30 & 2 & 9 & 38 & 155 & 434 \\
\hline Colorado & 12 & 11 & 33 & 264 & 282 & 9 & 2 & 11 & 33 & 83 & 1 & 2 & 6 & 47 & 41 \\
\hline Idaho§ & 3 & 3 & 10 & 66 & 81 & 2 & 1 & 7 & 23 & 29 & - & 0 & 3 & 9 & 3 \\
\hline Montana $a^{\S}$ & - & 2 & 7 & 48 & 62 & - & 1 & 7 & 23 & 11 & - & 0 & 1 & 4 & 11 \\
\hline Nevadas & 9 & 4 & 14 & 106 & 119 & 1 & 0 & 4 & 12 & 13 & 1 & 1 & 7 & 16 & 32 \\
\hline New Mexico§ & - & 5 & 40 & 96 & 153 & - & 1 & 3 & 13 & 19 & - & 1 & 6 & 47 & 67 \\
\hline Utah & - & 5 & 15 & 125 & 154 & - & 1 & 11 & 17 & 35 & - & 0 & 4 & 10 & 12 \\
\hline Wyoming§ & 1 & 1 & 9 & 18 & 41 & - & 0 & 2 & 4 & 2 & - & 0 & 2 & - & 1 \\
\hline Pacific & 100 & 116 & 299 & 2,393 & 2,716 & 18 & 9 & 46 & 190 & 160 & 14 & 21 & 64 & 407 & 549 \\
\hline Alaska & - & 1 & 6 & 41 & 31 & - & 0 & 1 & 1 & 1 & - & 0 & 2 & - & 1 \\
\hline California & 68 & 84 & 227 & 1,753 & 2,076 & 11 & 4 & 35 & 88 & 96 & 10 & 16 & 51 & 345 & 431 \\
\hline Hawaii & 8 & 4 & 62 & 20 & 124 & - & 0 & 4 & 6 & 3 & 1 & 0 & 4 & 3 & 16 \\
\hline Oregon & 4 & 8 & 49 & 283 & 207 & - & 1 & 11 & 29 & 14 & - & 1 & 4 & 27 & 25 \\
\hline Washington & 20 & 15 & 61 & 296 & 278 & 7 & 3 & 19 & 66 & 46 & 3 & 2 & 9 & 32 & 76 \\
\hline American Samoa & 1 & 1 & 1 & 2 & - & - & 0 & 0 & - & - & - & 1 & 1 & 1 & 3 \\
\hline $\begin{array}{l}\text { C.N.M.I. } \\
\text { L. }\end{array}$ & - & - & - & - & - & - & - & - & - & - & - & - & - & - & - \\
\hline Guam & - & 0 & 2 & 2 & 5 & - & 0 & 0 & - & - & - & 0 & 3 & 1 & 3 \\
\hline Puerto Rico & 4 & 7 & 39 & 101 & 260 & - & 0 & 0 & - & - & - & 0 & 1 & - & 7 \\
\hline U.S. Virgin Islands & - & 0 & 0 & - & - & - & 0 & 0 & - & - & - & 0 & 0 & - & - \\
\hline
\end{tabular}

C.N.M.I.: Commonwealth of Northern Mariana Islands.

U: Unavailable. - - No reported cases. N: Not reportable. NN: Not Nationally Notifiable. Cum: Cumulative year-to-date counts. Med: Median. Max: Maximum. * Incidence data for reporting years 2009 and 2010 are provisional.

† Includes E. coli O157:H7; Shiga toxin-positive, serogroup non-O157; and Shiga toxin-positive, not serogrouped.

$\S$ Contains data reported through the National Electronic Disease Surveillance System (NEDSS). 
MMWR Morbidity and Mortality Weekly Report

TABLE II. (Continued) Provisional cases of selected notifiable diseases, United States, weeks ending July 3, 2010, and July 4, 2009 (26th week)*

\begin{tabular}{|c|c|c|c|c|c|c|c|c|c|c|}
\hline \multirow[b]{4}{*}{ Reporting area } & \multicolumn{10}{|c|}{ Spotted Fever Rickettsiosis (including RMSF) ${ }^{\dagger}$} \\
\hline & \multicolumn{5}{|c|}{ Confirmed } & \multicolumn{5}{|c|}{ Probable } \\
\hline & \multirow{2}{*}{$\begin{array}{c}\text { Current } \\
\text { week }\end{array}$} & \multicolumn{2}{|c|}{ Previous 52 weeks } & \multirow{2}{*}{$\begin{array}{l}\text { Cum } \\
2010\end{array}$} & \multirow{2}{*}{$\begin{array}{l}\text { Cum } \\
2009 \\
\end{array}$} & & Previous & 2 weeks & Cum & Cum \\
\hline & & Med & Max & & & week & Med & Max & 2010 & 2009 \\
\hline United States & 1 & 2 & 8 & 41 & 68 & 12 & 13 & 416 & 336 & 630 \\
\hline New England & - & 0 & 1 & - & 1 & - & 0 & 1 & 1 & 8 \\
\hline Connecticut & - & 0 & 0 & - & - & - & 0 & 0 & - & - \\
\hline Maine ${ }^{\S}$ & - & 0 & 0 & - & - & - & 0 & 1 & 1 & 4 \\
\hline Massachusetts & - & 0 & 0 & - & 1 & - & 0 & 1 & - & 4 \\
\hline New Hampshire & - & 0 & 0 & - & - & - & 0 & 1 & - & - \\
\hline Rhode Island $\$$ & - & 0 & 0 & - & - & - & 0 & 0 & - & - \\
\hline Vermont ${ }^{\S}$ & - & 0 & 1 & - & - & - & 0 & 0 & - & - \\
\hline Mid. Atlantic & - & 0 & 3 & 10 & 2 & - & 1 & 6 & 17 & 49 \\
\hline New Jersey & - & 0 & 1 & - & 1 & - & 0 & 3 & - & 35 \\
\hline New York (Upstate) & - & 0 & 1 & 1 & - & - & 0 & 3 & 3 & 2 \\
\hline New York City & - & 0 & 1 & 2 & - & - & 0 & 2 & 8 & 5 \\
\hline Pennsylvania & - & 0 & 2 & 7 & 1 & - & 0 & 1 & 6 & 7 \\
\hline E.N. Central & - & 0 & 1 & 1 & 5 & 2 & 0 & 5 & 19 & 50 \\
\hline Illinois & - & 0 & 1 & 1 & - & - & 0 & 3 & 6 & 34 \\
\hline Indiana & - & 0 & 0 & - & 3 & 2 & 0 & 2 & 9 & 5 \\
\hline Michigan & - & 0 & 1 & - & 1 & - & 0 & 2 & 3 & - \\
\hline Ohio & - & 0 & 0 & - & - & - & 0 & 4 & 1 & 9 \\
\hline Wisconsin & - & 0 & 0 & - & 1 & - & 0 & 1 & - & 2 \\
\hline W.N.Central & 1 & 0 & 3 & 6 & 7 & 3 & 2 & 23 & 101 & 113 \\
\hline lowa & - & 0 & 1 & - & - & - & 0 & 1 & - & 2 \\
\hline Kansas & - & 0 & 1 & 2 & 1 & - & 0 & 0 & - & - \\
\hline Minnesota & - & 0 & 1 & - & - & - & 0 & 1 & - & - \\
\hline Missouri & 1 & 0 & 1 & 3 & 3 & 3 & 2 & 22 & 100 & 110 \\
\hline Nebraska ${ }^{\S}$ & - & 0 & 2 & 1 & 3 & - & 0 & 1 & 1 & 1 \\
\hline North Dakota & - & 0 & 0 & - & - & - & 0 & 0 & - & - \\
\hline South Dakota & - & 0 & 0 & - & - & - & 0 & 0 & - & - \\
\hline S. Atlantic & - & 0 & 3 & 13 & 42 & 4 & 3 & 31 & 86 & 206 \\
\hline Delaware & - & 0 & 1 & 1 & - & - & 0 & 3 & 5 & 4 \\
\hline District of Columbia & - & 0 & 0 & - & - & - & 0 & 1 & - & - \\
\hline Florida & - & 0 & 1 & 1 & - & - & 0 & 2 & 8 & 2 \\
\hline Georgia & - & 0 & 3 & 9 & 35 & - & 0 & 0 & - & - \\
\hline Maryland $^{\S}$ & - & 0 & 1 & 1 & 2 & 2 & 0 & 3 & 8 & 30 \\
\hline North Carolina & - & 0 & 1 & 1 & 3 & - & 1 & 23 & 27 & 131 \\
\hline South Carolina ${ }^{\S}$ & - & 0 & 1 & - & 2 & - & 0 & 1 & 3 & 13 \\
\hline Virginia $\$$ & - & 0 & 1 & - & - & 2 & 0 & 7 & 35 & 26 \\
\hline West Virginia & - & 0 & 0 & - & - & - & 0 & 1 & - & - \\
\hline E.S.Central & - & 0 & 2 & 4 & 2 & 2 & 3 & 16 & 95 & 124 \\
\hline Alabamas & - & 0 & 1 & - & 1 & - & 1 & 7 & 19 & 26 \\
\hline Kentucky & - & 0 & 1 & 2 & 1 & - & 0 & 0 & - & - \\
\hline Mississippi & - & 0 & 0 & - & - & - & 0 & 1 & - & 8 \\
\hline Tennessee ${ }^{\S}$ & - & 0 & 2 & 2 & - & 2 & 2 & 13 & 76 & 90 \\
\hline W.S.Central & - & 0 & 3 & 1 & 1 & 1 & 1 & 408 & 13 & 67 \\
\hline Arkansas ${ }^{\S}$ & - & 0 & 1 & - & - & - & 0 & 110 & - & 43 \\
\hline Louisiana & - & 0 & 0 & - & - & - & 0 & 0 & - & 2 \\
\hline Oklahoma & - & 0 & 3 & - & - & 1 & 0 & 287 & 9 & 10 \\
\hline Texas $^{\S}$ & - & 0 & 1 & 1 & 1 & - & 0 & 11 & 4 & 12 \\
\hline Mountain & - & 0 & 2 & 2 & 7 & - & 0 & 3 & 4 & 13 \\
\hline Arizona & - & 0 & 2 & - & 2 & - & 0 & 2 & 1 & 5 \\
\hline Colorado & - & 0 & 1 & - & - & - & 0 & 0 & - & - \\
\hline Idaho $^{\S}$ & - & 0 & 0 & - & - & - & 0 & 1 & 1 & - \\
\hline Montana ${ }^{\S}$ & - & 0 & 1 & 2 & 4 & - & 0 & 1 & 1 & 5 \\
\hline Nevada ${ }^{\S}$ & - & 0 & 0 & - & - & - & 0 & 1 & - & 1 \\
\hline New Mexico§ & - & 0 & 0 & - & - & - & 0 & 1 & 1 & 1 \\
\hline Utah & - & 0 & 0 & - & - & - & 0 & 0 & - & 1 \\
\hline Wyoming $^{\S}$ & - & 0 & 0 & - & 1 & - & 0 & 1 & - & - \\
\hline Pacific & - & 0 & 2 & 4 & 1 & - & 0 & 0 & - & - \\
\hline Alaska & $\mathrm{N}$ & 0 & 0 & $\mathrm{~N}$ & $\mathrm{~N}$ & $\mathrm{~N}$ & 0 & 0 & $\mathrm{~N}$ & $\mathrm{~N}$ \\
\hline California & - & 0 & 2 & 4 & 1 & - & 0 & 0 & - & - \\
\hline Hawaii & $\mathrm{N}$ & 0 & 0 & $\mathrm{~N}$ & $\mathrm{~N}$ & $\mathrm{~N}$ & 0 & 0 & $\mathrm{~N}$ & $\mathrm{~N}$ \\
\hline Oregon & - & 0 & 0 & - & - & - & 0 & 0 & - & - \\
\hline Washington & - & 0 & 0 & - & - & - & 0 & 0 & - & - \\
\hline American Samoa & $\mathrm{N}$ & 0 & 0 & $\mathrm{~N}$ & $\mathrm{~N}$ & $\mathrm{~N}$ & 0 & 0 & $\mathrm{~N}$ & $\mathrm{~N}$ \\
\hline C.N.M.I. & - & - & - & - & $\bar{x}$ & - & - & - & - & $\overline{-}$ \\
\hline Guam & $\mathrm{N}$ & 0 & 0 & $\mathrm{~N}$ & $\mathrm{~N}$ & $\mathrm{~N}$ & 0 & 0 & $\mathrm{~N}$ & $\mathrm{~N}$ \\
\hline Puerto Rico & $\mathrm{N}$ & 0 & 0 & $\mathrm{~N}$ & $\mathrm{~N}$ & $\mathrm{~N}$ & 0 & 0 & $\mathrm{~N}$ & $\mathrm{~N}$ \\
\hline U.S. Virgin Islands & - & 0 & 0 & - & - & - & 0 & 0 & - & - \\
\hline
\end{tabular}

C.N.M.I.: Commonwealth of Northern Mariana Islands.

U: Unavailable. - - No reported cases. N: Not reportable. NN: Not Nationally Notifiable. Cum: Cumulative year-to-date counts. Med: Median. Max: Maximum.

* Incidence data for reporting years 2009 and 2010 are provisional.

† Illnesses with similar clinical presentation that result from Spotted fever group rickettsia infections are reported as Spotted fever rickettsioses. Rocky Mountain spotted fever (RMSF) caused by Rickettsia rickettsii, is the most common and well-known spotted fever.

$\S$ Contains data reported through the National Electronic Disease Surveillance System (NEDSS). 
TABLE II. (Continued) Provisional cases of selected notifiable diseases, United States, weeks ending July 3, 2010, and July 4, 2009 (26th week)*

\begin{tabular}{|c|c|c|c|c|c|c|c|c|c|c|c|c|c|c|c|}
\hline \multirow[b]{4}{*}{ Reporting area } & \multicolumn{10}{|c|}{ Streptococcus pneumoniae, ${ }^{\dagger}$ invasive disease } & & & & & \\
\hline & \multicolumn{5}{|c|}{ All ages } & \multicolumn{5}{|c|}{ Age $<5$} & \multicolumn{5}{|c|}{ Syphilis, primary and secondary } \\
\hline & \multirow{2}{*}{$\begin{array}{l}\text { Current } \\
\text { week }\end{array}$} & Previous & 2 weeks & Cum & Cum & Current. & Previous: & 2 weeks & Cum & Cum & & Previous & 2 weeks & Cum & Cum \\
\hline & & Med & Max & 2010 & 2009 & week & Med & Max & 2010 & 2009 & week & Med & Max & 2010 & 2009 \\
\hline United States & 84 & 152 & 477 & 8,681 & 1,863 & 12 & 48 & 156 & 1,329 & 1,369 & 84 & 235 & 413 & 5,238 & 6,866 \\
\hline New England & 17 & 4 & 98 & 465 & 30 & - & 1 & 24 & 36 & 45 & 9 & 7 & 22 & 223 & 158 \\
\hline Connecticut & 17 & 0 & 93 & 241 & - & - & 0 & 22 & 22 & - & - & 1 & 10 & 39 & 32 \\
\hline Maine ${ }^{\S}$ & - & 1 & 6 & 72 & 8 & - & 0 & 2 & 6 & 2 & - & 0 & 3 & 14 & 1 \\
\hline Massachusetts & - & 0 & 1 & - & 2 & - & 0 & 3 & - & 34 & 8 & 5 & 12 & 140 & 111 \\
\hline New Hampshire & - & 0 & 7 & 59 & - & - & 0 & 2 & 3 & 6 & - & 0 & 1 & 10 & 10 \\
\hline Rhode Island ${ }^{\S}$ & - & 0 & 7 & 40 & 11 & - & 0 & 1 & 2 & 1 & 1 & 0 & 5 & 18 & 4 \\
\hline Vermont ${ }^{\S}$ & - & 0 & 6 & 53 & 9 & - & 0 & 1 & 3 & 2 & - & 0 & 2 & 2 & - \\
\hline Mid. Atlantic & 4 & 10 & 52 & 733 & 111 & 1 & 7 & 48 & 208 & 172 & 29 & 33 & 47 & 829 & 898 \\
\hline New Jersey & - & 0 & 8 & 65 & - & - & 1 & 4 & 36 & 27 & 1 & 4 & 12 & 116 & 128 \\
\hline New York (Upstate) & 1 & 3 & 12 & 106 & 44 & 1 & 3 & 19 & 77 & 80 & 1 & 2 & 11 & 52 & 54 \\
\hline New York City & - & 2 & 25 & 255 & 4 & - & 1 & 24 & 59 & 53 & 22 & 18 & 39 & 476 & 545 \\
\hline Pennsylvania & 3 & 4 & 22 & 307 & 63 & - & 0 & 5 & 36 & 12 & 5 & 7 & 14 & 185 & 171 \\
\hline E.N.Central & 15 & 22 & 96 & 1,740 & 435 & 2 & 8 & 18 & 208 & 226 & 1 & 27 & 44 & 479 & 732 \\
\hline Illinois & - & 0 & 7 & 51 & - & - & 1 & 5 & 45 & 36 & - & 12 & 21 & 127 & 356 \\
\hline Indiana & - & 6 & 23 & 342 & 174 & - & 1 & 6 & 29 & 45 & - & 3 & 9 & 58 & 74 \\
\hline Michigan & - & 2 & 26 & 412 & 19 & - & 1 & 6 & 49 & 45 & - & 4 & 13 & 110 & 118 \\
\hline Ohio & 13 & 13 & 49 & 747 & 242 & 2 & 2 & 6 & 59 & 77 & - & 7 & 13 & 164 & 157 \\
\hline Wisconsin & 2 & 0 & 22 & 188 & - & - & 1 & 4 & 26 & 23 & 1 & 0 & 3 & 20 & 27 \\
\hline W.N. Central & 5 & 6 & 182 & 546 & 113 & - & 3 & 12 & 99 & 97 & 2 & 5 & 12 & 132 & 150 \\
\hline lowa & - & 0 & 0 & - & - & - & 0 & 0 & - & - & - & 0 & 2 & 4 & 13 \\
\hline Kansas & 1 & 1 & 7 & 61 & 43 & - & 0 & 2 & 11 & 14 & - & 0 & 3 & 10 & 12 \\
\hline Minnesota & - & 1 & 179 & 287 & 20 & - & 1 & 10 & 44 & 32 & 2 & 1 & 5 & 44 & 36 \\
\hline Missouri & 2 & 1 & 9 & 74 & 41 & - & 0 & 3 & 27 & 34 & - & 3 & 8 & 69 & 82 \\
\hline Nebraska ${ }^{\S}$ & 2 & 1 & 7 & 82 & - & - & 0 & 2 & 10 & 6 & - & 0 & 1 & 5 & 4 \\
\hline North Dakota & - & 0 & 11 & 31 & 7 & - & 0 & 1 & 2 & 4 & - & 0 & 1 & - & 3 \\
\hline South Dakota & - & 0 & 3 & 11 & 2 & - & 0 & 2 & 5 & 7 & - & 0 & 0 & - & - \\
\hline S. Atlantic & 21 & 36 & 143 & 2,016 & 837 & 5 & 12 & 28 & 346 & 333 & 19 & 58 & 218 & 1,293 & 1,609 \\
\hline Delaware & - & 0 & 3 & 21 & 11 & - & 0 & 2 & - & - & - & 0 & 3 & 3 & 17 \\
\hline District of Columbia & - & 0 & 4 & 20 & 16 & - & 0 & 2 & 7 & 3 & - & 2 & 8 & 58 & 91 \\
\hline Florida & 9 & 18 & 89 & 956 & 497 & 3 & 3 & 18 & 127 & 126 & 1 & 19 & 31 & 442 & 557 \\
\hline Georgia & 1 & 10 & 28 & 319 & 236 & 1 & 4 & 12 & 92 & 76 & - & 14 & 167 & 250 & 337 \\
\hline Maryland ${ }^{\S}$ & 3 & 0 & 25 & 277 & 4 & 1 & 1 & 6 & 34 & 52 & 7 & 6 & 12 & 139 & 132 \\
\hline North Carolina & - & 0 & 0 & - & - & - & 0 & 0 & - & - & - & 9 & 31 & 200 & 264 \\
\hline South Carolina ${ }^{\S}$ & 8 & 0 & 25 & 317 & - & - & 1 & 4 & 35 & 31 & 1 & 2 & 6 & 63 & 63 \\
\hline Virginia $\$$ & - & 0 & 4 & 39 & - & - & 1 & 4 & 37 & 30 & 10 & 4 & 22 & 135 & 144 \\
\hline West Virginia & - & 1 & 21 & 67 & 73 & - & 0 & 4 & 14 & 15 & - & 0 & 2 & 3 & 4 \\
\hline E.S.Central & 4 & 12 & 50 & 769 & 188 & 1 & 2 & 8 & 75 & 80 & 6 & 20 & 39 & 432 & 566 \\
\hline Alabama & - & 0 & 0 & - & - & - & 0 & 0 & - & - & - & 6 & 17 & 113 & 232 \\
\hline Kentucky & - & 2 & 16 & 109 & 52 & - & 0 & 2 & 9 & 7 & 5 & 2 & 13 & 66 & 26 \\
\hline Mississippi & - & 1 & 6 & 38 & 31 & - & 0 & 2 & 8 & 12 & - & 5 & 17 & 94 & 95 \\
\hline Tennessee $^{\S}$ & 4 & 8 & 44 & 622 & 105 & 1 & 2 & 7 & 58 & 61 & 1 & 7 & 16 & 159 & 213 \\
\hline W.S.Central & 12 & 7 & 89 & 1,109 & 73 & 2 & 6 & 41 & 177 & 207 & 12 & 41 & 72 & 731 & 1,398 \\
\hline Arkansas & 4 & 2 & 9 & 105 & 34 & - & 0 & 3 & 10 & 26 & 10 & 4 & 14 & 75 & 98 \\
\hline Louisiana & - & 1 & 8 & 47 & 39 & - & 0 & 3 & 16 & 17 & - & 6 & 27 & 64 & 407 \\
\hline Oklahoma & 1 & 0 & 5 & 32 & - & 1 & 1 & 5 & 32 & 33 & 2 & 1 & 6 & 33 & 46 \\
\hline Texas $^{\S}$ & 7 & 0 & 82 & 925 & - & 1 & 3 & 34 & 119 & 131 & - & 27 & 46 & 559 & 847 \\
\hline Mountain & 6 & 5 & 83 & 1,124 & 74 & 1 & 5 & 12 & 156 & 190 & 1 & 8 & 18 & 175 & 272 \\
\hline Arizona & 2 & 0 & 52 & 539 & - & - & 2 & 7 & 71 & 84 & - & 3 & 10 & 59 & 130 \\
\hline Colorado & 4 & 0 & 20 & 320 & - & 1 & 1 & 4 & 41 & 28 & - & 2 & 5 & 54 & 46 \\
\hline Idaho§ & - & 0 & 1 & 8 & - & - & 0 & 1 & 4 & 6 & - & 0 & 1 & 2 & 3 \\
\hline Montana ${ }^{\S}$ & - & 0 & 2 & 13 & - & - & 0 & 1 & 1 & - & - & 0 & 1 & - & - \\
\hline $\mathrm{Nevada}^{\S}$ & - & 1 & 4 & 46 & 28 & - & 0 & 1 & 4 & 6 & 1 & 1 & 10 & 42 & 53 \\
\hline New Mexico§ & - & 0 & 8 & 96 & - & - & 0 & 4 & 13 & 23 & - & 1 & 4 & 13 & 24 \\
\hline Utah & - & 2 & 9 & 94 & 37 & - & 1 & 4 & 20 & 42 & - & 0 & 2 & 5 & 15 \\
\hline Wyoming $\$$ & - & 0 & 1 & 8 & 9 & - & 0 & 1 & 2 & 1 & - & 0 & 1 & - & 1 \\
\hline Pacific & - & 1 & 14 & 179 & 2 & - & 0 & 7 & 24 & 19 & 5 & 38 & 62 & 944 & 1,083 \\
\hline Alaska & - & 0 & 9 & 68 & - & - & 0 & 5 & 16 & 11 & - & 0 & 0 & - & - \\
\hline California & - & 0 & 12 & 111 & - & - & 0 & 2 & 8 & - & 4 & 35 & 57 & 847 & 963 \\
\hline Hawaii & - & 0 & 1 & - & 2 & - & 0 & 1 & - & 8 & - & 0 & 3 & 18 & 19 \\
\hline Oregon & - & 0 & 0 & - & - & - & 0 & 0 & - & - & - & 0 & 5 & 6 & 29 \\
\hline Washington & - & 0 & 0 & - & - & - & 0 & 0 & - & - & 1 & 3 & 7 & 73 & 72 \\
\hline & - & 0 & 0 & - & - & - & 0 & 0 & - & - & - & 0 & 0 & - & - \\
\hline $\begin{array}{l}\text { C.N.M.I. } \\
\text { (1) }\end{array}$ & - & - & - & - & - & - & - & - & - & - & - & - & - & - & - \\
\hline Guam & - & 0 & 0 & - & - & - & 0 & 0 & - & - & - & 0 & 0 & - & - \\
\hline Puerto Rico & - & 0 & 0 & - & - & - & 0 & 0 & - & - & - & 3 & 17 & 104 & 109 \\
\hline U.S. Virgin Islands & - & 0 & 0 & - & - & - & 0 & 0 & - & - & - & 0 & 0 & - & - \\
\hline
\end{tabular}

C.N.M.I.: Commonwealth of Northern Mariana Islands.

U: Unavailable. - - No reported cases. N: Not reportable. NN: Not Nationally Notifiable. Cum: Cumulative year-to-date counts. Med: Median. Max: Maximum.

* Incidence data for reporting years 2009 and 2010 are provisional.

+ Includes drug resistant and susceptible cases of invasive Streptococcus pneumoniae disease among children $<5$ years and among all ages. Case definition: Isolation of S. pneumoniae from a normally sterile body site (e.g., blood or cerebrospinal fluid).

$\S$ Contains data reported through the National Electronic Disease Surveillance System (NEDSS). 


\begin{tabular}{|c|c|c|c|c|c|c|c|c|c|c|c|c|c|c|c|}
\hline \multirow[b]{4}{*}{ Reporting area } & & & & & & \multicolumn{10}{|c|}{ West Nile virus disease $^{\dagger}$} \\
\hline & \multicolumn{5}{|c|}{ Varicella (chickenpox) } & \multicolumn{5}{|c|}{ Neuroinvasive } & \multicolumn{5}{|c|}{ Nonneuroinvasive } \\
\hline & \multirow{2}{*}{$\begin{array}{c}\text { Current } \\
\text { week }\end{array}$} & Previous & 2 weeks & Cum & Cum & & Previous & 2 weeks & Cum & Cum & Current & Previous & 2 weeks & Cum & Cum \\
\hline & & Med & Max & 2010 & 2009 & week & Med & $\operatorname{Max}$ & 2010 & 2009 & week & Med & Max & 2010 & 2009 \\
\hline United States & 63 & 330 & 535 & 8,405 & 13,665 & - & 0 & 46 & 1 & 23 & - & 0 & 49 & 3 & 18 \\
\hline New England & 2 & $\begin{array}{r}17 \\
7\end{array}$ & $\begin{array}{l}36 \\
20\end{array}$ & $\begin{array}{l}383 \\
176\end{array}$ & $\begin{array}{l}617 \\
296\end{array}$ & - & $\begin{array}{l}0 \\
0\end{array}$ & $\begin{array}{l}0 \\
0\end{array}$ & $\overline{-}$ & $\overline{-}$ & $\overline{-}$ & $\begin{array}{l}0 \\
0\end{array}$ & $\begin{array}{l}0 \\
0\end{array}$ & - & - \\
\hline Maine ${ }^{\S}$ & - & 4 & $\begin{array}{l}20 \\
15\end{array}$ & 107 & $\begin{array}{l}296 \\
107\end{array}$ & - & $\begin{array}{l}0 \\
0\end{array}$ & $\begin{array}{l}0 \\
0\end{array}$ & - & $\overline{-}$ & - & $\begin{array}{l}0 \\
0\end{array}$ & $\begin{array}{l}0 \\
0\end{array}$ & - & - \\
\hline Massachusetts & - & 0 & 1 & - & 3 & - & 0 & 0 & - & - & - & 0 & 0 & - & - \\
\hline New Hampshire & - & 3 & 8 & 72 & 125 & - & 0 & 0 & - & - & - & 0 & 0 & - & - \\
\hline Rhode Island ${ }^{\S}$ & - & 1 & 12 & 16 & 22 & - & 0 & 0 & - & - & - & 0 & 0 & - & - \\
\hline Vermont $^{\S}$ & - & 1 & 10 & 12 & 64 & - & 0 & 0 & - & - & - & 0 & 0 & - & - \\
\hline Mid. Atlantic & 6 & 33 & 66 & 919 & 1,289 & - & 0 & 2 & - & - & - & 0 & 1 & - & - \\
\hline New Jersey & - & 9 & 30 & 340 & 269 & - & 0 & 1 & - & - & - & 0 & 0 & - & - \\
\hline New York (Upstate) & $\mathrm{N}$ & 0 & 0 & $\mathrm{~N}$ & $\mathrm{~N}$ & - & 0 & 1 & - & - & - & 0 & 1 & - & - \\
\hline New York City & - & 0 & 0 & - & - & - & 0 & 1 & - & - & - & 0 & 0 & - & - \\
\hline Pennsylvania & 6 & 22 & 52 & 579 & 1,020 & - & 0 & 0 & - & - & - & 0 & 0 & - & - \\
\hline E.N. Central & 19 & 108 & 176 & 2,957 & 4,298 & - & 0 & 4 & - & - & - & 0 & 3 & - & - \\
\hline Illinois & 1 & 26 & 49 & 738 & 1,007 & - & 0 & 3 & - & - & - & 0 & 0 & - & - \\
\hline Indiana ${ }^{\S}$ & 9 & 5 & 35 & 274 & 313 & - & 0 & 1 & - & - & - & 0 & 1 & - & - \\
\hline Michigan & 3 & 35 & 62 & 942 & 1,263 & - & 0 & 1 & - & - & - & 0 & 0 & - & - \\
\hline Ohio & 6 & 28 & 56 & 820 & 1,335 & - & 0 & 0 & - & - & - & 0 & 2 & - & - \\
\hline Wisconsin & - & 7 & 24 & 183 & 380 & - & 0 & 1 & - & - & - & 0 & 0 & - & - \\
\hline W.N.Central & 7 & 13 & 40 & 334 & 890 & - & 0 & 5 & - & 2 & - & 0 & 11 & 1 & 6 \\
\hline lowa & $\mathrm{N}$ & 0 & 0 & $\mathrm{~N}$ & $\mathrm{~N}$ & - & 0 & 0 & - & - & - & 0 & 1 & - & - \\
\hline Kansas $^{\S}$ & - & 4 & 18 & 97 & 376 & - & 0 & 1 & - & - & - & 0 & 2 & - & 1 \\
\hline Minnesota & - & 0 & 0 & - & - & - & 0 & 1 & - & - & - & 0 & 1 & - & 1 \\
\hline Missouri & 7 & 6 & 16 & 199 & 425 & - & 0 & 2 & - & 1 & - & 0 & 1 & - & - \\
\hline Nebraska ${ }^{\S}$ & $\mathrm{N}$ & 0 & 0 & $\mathrm{~N}$ & $\mathrm{~N}$ & - & 0 & 2 & - & - & - & 0 & 6 & - & 2 \\
\hline North Dakota & - & 0 & 26 & 29 & 54 & - & 0 & 0 & - & - & - & 0 & 1 & 1 & - \\
\hline South Dakota & - & 0 & 7 & 9 & 35 & - & 0 & 3 & - & 1 & - & 0 & 2 & - & 2 \\
\hline S. Atlantic & 6 & 36 & 101 & 1,267 & 1,669 & - & 0 & 4 & - & - & - & 0 & 2 & 2 & - \\
\hline Delaware ${ }^{\S}$ & - & 0 & 6 & 27 & 7 & - & 0 & 0 & - & - & - & 0 & 0 & - & - \\
\hline District of Columbia & - & 0 & 4 & 13 & 21 & - & 0 & 1 & - & - & - & 0 & 0 & - & - \\
\hline Florida $^{\S}$ & - & 15 & 57 & 639 & 854 & - & 0 & 1 & - & - & - & 0 & 1 & - & - \\
\hline Georgia & $\mathrm{N}$ & 0 & 0 & $\mathrm{~N}$ & $\mathrm{~N}$ & - & 0 & 1 & - & - & - & 0 & 1 & 2 & - \\
\hline Maryland ${ }^{\S}$ & $\mathrm{N}$ & 0 & 0 & $\mathrm{~N}$ & $\mathrm{~N}$ & - & 0 & 0 & - & - & - & 0 & 1 & - & - \\
\hline North Carolina & $\mathrm{N}$ & 0 & 0 & $\mathrm{~N}$ & $\mathrm{~N}$ & - & 0 & 0 & - & - & - & 0 & 0 & - & - \\
\hline South Carolina ${ }^{\S}$ & - & 0 & 34 & 72 & 91 & - & 0 & 2 & - & - & - & 0 & 0 & - & - \\
\hline Virginia $^{\S}$ & 3 & 11 & 34 & 265 & 448 & - & 0 & 2 & - & - & - & 0 & 0 & - & - \\
\hline West Virginia & 3 & 8 & 26 & 251 & 248 & - & 0 & 0 & - & - & - & 0 & 0 & - & - \\
\hline E.S. Central & 2 & 6 & 28 & 175 & 351 & - & 0 & 6 & 1 & 3 & - & 0 & 4 & - & 1 \\
\hline Alabama ${ }^{\S}$ & 2 & 6 & 27 & 173 & 348 & - & 0 & 0 & - & - & - & 0 & 0 & - & - \\
\hline Kentucky & $\mathrm{N}$ & 0 & 0 & $\mathrm{~N}$ & $\mathrm{~N}$ & - & 0 & 1 & - & 1 & - & 0 & 0 & - & - \\
\hline Mississippi & - & 0 & 1 & 2 & 3 & - & 0 & 5 & 1 & 1 & - & 0 & 4 & - & 1 \\
\hline Tennessee ${ }^{\S}$ & $\mathrm{N}$ & 0 & 0 & $\mathrm{~N}$ & $\mathrm{~N}$ & - & 0 & 2 & - & 1 & - & 0 & 1 & - & - \\
\hline W.S. Central & 21 & 66 & 285 & 1,723 & 3,245 & - & 0 & 19 & - & 7 & - & 0 & 6 & - & 1 \\
\hline Arkansas ${ }^{\S}$ & - & 3 & 32 & 106 & 313 & - & 0 & 1 & - & 2 & - & 0 & 0 & - & - \\
\hline Louisiana & - & 2 & 10 & 64 & 73 & - & 0 & 2 & - & 2 & - & 0 & 4 & - & - \\
\hline Oklahoma & $\mathrm{N}$ & 0 & 0 & $\mathrm{~N}$ & $\mathrm{~N}$ & - & 0 & 2 & - & - & - & 0 & 2 & - & - \\
\hline Texas ${ }^{\S}$ & 21 & 56 & 272 & 1,553 & 2,859 & - & 0 & 16 & - & 3 & - & 0 & 4 & - & 1 \\
\hline Mountain & - & 25 & 48 & 628 & 1,231 & - & 0 & 12 & - & 7 & - & 0 & 17 & - & 9 \\
\hline Arizona & - & 0 & 0 & - & - & - & 0 & 4 & - & 3 & - & 0 & 2 & - & 1 \\
\hline Colorado§ & - & 10 & 41 & 239 & 662 & - & 0 & 7 & - & - & - & 0 & 14 & - & 2 \\
\hline Idaho§ & $\mathrm{N}$ & 0 & 0 & $\mathrm{~N}$ & $\mathrm{~N}$ & - & 0 & 3 & - & 1 & - & 0 & 5 & - & 1 \\
\hline Montana $a^{\S}$ & - & 3 & 17 & 129 & 108 & - & 0 & 1 & - & - & - & 0 & 1 & - & - \\
\hline Nevadas & $\mathrm{N}$ & 0 & 0 & $\mathrm{~N}$ & $\mathrm{~N}$ & - & 0 & 2 & - & 3 & - & 0 & 1 & - & 3 \\
\hline New Mexico§ & - & 1 & 7 & 59 & 86 & - & 0 & 2 & - & - & - & 0 & 1 & - & - \\
\hline Utah & - & 6 & 22 & 188 & 375 & - & 0 & 1 & - & - & - & 0 & 0 & - & 1 \\
\hline Wyoming ${ }^{\S}$ & - & 0 & 3 & 13 & - & - & 0 & 1 & - & - & - & 0 & 2 & - & 1 \\
\hline Pacific & - & 0 & 5 & 19 & 75 & - & 0 & 12 & - & 4 & - & 0 & 12 & - & 1 \\
\hline Alaska & - & 0 & 4 & 19 & 45 & - & 0 & 0 & - & - & - & 0 & 0 & - & - \\
\hline California & - & 0 & 0 & - & - & - & 0 & 8 & - & 4 & - & 0 & 6 & - & 1 \\
\hline Hawaii & - & 0 & 2 & - & 30 & - & 0 & 0 & - & - & - & 0 & 0 & - & - \\
\hline Oregon & $\mathrm{N}$ & 0 & 0 & $\mathrm{~N}$ & $\mathrm{~N}$ & - & 0 & 1 & - & - & - & 0 & 4 & - & - \\
\hline Washington & $\mathrm{N}$ & 0 & 0 & $\mathrm{~N}$ & $\mathrm{~N}$ & - & 0 & 6 & - & - & - & 0 & 3 & - & - \\
\hline American Samoa & $\mathrm{N}$ & 0 & 0 & $\mathrm{~N}$ & $\mathrm{~N}$ & - & 0 & 0 & - & - & - & 0 & 0 & - & - \\
\hline $\begin{array}{l}\text { C.N.M.I. } \\
\text { (1) }\end{array}$ & - & - & - & - & - & - & - & - & - & - & - & - & - & - & - \\
\hline Guam & - & 0 & 3 & 9 & 14 & - & 0 & 0 & - & - & - & 0 & 0 & - & - \\
\hline Puerto Rico & 4 & 5 & 30 & 146 & 328 & - & 0 & 0 & - & - & - & 0 & 0 & - & - \\
\hline U.S. Virgin Islands & - & 0 & 0 & - & - & - & 0 & 0 & - & - & - & 0 & 0 & - & - \\
\hline
\end{tabular}

C.N.M.I.: Commonwealth of Northern Mariana Islands.

U: Unavailable. - - No reported cases. N: Not reportable. NN: Not Nationally Notifiable. Cum: Cumulative year-to-date counts. Med: Median. Max: Maximum.

* Incidence data for reporting years 2009 and 2010 are provisional. Data for HIV/AIDS, AIDS, and TB, when available, are displayed in Table IV, which appears quarterly.

† Updated weekly from reports to the Division of Vector-Borne Infectious Diseases, National Center for Zoonotic, Vector-Borne, and Enteric Diseases (ArboNET Surveillance). Data for California serogroup, eastern equine, Powassan, St. Louis, and western equine diseases are available in Table I.

$\S$ Contains data reported through the National Electronic Disease Surveillance System (NEDSS).

I Not reportable in all states. Data from states where the condition is not reportable are excluded from this table, except starting in 2007 for the domestic arboviral diseases and influenzaassociated pediatric mortality, and in 2003 for SARS-CoV. Reporting exceptions are available at http://www.cdc.gov/ncphi/disss/nndss/phs/infdis.htm. 
TABLE III. Deaths in 122 U.S. cities, * week ending July 3, 2010 (26th week)

\begin{tabular}{|c|c|c|c|c|c|c|c|c|c|c|c|c|c|c|c|}
\hline \multirow[b]{2}{*}{ Reporting area } & \multicolumn{6}{|c|}{ All causes, by age (years) } & \multirow[b]{2}{*}{$\begin{array}{l}\text { P\&I }{ }^{\dagger} \\
\text { Total }\end{array}$} & \multirow[b]{2}{*}{ Reporting area } & \multicolumn{6}{|c|}{ All causes, by age (years) } & \multirow[b]{2}{*}{$\begin{array}{l}\text { P\& }\left.\right|^{\dagger} \\
\text { Totat }\end{array}$} \\
\hline & $\begin{array}{c}\text { All } \\
\text { Ages }\end{array}$ & $\geq 65$ & $45-64$ & $25-44$ & $1-24$ & $<1$ & & & $\begin{array}{c}\text { All } \\
\text { Ages }\end{array}$ & $\geq 65$ & $45-64$ & $25-44$ & $1-24$ & $<1$ & \\
\hline New England & 453 & 284 & 122 & 26 & 5 & 16 & 33 & S. Atlantic & 1,129 & 697 & 302 & 76 & 38 & 15 & 61 \\
\hline Boston, MA & 120 & 64 & 42 & 5 & 3 & 6 & 9 & Atlanta, GA & 148 & 83 & 36 & 16 & 11 & 2 & 11 \\
\hline Bridgeport, CT & 38 & 25 & 8 & 3 & 1 & 1 & 3 & Baltimore, MD & 150 & 85 & 47 & 10 & 6 & 2 & 10 \\
\hline Cambridge, MA & 13 & 10 & 2 & 1 & - & - & 2 & Charlotte, NC & 97 & 67 & 21 & 6 & 3 & - & 8 \\
\hline Fall River, MA & 17 & 12 & 4 & 1 & - & - & 2 & Jacksonville, FL & 151 & 98 & 40 & 8 & 3 & 2 & 8 \\
\hline Hartford, CT & 46 & 29 & 10 & 2 & - & 5 & 2 & Miami, FL & 106 & 75 & 20 & 9 & 1 & - & 2 \\
\hline Lowell, MA & 14 & 10 & 2 & 2 & - & - & - & Norfolk, VA & 39 & 23 & 13 & 2 & - & 1 & - \\
\hline Lynn, MA & 8 & 5 & 2 & 1 & - & - & - & Richmond, VA & 61 & 38 & 19 & 3 & - & 1 & 4 \\
\hline New Bedford, MA & 16 & 12 & 3 & 1 & - & - & 1 & Savannah, GA & 47 & 31 & 13 & 1 & 1 & 1 & 2 \\
\hline New Haven, CT & 18 & 14 & 3 & 1 & - & - & - & St. Petersburg, FL & 38 & 20 & 11 & 6 & 1 & - & 3 \\
\hline Providence, RI & 55 & 37 & 12 & 3 & 1 & 2 & 1 & Tampa, FL & 185 & 118 & 50 & 9 & 6 & 2 & 4 \\
\hline Somerville, MA & u & u & u & u & u & $\bar{u}$ & u & Washington, D.C. & 90 & 48 & 28 & 4 & 6 & 4 & 9 \\
\hline Springfield, MA & 33 & 20 & 8 & 3 & - & 2 & 3 & Wilmington, $\mathrm{DE}$ & 17 & 11 & 4 & 2 & - & - & - \\
\hline Waterbury, CT & 23 & 16 & 6 & 1 & - & - & 2 & E.S. Central & 953 & 609 & 250 & 56 & 14 & 24 & 87 \\
\hline Worcester, MA & 52 & 30 & 20 & 2 & - & - & 8 & Birmingham, AL & 183 & 115 & 53 & 8 & 3 & 4 & 22 \\
\hline Mid. Atlantic & 1,615 & 1,079 & 372 & 93 & 42 & 29 & 75 & Chattanooga, TN & 86 & 55 & 23 & 6 & 2 & - & 7 \\
\hline Albany, NY & 43 & 26 & 9 & 2 & 5 & 1 & 2 & Knoxville, TN & 108 & 66 & 31 & 10 & - & 1 & 7 \\
\hline Allentown, PA & 31 & 27 & 1 & 2 & 1 & - & 3 & Lexington, KY & 69 & 42 & 17 & 5 & - & 5 & 5 \\
\hline Buffalo, NY & 73 & 54 & 10 & 4 & 2 & 3 & 4 & Memphis, TN & 189 & 115 & 52 & 13 & 5 & 4 & 23 \\
\hline Camden, NJ & 6 & 5 & 1 & - & - & - & - & Mobile, AL & 102 & 72 & 24 & 4 & 1 & 1 & 6 \\
\hline Elizabeth, NJ & 20 & 12 & 6 & 1 & 1 & - & 1 & Montgomery, AL & 68 & 51 & 12 & 3 & 1 & 1 & 11 \\
\hline Erie, PA & u & u & u & u & u & U & u & Nashville, TN & 148 & 93 & 38 & 7 & 2 & 8 & 6 \\
\hline Jersey City, NJ & 20 & 12 & 7 & - & 1 & - & 1 & W.S. Central & 974 & 621 & 230 & 62 & 33 & 28 & 47 \\
\hline New York City, NY & 958 & 652 & 215 & 50 & 21 & 20 & 43 & Austin, TX & 82 & 45 & 21 & 5 & 4 & 7 & 1 \\
\hline Newark, NJ & 32 & 14 & 10 & 6 & 2 & - & 2 & Baton Rouge, LA & 62 & 43 & 7 & 9 & 2 & 1 & - \\
\hline Paterson, NJ & U & u & u & u & $u$ & U & u & Corpus Christi, TX & U & U & U & U & u & u & u \\
\hline Philadelphia, PA & 145 & 89 & 43 & 7 & 3 & 3 & 6 & Dallas, TX & 185 & 109 & 47 & 18 & 7 & 4 & 9 \\
\hline Pittsburgh, $\mathrm{PA}^{\S}$ & 23 & 17 & 6 & - & - & - & - & El Paso, TX & 79 & 53 & 15 & 7 & 2 & 2 & 1 \\
\hline Reading, PA & 32 & 25 & 3 & 4 & - & - & 2 & Fort Worth, TX & U & U & u & u & u & U & U \\
\hline Rochester, NY & 72 & 45 & 18 & 5 & 3 & 1 & 3 & Houston, TX & 159 & 98 & 42 & 4 & 5 & 10 & 9 \\
\hline Schenectady, NY & 26 & 17 & 7 & 1 & 1 & - & 1 & Little Rock, AR & u & U & u & u & u & u & $u$ \\
\hline Scranton, PA & 24 & 18 & 3 & 2 & - & 1 & 2 & New Orleans, LA & U & U & U & U & $\mathrm{u}$ & $\mathrm{u}$ & u \\
\hline Syracuse, NY & 51 & 28 & 19 & 3 & 1 & - & 1 & San Antonio, TX & 259 & 168 & 67 & 15 & 7 & 2 & 16 \\
\hline Trenton, NJ & 32 & 19 & 9 & 3 & 1 & - & 1 & Shreveport, LA & 49 & 31 & 15 & 1 & - & 2 & 3 \\
\hline Utica, NY & 8 & 6 & 1 & 1 & - & - & 2 & Tulsa, OK & 99 & 74 & 16 & 3 & 6 & - & 8 \\
\hline Yonkers, NY & 19 & 13 & 4 & 2 & - & - & 1 & Mountain & 1,052 & 690 & 241 & 76 & 25 & 18 & 73 \\
\hline E.N.Central & 1,728 & 1,104 & 435 & 110 & 44 & 35 & 118 & Albuquerque, NM & 113 & 72 & 28 & 7 & 2 & 4 & 9 \\
\hline Akron, $\mathrm{OH}$ & 3 & 3 & - & - & - & - & 3 & Boise, ID & 42 & 29 & 7 & 5 & 1 & - & 4 \\
\hline Canton, $\mathrm{OH}$ & 28 & 16 & 8 & 2 & 1 & 1 & 2 & Colorado Springs, CO & 73 & 55 & 13 & 4 & - & 1 & 1 \\
\hline Chicago, IL & 234 & 134 & 67 & 23 & 9 & 1 & 15 & Denver, CO & 65 & 45 & 13 & 3 & 2 & 2 & 4 \\
\hline Cincinnati, $\mathrm{OH}$ & 91 & 56 & 24 & 7 & 2 & 2 & 10 & Las Vegas, NV & 261 & 168 & 75 & 13 & 3 & - & 21 \\
\hline Cleveland, $\mathrm{OH}$ & 187 & 120 & 50 & 8 & 2 & 7 & 8 & Ogden, UT & 36 & 29 & 2 & - & 5 & - & 4 \\
\hline Columbus, $\mathrm{OH}$ & 136 & 79 & 36 & 10 & 5 & 6 & 14 & Phoenix, AZ & 171 & 108 & 42 & 12 & 4 & 5 & 10 \\
\hline Dayton, $\mathrm{OH}$ & 150 & 102 & 31 & 10 & 7 & - & 19 & Pueblo, CO & 21 & 12 & 6 & 3 & - & - & 2 \\
\hline Detroit, Ml & 115 & 64 & 37 & 7 & 5 & 2 & 2 & Salt Lake City, UT & 129 & 80 & 23 & 16 & 5 & 5 & 8 \\
\hline Evansville, IN & 37 & 26 & 10 & 1 & - & - & 2 & Tucson, AZ & 141 & 92 & 32 & 13 & 3 & 1 & 10 \\
\hline Fort Wayne, IN & 60 & 40 & 17 & 3 & - & - & 6 & Pacific & 1,431 & 981 & 310 & 86 & 27 & 27 & 124 \\
\hline Gary, IN & 16 & 9 & 5 & 2 & - & - & 2 & Berkeley, CA & 14 & 7 & 5 & 2 & - & - & 1 \\
\hline Grand Rapids, Ml & 55 & 42 & 7 & 1 & 1 & 4 & 2 & Fresno, CA & 131 & 87 & 32 & 7 & 3 & 2 & 17 \\
\hline Indianapolis, IN & 200 & 120 & 51 & 15 & 8 & 6 & 15 & Glendale, CA & 32 & 29 & 2 & 1 & - & - & 6 \\
\hline Lansing, MI & 38 & 29 & 6 & 2 & 1 & - & 1 & Honolulu, HI & 62 & 48 & 8 & 2 & 3 & 1 & 9 \\
\hline Milwaukee, WI & 50 & 29 & 18 & 3 & - & - & 3 & Long Beach, CA & 67 & 40 & 23 & 4 & - & - & 6 \\
\hline Peoria, IL & 47 & 36 & 8 & 1 & 1 & 1 & 4 & Los Angeles, CA & 254 & 163 & 56 & 23 & 7 & 5 & 19 \\
\hline Rockford, IL & 53 & 33 & 12 & 4 & 1 & 3 & 2 & Pasadena, CA & 15 & 11 & 4 & - & - & - & 1 \\
\hline South Bend, IN & 56 & 39 & 10 & 6 & - & 1 & 2 & Portland, OR & 99 & 71 & 20 & 3 & - & 5 & 4 \\
\hline Toledo, $\mathrm{OH}$ & 91 & 65 & 23 & 3 & - & - & 3 & Sacramento, CA & 175 & 114 & 41 & 16 & 4 & - & 16 \\
\hline Youngstown, $\mathrm{OH}$ & 81 & 62 & 15 & 2 & 1 & 1 & 3 & San Diego, CA & 147 & 112 & 26 & 5 & 2 & 2 & 11 \\
\hline W.N. Central & 819 & 529 & 195 & 42 & 23 & 29 & 48 & San Francisco, CA & 97 & 66 & 19 & 5 & 3 & 4 & 11 \\
\hline Des Moines, IA & 150 & 104 & 28 & 8 & 5 & 5 & 7 & San Jose, CA & 174 & 125 & 37 & 7 & 2 & 3 & 12 \\
\hline Duluth, MN & 25 & 16 & 9 & - & - & - & 2 & Santa Cruz, CA & 29 & 19 & 9 & - & - & 1 & 1 \\
\hline Kansas City, KS & 30 & 18 & 10 & 2 & - & - & 3 & Seattle, WA & 85 & 57 & 18 & 7 & 1 & 2 & 8 \\
\hline Kansas City, MO & 93 & 59 & 23 & 5 & 3 & 2 & 2 & Spokane, WA & 50 & 32 & 10 & 4 & 2 & 2 & 3 \\
\hline Lincoln, NE & 59 & 45 & 8 & 3 & 1 & 2 & 7 & Tacoma, WA & U & U & u & u & U & U & U \\
\hline Minneapolis, MN & 61 & 37 & 15 & 7 & 1 & 1 & 3 & Total" & 10,154 & 6,594 & 2,457 & 627 & 251 & 221 & 667 \\
\hline Omaha, NE & 86 & 55 & 21 & 2 & 2 & 6 & 4 & & & & & & & & \\
\hline St. Louis, MO & 197 & 116 & 54 & 10 & 7 & 10 & 12 & & & & & & & & \\
\hline St. Paul, MN & 42 & 29 & 9 & 2 & 2 & - & 4 & & & & & & & & \\
\hline Wichita, KS & 76 & 50 & 18 & 3 & 2 & 3 & 4 & & & & & & & & \\
\hline
\end{tabular}

U: Unavailable. - No reported cases.

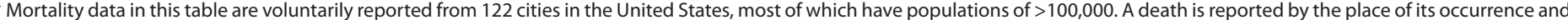
by the week that the death certificate was filed. Fetal deaths are not included.

† Pneumonia and influenza.

$\S$ Because of changes in reporting methods in this Pennsylvania city, these numbers are partial counts for the current week. Complete counts will be available in 4 to 6 weeks.

" Total includes unknown ages. 


The Morbidity and Mortality Weekly Report (MMWR) Series is prepared by the Centers for Disease Control and Prevention (CDC) and is available free of charge in electronic format. To receive an electronic copy each week, visit $M M W R$ 's free subscription page at http://www.cdc.gov/mmwr/mmwrsubscribe.html. Paper copy subscriptions are available through the Superintendent of Documents, U.S. Government Printing Office, Washington, DC 20402; telephone 202-512-1800.

Data presented by the Notifiable Disease Data Team and 122 Cities Mortality Data Team in the weekly $M M W R$ are provisional, based on weekly reports to CDC by state health departments. Address all inquiries about the $M M W R$ Series, including material to be considered for publication, to Editor, $M M W R$ Series, Mailstop E-90, CDC, 1600 Clifton Rd., N.E., Atlanta, GA 30333 or to mmwrq@cdc.gov.

All material in the MMWR Series is in the public domain and may be used and reprinted without permission; citation as to source, however, is appreciated.

Use of trade names and commercial sources is for identification only and does not imply endorsement by the U.S. Department of Health and Human Services.

References to non-CDC sites on the Internet are provided as a service to $M M W R$ readers and do not constitute or imply endorsement of these organizations or their programs by CDC or the U.S. Department of Health and Human Services. CDC is not responsible for the content of these sites. URL addresses listed in MMWR were current as of the date of publication.

论 U.S. Government Printing Office: 2010-623-026/41260 Region IV ISSN: 0149-2195 